\title{
CLASSIFICATION OF SPECIES OF EBOLA- VIRUS, BASED ON THE PHYSICO-CHEMICAL- PROPERTIES, CONSERVED AMINO-ACIDS, GENE-STRUCTURAL INFORMATION AND INTERPRETING ITS SIGNIFICANCE
}

\author{
Divya Peddapalyam \\ Msc. Biotechnology \\ Garden City University \\ Bengaluru, Karnataka, India
}

\author{
Reetika Mishra \\ Msc. Biotechnology \\ Garden City University \\ Bengaluru, Karnataka, India
}

\author{
Dr. Madhu Malleshappa \\ Msc, PhD,Post-Doc \\ Garden city University \\ Bengaluru, Karnataka, India
}

\begin{abstract}
Ebola Infection malady ia an uncommon and Destructive ailment which for the most part two people And non human primates, for example monkeys, gorillas, Chimpanzees. Among the five types of species i.e; Zaire, Sudan, Taiforest, Bundibugyo impacts the people and Reston Ebola virus known to cause disease in non human Primates and pigs. This Ebola infection was first found in 1976 close to ebola water way in majority rule republic Of congo.For Ebola virus sickness casuality rate is $90 \%$. 318 individuals tainted and 280 passings are brought About by this infection with death pace of $88 \%$.
\end{abstract}

\section{OBJECTIVES}

The extensive target of the subsequent module is that to create a compact, data rich outline of grouping information., illustrate the disparity between a gathering of sequences, Usage of arrangements as models to test hyphothesis, as well as to know whether this model of occasions precisely reflect known organic proof. The primary goal of the third module is to comprehend the essential ideas in quality finding, for example, relationship of protein and nucleotide groupings/exons/introns/coding arrangements/open perusing outlines/agreement properties of exon-intron fringes. Novel highlights of the program incorporate the ability to anticipate different qualities in a succession, to manage fractional just as complete qualities, and to foresee steady arrangements of qualities happening on either or both DNA strands. In the enormous scale investigation of gene, the regular procedure is totally inactivate every quality or over express it. In each case coming about phenotype may not be instructive. The loss of numerous proteins is deadly and this reveals to us that protein is fundamental however donot determine what protein really does. After forecast of quality structure, related with this protein we can research its Structure, Function, diseases, mutations and by utilizing this data we can fix numerous diseases. It utilizes factual example recognizable proof and succession similitude comparision, in which first technique utilizes every single imaginable ways to deal with concentrate the quality structure which incorporates advertiser region, start and end arrangements of intron and exon. As the closeness depends on the evolution, either our grouping is homologous or not, this procedure depends on the comparability which exploit on the way that if the succession is similar, it will have a similar capacity.

\section{METHODOLOGY}

ProtParam registers different physico-substance properties that can be reasoned from a protein succession. No extra data is required about the protein under thought. The protein can either be indicated as a Swiss-Prot/TrEMBL promotion number or ID, or in type of a crude arrangement. Blank area and numbers are disregarded. In the event that you give the promotion number of a Swiss-Prot/TrEMBL passage, you will be incited with a delegate page that enables you to choose the part of the succession on which you might want to play out the investigation. The decision incorporates a choice of develop chains or peptides and spaces from the Swiss-Prot highlight table (which can be picked by tapping on the situations), just as the likelihood to enter start and end position in two boxes.

\section{EXTINCTION COEFFICIENT}

The Extinction coefficient shows how much light a protein assimilates at a specific wavelength. It is helpful to have an estimation of this coefficient for following a protein which a spectrophotometer when filtering it. It is conceivable to assess the molar Extinction coefficient of a protein from information of its amino corrosive creation. From the molar extinction coefficient of tyrosine, tryptophan, and cystine (cysteine doesn't ingest considerably at wavelengths $>260 \mathrm{~nm}$, while cystine does) at a given wavelength, the termination coefficient of a denatured protein can be figured. Two tables are delivered by ProtParam, the first demonstrating the processed qualities dependent on the supposition that all cysteine deposits show up as half cystines, and the subsequent one accepting that no cysteine shows up as half cystine. Formula for calculating Extinction coefficient is given below.

$\mathrm{E}($ Prot $)=\operatorname{Numb}($ Tyr $) * \operatorname{Ext}($ Tyr $)+\operatorname{Numb}(\operatorname{Trp}) * \operatorname{Ext}(\operatorname{Trp})+$

Numb(Cystine)*Ext(Cystine)

$\operatorname{Ext}(\mathrm{Tyr})=1490$,

$\operatorname{Ext}(\operatorname{Trp})=5500$

$\operatorname{Ext}($ Cystine $)=125$; 


\section{ALIPHATIC INDEX}

The Aliphatic list of a protein is characterized as the relative volume involved by aliphatic side chains (alanine, valine, isoleucine, and leucine). It might be viewed as a positive factor for the expansion of thermostability of globular proteins

Aliphatic index $=\mathrm{X}($ Ala $)+\mathrm{a} * \mathrm{X}(\mathrm{Val})+\mathrm{b} *(\mathrm{X}(\mathrm{Ile})+\mathrm{X}(\mathrm{Leu})$

Where,

$\mathrm{X}($ Ala $)=$ Mole percent of Alanine

$\mathrm{X}(\mathrm{Val})=$ Mole percent of valine

$\mathrm{X}($ Ile $)=$ Mole percent of Isoleucine

$\mathrm{X}(\mathrm{Leu})=$ Mole percent of leucine

\section{GRAND AVERAGE OF HYDROPHATICITY}

The Grand Average of hydropathy (GRAVY) esteem for a peptide or protein is determined as the entirety of hydropathy estimations of all the amino acids, isolated by the number of deposits in the succession

\section{INVIVO HALF-LIFE}

The half-life is an expectation of the time it takes for half of the measure of protein in a cell to vanish after its blend in the cell. The expectation is given for three creatures (human, yeast, and E. coli), yet it is conceivable to extrapolate the outcome to comparative living beings. ProtParam gauges the half-life by taking a gander at the Nterminal amino corrosive of the grouping under investigation.

\section{INSTABILTY INDEX}

\#' @export instaIndex

\#' @ title Compute the instability index of a protein sequence

\#' @ description This function calculates the instability index proposed by Guruprasad (1990). This index predicts the stability of a protein based on its amino acid composition, a protein whose instability index is smaller than 40 is predicted as stable, a value above 40 predicts that the protein may be unstable.

\#' @ param seq An amino-acids sequence

\#' @return The computed instability index for a given amino-acids sequence

\#' @ references Guruprasad K, Reddy BV, Pandit MW

(1990). "Correlation between stability of a protein and its dipeptide composition: a novel approach for predicting in vivo stability of a protein from its primary sequence".

Protein Eng. 4 (2): 155 - 61. doi:10.1093/protein/4.2.155

\#' @examples

\#' \# COMPARED TO ExPASy INSTAINDEX

\#' \# http://web.expasy.org/protparam/

\#' \# SEQUENCE:

QWGRRCCGWGPGRRYCVRWC

83.68 \#' \# The instability index (II) is computed to be

\footnotetext{
\#' \#' instaIndex(seq

"QWGRRCCGWGPGRRYCVRWC") \#' \# [1] 83.68
}

\section{\#'}

instaIndex <- function(seq) \{ \# Setting the Guruprasad scale guruprasad <-

c(

$\mathrm{WW}=1$,

$\mathrm{WC}=1$,

$\mathrm{WM}=24.68$,

$\mathrm{WH}=24.68$,

$\mathrm{WY}=1$,

$\mathrm{WF}=1$,

$\mathrm{WQ}=1$,

$\mathrm{WN}=13.34$,

$\mathrm{WI}=1$,

$\mathrm{WR}=1$,

$\mathrm{WD}=1$,

$\mathrm{WP}=1$,

$\mathrm{WT}=-14.03$,

$\mathrm{WK}=1$,

$\mathrm{WE}=1$,

$\mathrm{WV}=-7.49$,

$\mathrm{WS}=1$,

$\mathrm{WG}=-9.37$,

$\mathrm{WA}=-14.03$,

$\mathrm{WL}=13.34$,

$\mathrm{CW}=24.68$,

$\mathrm{CC}=1$,

$\mathrm{CM}=33.6$,

$\mathrm{CH}=33.6$,

$\mathrm{CY}=1$,

$\mathrm{CF}=1$,

$\mathrm{CQ}=-6.54$,

$\mathrm{CN}=1$,

$\mathrm{CI}=1$,

$\mathrm{CR}=1$,

$\mathrm{CD}=20.26$,

$\mathrm{CP}=20.26$,

$\mathrm{CT}=33.6$,

$\mathrm{CK}=1$,

$\mathrm{CE}=1$,

$\mathrm{CV}=-6.54$,

$\mathrm{CS}=1$,

$\mathrm{CG}=1$,

$\mathrm{CA}=1$,

$\mathrm{CL}=20.26$,

$\mathrm{MW}=1$,

$\mathrm{MC}=1$,

$\mathrm{MM}=-1.88$,

$\mathrm{MH}=58.28$,

$\mathrm{MY}=24.68$,

$\mathrm{MF}=1$,

$\mathrm{MQ}=-6.54$,

$\mathrm{MN}=1$,

$\mathrm{MI}=1$,

$\mathrm{MR}=-6.54$,

$\mathrm{MD}=1$,

$\mathrm{MP}=44.94$,

$\mathrm{MT}=-1.88$,

$\mathrm{MK}=1$,

$\mathrm{ME}=1$,

$\mathrm{MV}=1$, 
Published Online January 2020 in IJEAST (http://www.ijeast.com)

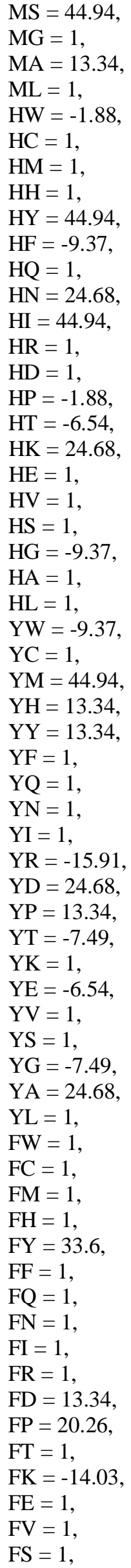

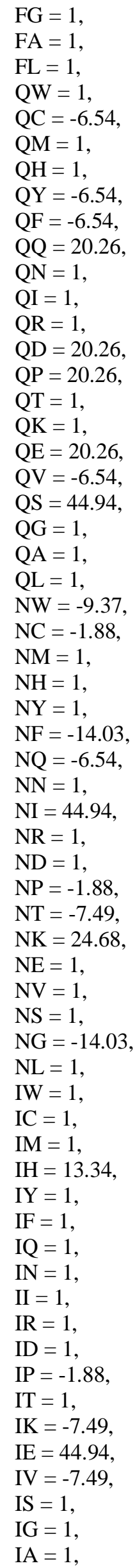


Published Online January 2020 in IJEAST (http://www.ijeast.com)

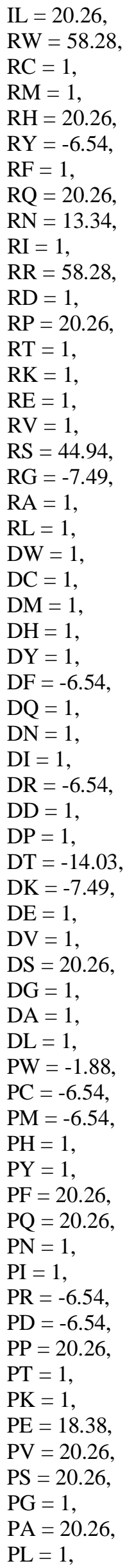

$$
\begin{aligned}
& \mathrm{TW}=-14.03 \text {, } \\
& \mathrm{TC}=1 \text {, } \\
& \mathrm{TM}=1 \text {, } \\
& \mathrm{TH}=1 \text {, } \\
& \mathrm{TY}=1 \text {, } \\
& \mathrm{TF}=13.34 \text {, } \\
& \mathrm{TQ}=-6.54 \text {, } \\
& \mathrm{TN}=-14.03 \text {, } \\
& \mathrm{TI}=1 \text {, } \\
& \mathrm{TR}=1 \text {, } \\
& \mathrm{TD}=1 \text {, } \\
& \mathrm{TP}=1 \text {, } \\
& \mathrm{TT}=1 \text {, } \\
& \mathrm{TK}=1 \text {, } \\
& \mathrm{TE}=20.26 \text {, } \\
& \mathrm{TV}=1 \text {, } \\
& \mathrm{TS}=1 \text {, } \\
& \mathrm{TG}=-7.49 \text {, } \\
& \mathrm{TA}=1 \text {, } \\
& \mathrm{TL}=1 \text {, } \\
& \mathrm{KW}=1 \text {, } \\
& \mathrm{KC}=1 \text {, } \\
& \mathrm{KM}=33.6 \text {, } \\
& \mathrm{KH}=1 \text {, } \\
& \mathrm{KY}=1 \text {, } \\
& \mathrm{KF}=1 \text {, } \\
& \mathrm{KQ}=24.68 \text {, } \\
& \mathrm{KN}=1 \text {, } \\
& \mathrm{KI}=-7.49 \text {, } \\
& \mathrm{KR}=33.6 \text {, } \\
& \mathrm{KD}=1 \text {, } \\
& \mathrm{KP}=-6.54 \text {, } \\
& \mathrm{KT}=1 \text {, } \\
& \mathrm{KK}=1 \text {, } \\
& \mathrm{KE}=1 \text {, } \\
& \mathrm{KV}=-7.49 \text {, } \\
& \mathrm{KS}=1 \text {, } \\
& \mathrm{KG}=-7.49 \text {, } \\
& \mathrm{KA}=1 \text {, } \\
& \mathrm{KL}=-7.49 \text {, } \\
& \mathrm{EW}=-14.03 \text {, } \\
& \mathrm{EC}=44.94 \text {, } \\
& \mathrm{EM}=1 \text {, } \\
& \mathrm{EH}=-6.54 \text {, } \\
& \mathrm{EY}=1 \text {, } \\
& \mathrm{EF}=1 \text {, } \\
& \mathrm{EQ}=20.26 \text {, } \\
& \mathrm{EN}=1 \text {, } \\
& \mathrm{EI}=20.26 \text {, } \\
& \mathrm{ER}=1 \text {, } \\
& \mathrm{ED}=20.26 \text {, } \\
& \mathrm{EP}=20.26 \text {, } \\
& \mathrm{ET}=1 \text {, } \\
& \mathrm{EK}=1 \text {, } \\
& \mathrm{EE}=33.6 \text {, } \\
& \mathrm{EV}=1 \text {, } \\
& \mathrm{ES}=20.26 \text {, } \\
& \mathrm{EG}=1 \text {, } \\
& \mathrm{EA}=1 \text {, } \\
& \mathrm{EL}=1 \text {, } \\
& \mathrm{VW}=1 \text {, }
\end{aligned}
$$




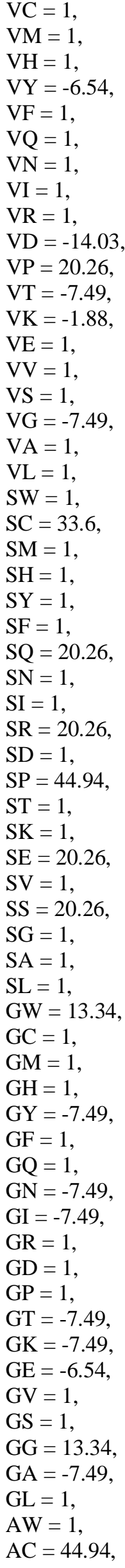

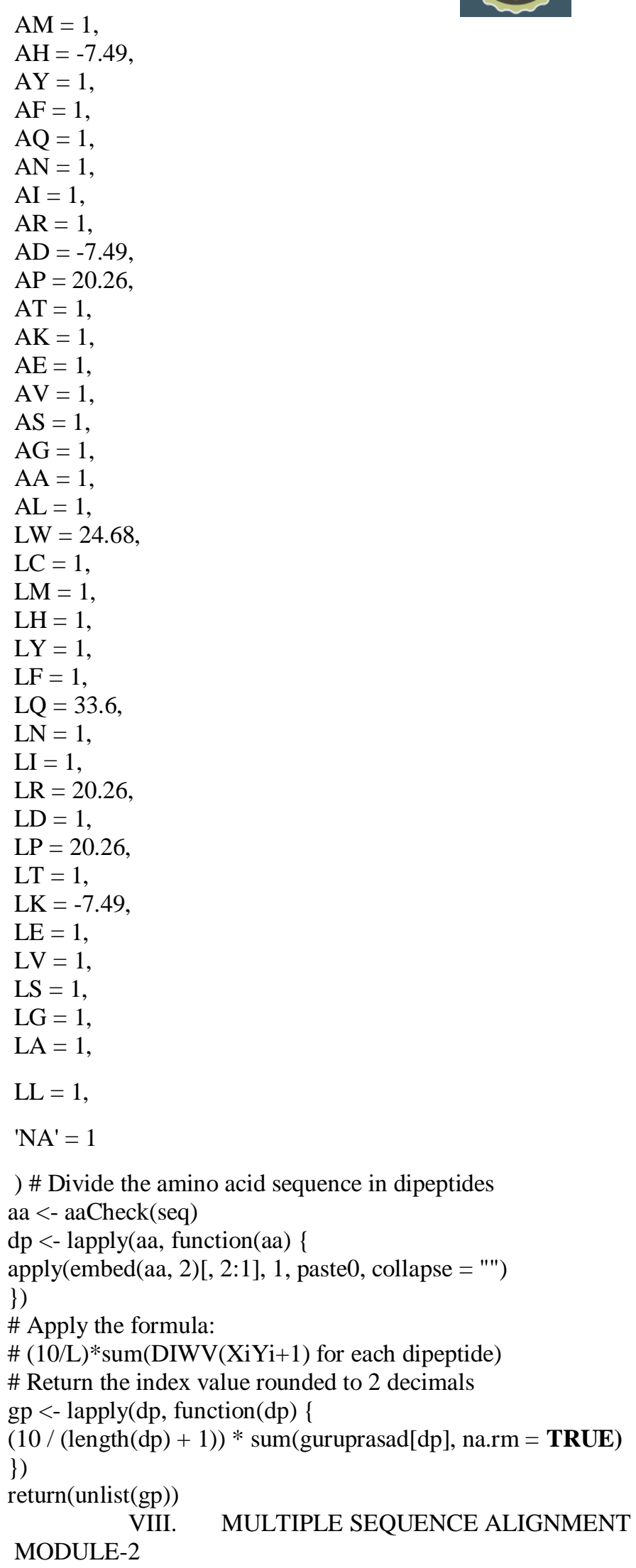

We care about the grouping arrangements in the computational science since it gives scientists helpful data about various viewpoints. For instance, it can educate us regarding the advancement of the living beings, we can see which locales of a quality (or its determined protein) are defenseless to change and which can have one buildup supplanted by another without evolving capacity, we can think about Homologous 
qualities and can reveal paralogs and Orthologs qualities that are developmental related. In issues, for example, the development of a transformative tree dependent on arrangement information, or in protein designing, where a different arrangement of related groupings may regularly yield the most supportive data on the plan of another protein, an atomic scholar must think about multiple arrangements all the while. A numerous grouping arrangement (MSA) organizes protein successions into a rectangular exhibit with the objective that buildups in a given section are homologous (gotten from a single situation in a hereditary grouping), superposable (in an unbending nearby basic arrangement) or assume a typical practical job. In spite of the fact that these three criteria are basically comparable for firmly related proteins, arrangement, structure and capacity separate over transformative time and various criteria may bring about various arrangements. Physically refined arrangements keep on being better than simply mechanized techniques; there is in this manner a persistent exertion to improve the organic exactness of MSA apparatuses. Also, the high computational expense of most guileless calculations inspires upgrades in speed and memory utilization to suit the quick increment in accessible succession information. The ClustalW calculation has three Important Phases. They are

Stage I: All sets of arrangements are adjusted independently ascertain a Distance Matrix dependent on the level of befuddles each pair of groupings.

Stage II: The guide tree is developed from the separation framework utilizing the Neighbor Joining calculation.

Stage III: The successions are dynamically adjusted after the guide tree.

\section{MODULE-3}

Genscan is utilized for anticipating the areas and exon-intron structures of qualities in genomic groupings from an assortment of creatures. This server can acknowledge arrangements up to 1 million base sets (1 Mbp) long. On the off chance that you experience difficulty with the web server or on the off chance that you have an enormous number of groupings to process, demand a nearby duplicate of the program.OMICS _01494 was created by Chris Burge in the examination gathering of Samuel Karlin, Department of Mathematics, Stanford University.OMICS_10494 is uninhibitedly accessible for scholastic use. Executables are right now accessible for the accompanying Unix stages: Intel/Linux, Sun/Solaris, Intel/Solaris, SGI/Irix, DEC/Tru64, and IBM/AIX.Distinguishes total exon/intron structures of qualities in genomic DNA. OMICS_01494 utilizes a homogeneous fifth request Markov model of noncoding areas and a three intermittent (inhomogeneous) fifth request Markov model of coding districts. Highlights of the program incorporate the ability to foresee various qualities in a grouping, to manage halfway just as complete qualities, and to anticipate predictable arrangements of qualities happening on either or both DNA strands

\section{LITERATURE REVIEW}

Ebolavirus has a place with the request Mononegavirales and the family Filoviridae.Its RNA genome encodes the accompanying 9 protein items: Spike glycoprotein (GP), Small secreted glycol-protein,Second secreted Glycoprotein,Nucleoprotein (NP), RNA-subordinate RNA polymerase (L), Membrane-related protein (VP24), Minor nucleoprotein (VP30), Polymerase cofactor (VP35), and Matrix protein (VP40). The GP transcript can be altered, and the quality item can be handled by host protease, offering ascend to 4 elective types of quality items: GP1,2; GP1,2delta; sGP and ssGP. furin can sever the longest item interpreted from altered GP mRNA and create GP1,2, which comprises of 2 peptide chains associated by a disulfide bond, GP1 and GP2. GP1,2 is gathered on the layer of Ebolavirus and intercedes cell passage. GP1,2delta is the handled item after evacuation of the C-terminal transmembrane locale of GP1,2 by host ADAM17. Different results of the GP quality, sGP and ssGP are interpreted from the unedited mRNA and then again altered mRNA, respectively.These items share the $\mathrm{N}$-terminal 295 buildups with GP1,2, however vary in their short tails (69 and 3 deposits, separately). GP1,2delta, sGP and ssGP may keep the killing antibodies from restricting GP1,2 on the infection surface, adding to the insusceptible avoidance of the infection. Not withstanding filling in as basic parts, the Ebolavirus proteins assume numerous jobs in the infection life cycle. GP intercedes cell section and layer combination between the infection and the host cell. NP encapsidates the genome and shields it from nucleases.VP30 is a translation hostile to eliminator and directs the switch among interpretation and replication.VP35 goes about as a cofactor of the polymerase, and VP40 may likewise assume a job in genome replication and interpretation. VP24 and VP35 take an interest in viral nucleocapsid assembly,and VP40 is basic for infection growing and gathering. What's more, GP, VP24, VP30, VP35 and VP40 associate with different host proteins to finish the viral life cycle and to stifle the host insusceptible reaction. In the present examination, we anticipate the 3D structure and utilitarian locales for Ebolavirus protein areas that are not yet portrayed. Also, we think about successions of Ebolavirus proteins' communicating accomplices from RESTV-safe primates with those from RESTV-powerless monkeys. Raised arrangement difference for GP and VP35's collaboration accomplices recommends that these 2 viral proteins might be in charge of host particularity in RESTV. At last, we think about the protein groupings from various Ebolavirus species to distinguish places that are moderated among human pathogenic species yet extraordinary in nonpathogenic (RESTV-explicit transformations). Mapping of these RESTV-explicit transformations and known utilitarian destinations to the 3D structures uncovers bunches of RESTV-explicit changes on the surfaces of GP, VP35 and VP24. These bunches don't cover with the known useful locales and may propose novel connection destinations with host proteins.Based on this review we decided to study physicochemical protperties of Ebolavirus along with Gene structural information and sequence homology to interpret significant aspects on Ebola virus. Ebola Virus Disease (EVD) is a rare and deadly disease in people and nonhuman primates. The viruses that cause EVD are located mainly in sub-Saharan Africa. People can get EVD through direct contact with an infected animal (bat or nonhuman primate) or a sick or dead person infected with Ebola virus.The U.S. Food and Drug Administration (FDA) has approved the Ebola vaccine rVSV-ZEBOV (tradename "Ervebo") for the prevention of EVD. The rVSV-ZEBOV vaccine has been found to be safe and protective against only the Zaire ebolavirus species of ebolavirus. Ebola virus disease (EVD), one of the deadliest viral diseases, was discovered in 1976 when two consecutive outbreaks of fatal hemorrhagic fever occurred in different parts of Central Africa. The first outbreak occurred in the Democratic Republic of Congo (formerly Zaire) in a village near the Ebola River, which gave the virus its name. The second outbreak occurred in what is now South Sudan, approximately 500 miles $(850 \mathrm{~km})$ away.Initially, public health officials assumed these outbreaks were a single event associated with an infected person who traveled between the two locations. However, scientists later discovered that the two outbreaks were caused by two genetically distinct viruses: Zaire ebolavirus and Sudan ebolavirus. After this discovery, scientists concluded that the virus came from two 
different sources and spread independently to people in each of the affected areas.Viral and epidemiologic data suggest that Ebola virus existed long before these recorded outbreaks occurred. Factors like population growth, encroachment into forested areas, and direct interaction with wildlife (such as bushmeat consumption) may have contributed to the spread of the Ebola virus. Following the discovery of the virus, scientists studied thousands of animals, insects, and plants in search of its source (called reservoir among virologists, people who study viruses). Gorillas, chimpanzees, and other mammals may be implicated when the first cases of an EVD outbreak in people occur. However, they - like people - are "dead-end" hosts, meaning the organism dies following the infection and does not survive and spread the virus to other animals. Like other viruses of its kind, it is possible that the reservoir host animal of Ebola virus does not experience acute illness despite the virus being present in its organs, tissues, and blood. Thus, the virus is likely maintained in the environment by spreading from host to host or through intermediate hosts or vectors.African fruit bats are likely involved in the spread of Ebola virus and may even be the source animal (reservoir host). Scientists continue to search for conclusive evidence of the bat's role in transmission of Ebola. The most recent Ebola virus to be detected, Bombali virus, was identified in samples from bats collected in Sierra Leone. The use of contaminated needles and syringes during the earliest outbreaks enabled transmission and amplification of Ebola virus. During the first outbreak in Zaire (now Democratic Republic of Congo DRC), nurses in the Yambuku mission hospital reportedly used five syringes for 300 to 600 patients a day. Close contact with infected blood, reuse of contaminated needles, and improper nursing techniques were the source for much of the human-tohuman transmission during early Ebola outbreaks.In 1989, Reston ebolavirus was discovered in research monkeys imported from the Philippines into the U.S. Later, scientists confirmed that the virus spread throughout the monkey population through droplets in the air (aerosolized transmission) in the facility. However, such airborne transmission is not proven to be a significant factor in human outbreaks of Ebola.4 The discovery of the Reston virus in these monkeys from the Philippines revealed that Ebola was no longer confined to African settings, but was present in Asia as well.By the 1994 Cote d'Ivoire outbreak, scientists and public health officials had a better understanding of how Ebola virus spreads and progress was made to reduce transmission through the use of face masks, gloves and gowns for healthcare personnel. In addition, the use of disposable equipment, such as needles, was introduced. During the 1995 Kikwit, Zaire (now DRC) outbreak, the international public health community played a strong role, as it was now widely agreed that containment and control of Ebola were paramount. Ebola virus disease (EVD) is a life-threatening viral disease with a fatality rate ranging from around $30 \%$ to $90 \%$. The first EVD outbreak was reported in the 1970s in Zaire (now the Democratic Republic of the Congo). Until 2013, most outbreaks occurred in the Central Africa region, including Zaire, Sudan and Uganda. However, between March and October 2014, over 10000 cases of EVD have been recorded in West Africa, such as in Guinea, Liberia, Sierra Leone, and Nigeria, and a few hospital or secondary infections of EVD have occurred in Spain and the United States of America. EVD is presently one of the world's most feared diseases. In this literature review, we describe the epidemiology, clinical features, diagnosis, and treatment of EVD.
The virus is thought to be initially acquired by exposure to body fluids or tissue from infected animals, such as bats and non-human primates; however, the natural reservoir and mode of transmission to humans has not been confirmed. Laboratory testing of reservoir competence shows that successful infection is possible in bats and rodents, but not in plants or arthropods. Animal to human transmission may occur during hunting and consumption of the reservoir species or infected nonhuman primates. The practice of butchering or eating bush meat or food contaminated with bat faeces (three species of tree roosting bats have been implicated as a reservoir) is also thought to contribute. Human to human transmission occurs through contact with body fluids from infected patients. In early epidemics, the re-use of non-sterile injections was responsible for many healthcare associated transmissions. However, although this remains a risk, most cases result from close physical contact or contact with body fluids (such as sweat, blood, faeces, vomit, saliva, genital secretions, urine, and breast milk) of infected patients. In a study of viral shedding in various body fluids, Ebola virus was isolated from saliva, breast milk, stool, tears, and semen up to 40 days after the onset of illness, confirming the possibility of delayed sexual transmission. Virus may be found in urine during recovery, and the duration of this phenomenon needs further study. Infection through inhalation is possible in non-human primates, but there is no evidence for airborne transmission in humans.Outside endemic areas, Ebola virus infection is rare and is usually imported.Travellers from affected areas, and laboratory scientists and others working with potentially infected materials and animals, are at high

risk. 
International Journal of Engineering Applied Sciences and Technology, 2020

Vol. 4, Issue 9, ISSN No. 2455-2143, Pages 241-271

Published Online January 2020 in IJEAST (http://www.ijeast.com)

\section{RESULTS AND DISCUSSION MODULE-1}

\begin{tabular}{|c|c|c|c|c|c|c|c|}
\hline & & & Bundibugyo Ebola virus & Sudan Ebola virus & Reston Ebola virus & Zaire Ebola virus & Tai forest ebola virus \\
\hline \multirow[t]{2}{*}{$\begin{array}{l}\text { Number and composition of amino } \\
\text { acids }\end{array}$} & Alanine & (Ala) & $63(8.5 \%)$ & $52(7.0 \%)$ & $60(8.1 \%)$ & $53(7.2 \%)$ & $54(7.3 \%)$ \\
\hline & Arginine & (Arg) & $31(4.2 \%)$ & $27(3.7 \%)$ & $39(5.3 \%)$ & $33(4.5 \%)$ & $29(3.9 \%)$ \\
\hline \multirow{18}{*}{ NUCLEO-PROTEN } & Asparagine & (Asn) & $43(5.8 \%)$ & $34(4.6 \%)$ & $40(5.4 \%)$ & $33(4.5 \%)$ & $45(6.1 \%)$ \\
\hline & Aspartic acid & (Asp) & $57(7.7 \%)$ & $59(8.0 \%)$ & $59(8.0 \%)$ & $59(8.0 \%)$ & $48(6.5 \%)$ \\
\hline & Cysteine & (Cys) & $03(0.4 \%)$ & $03(0.4 \%)$ & $03(0.4 \%)$ & $03(0.4 \%)$ & $03(0.4 \%)$ \\
\hline & Glutamine & $(\mathrm{Gln})$ & $51(6.9 \%)$ & $47(6.4 \%)$ & $52(7.0 \%)$ & $53(7.2 \%)$ & $49(6.6 \%)$ \\
\hline & Glutamic acid & (Glu) & $56(7.6 \%)$ & $\mathbf{5 8}(7.9 \%)$ & $\mathbf{5 9}(8.0 \%)$ & $59(8.0 \%)$ & $63(8.5 \%)$ \\
\hline & Glycine & (Gly) & $37(5.0 \%)$ & $53(7.2 \%)$ & $42(5.7 \%)$ & $41(5.5 \%)$ & $37(5.0 \%)$ \\
\hline & Histidine & (His) & $25(3.4 \%)$ & $25(3.4 \%)$ & $28(3.8 \%)$ & $30(4.1 \%)$ & $30(4.1 \%)$ \\
\hline & Iso-Leucine & (Ile) & $38(5.1 \%)$ & $29(3.9 \%)$ & $33(4.5 \%)$ & $29(3.9 \%)$ & $34(4.6 \%)$ \\
\hline & Leucine & (Leu) & $62(8.4 \%)$ & $77(10.4 \%)$ & $74(10.0 \%)$ & $67(9.1 \%)$ & $64(8.7 \%)$ \\
\hline & Lysine & (Lys) & $37(5.0 \%)$ & $36(4.9 \%)$ & $31(4.2 \%)$ & $38(5.1 \%)$ & $41(5.5 \%)$ \\
\hline & Methionine & (Met) & $20(2.7 \%)$ & $13(1.8 \%)$ & $15(2.0 \%)$ & $20(2.7 \%)$ & $17(2.3 \%)$ \\
\hline & Phenyl Alanine & (Phe) & $25(3.4 \%)$ & $24(3.3 \%)$ & $25(3.4 \%)$ & $26(3.5 \%)$ & $26(3.5 \%)$ \\
\hline & Proline & (Pro) & $40(5.4 \%)$ & $42(5.7 \%)$ & $40(5.4 \%)$ & $42(5.7 \%)$ & $37(5.0 \%)$ \\
\hline & Serine & (Ser) & $47(6.4 \%)$ & $49(6.6 \%)$ & $44(6.0 \%)$ & $48(6.5 \%)$ & $51(6.6 \%)$ \\
\hline & Threonine & (Thr) & $41(5.5 \%)$ & $39(5.3 \%)$ & $32(4.3 \%)$ & $38(5.1 \%)$ & $49(6.9 \%)$ \\
\hline & Tryptophan & $(\operatorname{Trp})$ & $04(0.5 \%)$ & $04(0.5 \%)$ & $05(0.7 \%)$ & $04(0.5 \%)$ & $05(0.7 \%)$ \\
\hline & Tyrosine & (Tyr) & $22(3.0 \%)$ & $22(3.0 \%)$ & $24(3.2 \%)$ & $21(2.8 \%)$ & $21(2.8 \%)$ \\
\hline & Valine & (Val) & $37(5.0 \%)$ & $45(6.1 \%)$ & $34(4.6 \%)$ & $42(5.7 \%)$ & $36(4.9 \%)$ \\
\hline \multicolumn{3}{|l|}{ Molecular weight } & 82905.24 & 81804.90 & 83452.62 & 83286.68 & 83308.50 \\
\hline \multicolumn{3}{|l|}{ Theoritical pI } & 4.90 & 4.73 & 4.91 & 4.98 & 5.13 \\
\hline \multicolumn{3}{|c|}{ Atomic composition } & 11487 & 11365 & 11557 & 11535 & 11541 \\
\hline \multicolumn{3}{|c|}{ Total number of positively charged residues } & 68 & 63 & 70 & 71 & 70 \\
\hline \multicolumn{3}{|c|}{ Total number of Negatively charged residues } & 113 & 117 & 118 & 118 & 111 \\
\hline \multicolumn{3}{|c|}{ Extinction coefficient assuming cystine residues } & $54905 \mathrm{M}^{-1} \mathrm{~cm}^{-1}$ & $54905 \mathrm{M}^{-1} \mathrm{~cm}^{-1}$ & $63385 \mathrm{M}^{-1} \mathrm{~cm}^{-1}$ & $53415 \mathrm{M}^{-1} \mathrm{~cm}^{-1}$ & $58915 \mathrm{M}^{-1} \mathrm{~cm}^{-1}$ \\
\hline \multicolumn{3}{|c|}{ Absorbance assuming cystine residues } & 0.662 & 0.671 & 0.760 & 0.641 & 0.707 \\
\hline \multicolumn{3}{|c|}{ Extinction coefficient with out cystine residues } & $54780 \mathrm{M}^{-1} \mathrm{~cm}^{-1}$ & $54780 \mathrm{M}^{-1} \mathrm{~cm}^{-1}$ & $63260 \mathrm{M}^{-1} \mathrm{~cm}^{-1}$ & $53290 \mathrm{M}^{-1} \mathrm{~cm}^{-1}$ & $58790 \mathrm{M}^{-1} \mathrm{~cm}^{-1}$ \\
\hline \multicolumn{3}{|c|}{ Absorbance with out cystine residues } & 0.661 & 0.670 & 0.758 & 0.640 & 0.706 \\
\hline \multicolumn{3}{|l|}{ Instability Index } & 45.60 & 38.60 & 46.18 & $\mathbf{5 0 . 3 1}$ & 46.88 \\
\hline \multicolumn{3}{|l|}{ Aliphatic Index } & 75.82 & 80.75 & 77.93 & 74.32 & 73.15 \\
\hline \multicolumn{3}{|l|}{ Grand Average of Hydrophaticity } & -0.642 & -0.565 & -0.688 & -0.691 & -0.714 \\
\hline
\end{tabular}

Table-1:The above table describes different physico-chemical properties associated with the nucleo-protein of Ebola virus species,in which allforms of nucleo-protein in all species of the ebola virus species have same number and composition of the aminoacids on the whole but varieswhen compared with the individual aminoacids. When we calculated average isotope mass of the aminoacid in the protein and one watermolecule the total molecular weight of the protein is estimated to be in this order i.e;83452.62 >83308.50>83286.68 >82905.24 >81804.90.i.e; Reston ebola virus with greater molecular weight and Sudan Ebolavirus with the smaller molecular weight.Compute $\mathrm{pI} / \mathrm{Mw}$ algorithmis mainly used to enhance a region in a 2-D gel to which an a protein which is unmodified should allowed to run, and point a region in which modified form of protein should be found if the modifications are documented in the database. when we calculated the sums of different aminoacid contributions assuming them as independent with out considering the secondary and tertiary structures,we observed similar values of extinction coefficient for Bundibugyo and Sudan ebola virus with and with out assuming cysteine residues with different absorbance.Thenucleo-protein of sudan ebola virus is more stable when compared with the other forms of the virus species with value 38.60 as the value is less than 40 and Zaire Ebola virus is more unstable as it exceeds value greater than 40 .when we determined the positive factor which explains the increment phenomenon of the globular proteins and volume occupied relatively by the aliphatic side chains we observed 80.75(Sudan Ebolavirus) > 77.93(Reston Ebolavirus) $>75.82$ (Bundibugyo Ebolavirus)>74.32 (Zaire Ebolavirus) >73.15 (Tai forest Ebola virus) and when we studied the phenomenon of the protein that is exhibiting the ability of repelling from the water,the hydrophobicity value of the Sudan Ebolavirus(-0.565) is greater and for the TaiforestEbolavirus($0.714)$ is-less 
International Journal of Engineering Applied Sciences and Technology, 2020

Vol. 4, Issue 9, ISSN No. 2455-2143, Pages 241-271

Published Online January 2020 in IJEAST (http://www.ijeast.com)

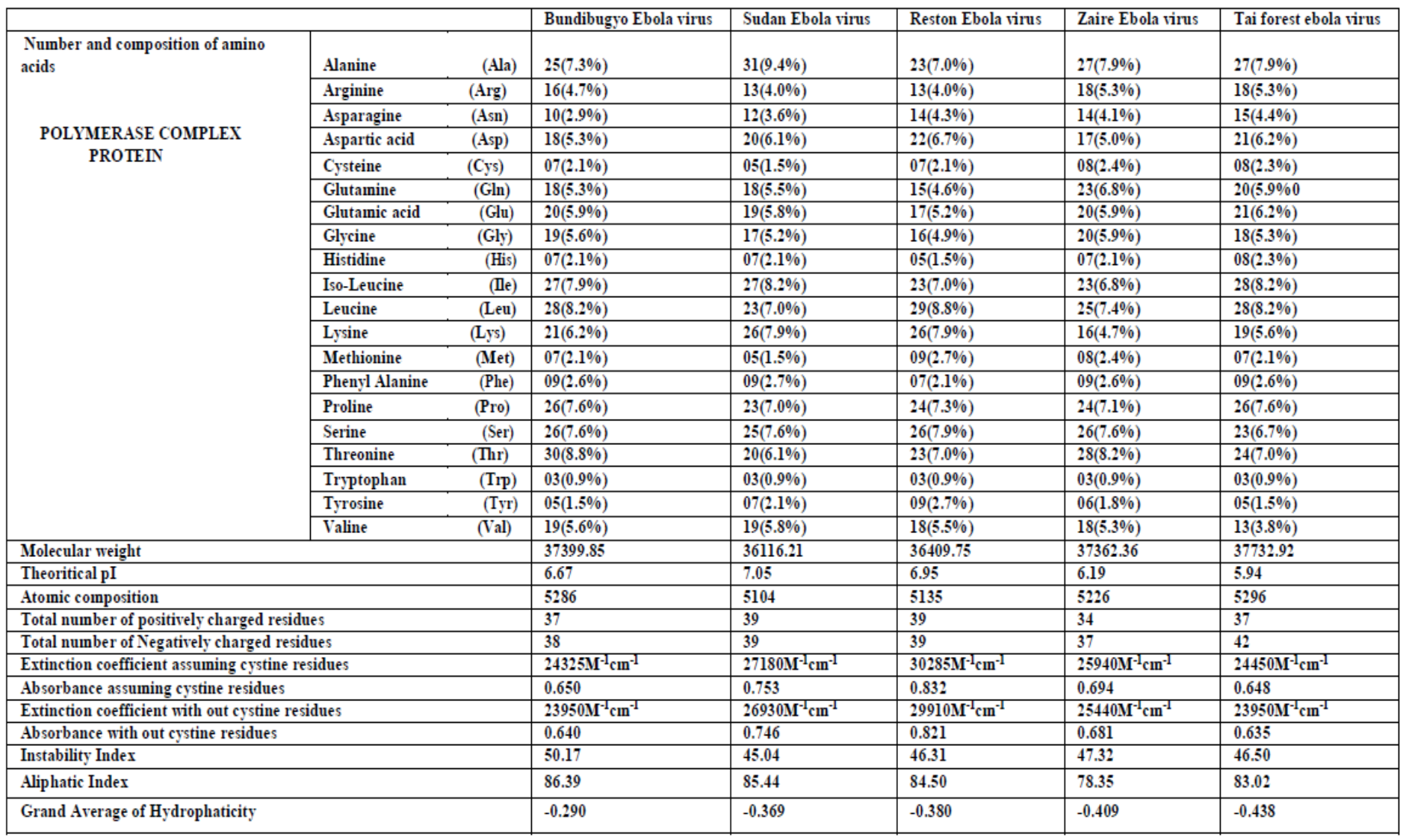

Table-2:The different physico-chemical properties of polymerase complex protein of the ebola virus is described in the above table in which,the total number shows approximation in its value(Similarity in total number of Amino acids showing similarity in two to three amino acid number)but differs in the individual amino acids. Average isotope mass on protein and one water molecule with respect to each aminoacid is calculated then the total molecular weight of the protein is obtained in this order i e; $37732.92>37399.85>37362.36>36409.75>36116.21$. By this we can say that Tai forest Ebola virus having greater molecular weight and Sudan Ebola virus with smaller molecular weight. Compute $\mathrm{pI} / \mathrm{Mw}$ algorithmis mainly used to enhance a region in a 2-D gel to which an a protein which is unmodified should allowed to run,and point a region in which modified form of protein should be found if the modifications are documented in the databaseAssuming the different independent amino acid contributions with out considering the secondary and tertiary structures,we observed different values of Extinction coefficient with different absorbance values in both cases of assuming and non assuming cysteine residues. All the Polymerase complex proteins in all the Ebola virus species is not stable and this can be justified based upon the values we got i.e;all the values obtained is greater than 40 . When the positive factor which explains the increment phenomenon of the globular protein and volume occupied by the aliphatic side chains is determined the values are 78.35 (Zaire Ebolavirus)> 83.02(Tai forest Ebolavirus ) $>84.50$ (Reston Ebolavirus) >85.44(Sudan Ebolavirus) >86.39(Bundibugyo Ebolavirus).The repelling capacity of the protein in Bundibugyo Ebolavirus(-0.290) is higher and the repelling capacity of protein in the Tai forest Ebola virus(-0.438)is less 
International Journal of Engineering Applied Sciences and Technology, 2020

Vol. 4, Issue 9, ISSN No. 2455-2143, Pages 241-271

Published Online January 2020 in IJEAST (http://www.ijeast.com)

\begin{tabular}{|c|c|c|c|c|c|c|}
\hline & & & Tai forest Ebola virus & Sudan Ebola virus & Reston Ebola virus & Zaire Ebola virus \\
\hline $\begin{array}{l}\text { Number and composition of amino } \\
\text { acids }\end{array}$ & Alanine & (Ala) & $19(5.8 \%)$ & $21(6.4 \%)$ & $23(6.9 \%)$ & $22(6.7 \%)$ \\
\hline & Arginine & $(\mathrm{Arg})$ & $12(3.7 \%)$ & $10(3.1 \%)$ & $11(3.3 \%)$ & $11(3.4 \%)$ \\
\hline MATRIX -PROTEIN & Asparagine & (Asn) & $16(4.9 \%)$ & $11(3.4 \%)$ & $13(3.9 \%)$ & $14(4.3 \%)$ \\
\hline & Aspartic acid & (Asp) & $18(5.5 \%)$ & $19(5.8 \%)$ & $20(6.0 \%)$ & $17(5.2 \%)$ \\
\hline & Cysteine & (Cys) & $02(0.6 \%)$ & $02(0.6 \%)$ & $02(0.6 \%)$ & $02(0.6 \%)$ \\
\hline & Glutamine & (Gln) & $12(3.7 \%)$ & $15(4.6 \%)$ & $14(4.2 \%)$ & $11(3.4 \%)$ \\
\hline & Glutamic acid & (Glu) & $08(2.5 \%)$ & $07(2.1 \%)$ & $06(1.8 \%)$ & $09(2.8 \%)$ \\
\hline & Glycine & (Gly) & $19(5.8 \%)$ & $20(6.1 \%)$ & $19(5.7 \%)$ & $21(6.4 \%)$ \\
\hline & Histidine & (His) & $07(2.1 \%)$ & $08(2.5 \%)$ & $09(2.7 \%)$ & $07(2.1 \%)$ \\
\hline & Iso-Leucine & (Ile) & $26(8.0 \%)$ & $24(7.4 \%)$ & $25(7.6 \%)$ & $27(8.3 \%)$ \\
\hline & Leucine & (Leu) & $35(10.7 \%)$ & $35(10.7 \%)$ & $36(10.9 \%)$ & $33(10.1 \%)$ \\
\hline & Lysine & (Lys) & $16(4.9 \%)$ & $20(6.1 \%)$ & $18(5.4 \%)$ & $18(5.5 \%)$ \\
\hline & Methionine & (Met) & $11(3.4 \%)$ & $11(3.4 \%)$ & $08(2.4 \%)$ & $08(2.5 \%)$ \\
\hline & Phenyl Alanine & (Phe) & $09(2.8 \%)$ & $09(2.8 \%)$ & $07(2.1 \%)$ & $10(3.1 \%)$ \\
\hline & Proline & (Pro) & $37(11.3 \%)$ & $36(11.0 \%)$ & $40(12.1 \%)$ & $37(11.3 \%)$ \\
\hline & Serine & (Ser) & $22(6.7 \%)$ & $23(7.1 \%)$ & $22(6.6 \%)$ & $22(6.7 \%)$ \\
\hline & Threonine & (Thr) & $31(9.5 \%)$ & $23(7.1 \%)$ & $23(6.9 \%)$ & $29(8.9 \%)$ \\
\hline & Tryptophan & $(\operatorname{Trp})$ & $02(0.6 \%)$ & $02(0.6 \%)$ & $02(0.6 \%)$ & $02(0.6 \%)$ \\
\hline & Tyrosine & (Tyr) & $07(2.1 \%)$ & $08(2.5 \%)$ & $08(2.4 \%)$ & $06(1.8 \%)$ \\
\hline & Valine & (Val) & $17(5.2 \%)$ & $22(6.7 \%)$ & $25(7.6 \%)$ & $20(6.1 \%)$ \\
\hline Molecular weight & & & 35525.19 & 35475.35 & 35820.66 & 35182.83 \\
\hline Theoritical pI & & & 8.44 & 8.91 & 8.73 & 8.76 \\
\hline Atomic composition & & & 5056 & 5064 & 5123 & 5026 \\
\hline Total number of positively charged $r$ & & & 28 & 30 & 29 & 29 \\
\hline Total number of Negatively charged & & & 26 & 26 & 26 & 26 \\
\hline Extinction coefficient assuming cysti & idues & & $21555 \mathrm{M}^{-1} \mathrm{~cm}^{-1}$ & $23045 \mathrm{M}^{-1} \mathrm{~cm}^{-1}$ & $23045 \mathrm{M}^{-1} \mathrm{~cm}^{-1}$ & $20065 \mathrm{M}^{-1} \mathrm{~cm}^{-1}$ \\
\hline Absorbance assuming cystine residue & & & 0.607 & 0.650 & 0.643 & 0.570 \\
\hline Extinction coefficient with out cystin & lues & & $21430 \mathrm{M}^{-1} \mathrm{~cm}^{-1}$ & $22920 \mathrm{M}^{-1} \mathrm{~cm}^{-1}$ & $22920 \mathrm{M}^{-1} \mathrm{~cm}^{-1}$ & $19940 \mathrm{M}^{-1} \mathrm{~cm}^{-1}$ \\
\hline Absorbance with out cystine residues & & & 0.603 & 0.646 & 0.640 & 0.567 \\
\hline Instability Index & & & 40.13 & 41.76 & 41.41 & 40.39 \\
\hline Aliphatic Index & & & 93.93 & 96.60 & 100.73 & 96.32 \\
\hline Grand Average of Hydrophaticity & & & -0.117 & -0.063 & -0.048 & -0.052 \\
\hline
\end{tabular}

Table-3:The matrix protein of all Ebola virus species shows approximation in the values illustrating total number and composition of the amino acids but completely varies in the individual amino acids. On the protein and Water molecule the average isotope mass with respect to each amino acid is calculated and the values are obtained to be 35820.66>35525.19 $>35475.35>35458.31>35182.83$ i.e; Reston Ebolavirus with the greater molecular weight and Zaire Ebolavirus with smaller molecular weight. Compute $\mathrm{pI} / \mathrm{Mw}$ algorithmis mainly used to enhance a region in a 2-D gel to which an a protein which is unmodified should allowed to run, and point a region in which modified form of protein should be found if the modifications are documented in the databaseWithout considering the secondary and tertiary structures when independent aminoacid contributions are studied we observed different values of the extinction coefficient with the different values of the absorbance in both the cases i.e; assuming and non assuming the cysteine residues.The matrix protein of the all the species of the Ebola virus are not stable as the values are greater than 40 .The increment phenomeneon of the globular protein explaining the positive factor and volume occupied by the aliphatic side chains are studied then the obtained values are in this order100.73 (Reston Ebolavirus) >96.63 (Bundibugyo Ebolavirus) $>96.60$ (Sudan Ebolavirus) > 96.32(Zaire Ebolavirus) $>93.93$ (Taiforest Ebolavirus).The Protein repelling capacity in the Bundibugyo Ebolavirus(-0.037) is greater and the repelling capacity of the Tai forest Ebola virus(-0.117) is less. 
International Journal of Engineering Applied Sciences and Technology, 2020

Vol. 4, Issue 9, ISSN No. 2455-2143, Pages 241-271

Published Online January 2020 in IJEAST (http://www.ijeast.com)

\begin{tabular}{|c|c|c|c|c|c|c|c|}
\hline & & & Bundibugyo Ebola virus & Sudan Ebola virus & Reston Ebola virus & Zaire Ebola virus & Tai forest ebola virus \\
\hline \multirow[t]{3}{*}{$\begin{array}{l}\text { Number and composition of amino } \\
\text { acids }\end{array}$} & Alanine & (Ala) & $14(4.6 \%)$ & $20(6.3 \%)$ & $15(4.5 \%)$ & $16(5.4 \%)$ & $17(5.6 \%)$ \\
\hline & Arginine & (Arg) & $14(4.6 \%)$ & $21(6.6 \%)$ & $20(6.0 \%)$ & $17(5.7 \%)$ & $15(5.0 \%)$ \\
\hline & Asparagine & (Asn) & $18(6.0 \%)$ & $15(4.7 \%)$ & $19(5.7 \%)$ & $13(4.4 \%)$ & $17(5.6 \%)$ \\
\hline \multirow{17}{*}{$\begin{array}{c}\text { SECOND SECRETED GLYCO } \\
\text { PROTEIN }\end{array}$} & Aspartic acid & (Asp) & $12(4.0 \%)$ & $16(5.0 \%)$ & $13(3.9 \%)$ & $13(4.4 \%)$ & $13(4.3 \%)$ \\
\hline & Cysteine & (Cys) & $05(1.7 \%)$ & $05(1.6 \%)$ & $06(1.8 \%)$ & $05(1.7 \%)$ & $06(2.0 \%)$ \\
\hline & Glutamine & (Gln) & $08(2.6 \%)$ & $12(3.8 \%)$ & $11(3.3 \%)$ & $09(3.0 \%)$ & $07(2.3 \%)$ \\
\hline & Glutamic acid & (Glu) & $17(5.6 \%)$ & $17(5.3 \%)$ & $18(5.4 \%)$ & $18(6.1 \%)$ & $16(5.3 \%)$ \\
\hline & Glycine & (Gly) & $21(7.0 \%)$ & $21(6.6 \%)$ & $24(7.3 \%)$ & $24(8.1 \%)$ & $21(7.0 \%)$ \\
\hline & Histidine & (His) & $08(2.6 \%)$ & $07(2.2 \%)$ & $07(2.1 \%)$ & $05(1.7 \%)$ & $08(2.6 \%)$ \\
\hline & Iso-Leucine & (Ile) & $11(3.6 \%)$ & $16(5.0 \%)$ & $11(3.3 \%)$ & $14(4.7 \%)$ & $14(4.6 \%)$ \\
\hline & Leucine & (Leu) & $25(8.3 \%)$ & $29(9.1 \%)$ & $34(10.3 \%)$ & $25(8.4 \%)$ & $25(8.3 \%)$ \\
\hline & Lysine & (Lys) & $18(6.0 \%)$ & $16(5.0 \%)$ & $19(5.7 \%)$ & $16(5.4 \%)$ & $19(6.3 \%)$ \\
\hline & Methionine & (Met) & $03(1.0 \%)$ & $02(0.6 \%)$ & $04(1.2 \%)$ & $01(0.3 \%)$ & $03(1.0 \%)$ \\
\hline & Phenyl Alanine & (Phe) & $21(7.0 \%)$ & $21(6.6 \%)$ & $17(5.1 \%)$ & $20(6.7 \%)$ & $22(7.3 \%)$ \\
\hline & Proline & (Pro) & $20(6.6 \%)$ & $18(5.7 \%)$ & $23(6.9 \%)$ & $17(5.7 \%)$ & $18(6.0 \%)$ \\
\hline & Serine & (Ser) & $16(5.3 \%)$ & $22(6.9 \%)$ & $25(7.6 \%)$ & $20(6.7 \%)$ & $17(5.6 \%)$ \\
\hline & Threonine & (Thr) & $27(8.9 \%)$ & $23(7.2 \%)$ & $27(8.2 \%)$ & $26(8.8 \%)$ & $25(8.3 \%)$ \\
\hline & Tryptophan & $(\operatorname{Trp})$ & $06(2.0 \%)$ & $07(2.2 \%)$ & $08(2.4 \%)$ & $06(2.0 \%)$ & $06(2.0 \%)$ \\
\hline & Tyrosine & (Tyr) & $11(3.6 \%)$ & $11(3.5 \%)$ & $10(3.0 \%)$ & $11(3.7 \%)$ & $09(3.0 \%)$ \\
\hline & Valine & (Val) & $27(8.9 \%)$ & $19(6.0 \%)$ & $20(6.0 \%)$ & $21(7.1 \%)$ & $24(7.9 \%)$ \\
\hline \multicolumn{3}{|l|}{ Molecular weight } & 34184.97 & 36146.05 & 37352.50 & 33391.87 & 34082.99 \\
\hline \multicolumn{3}{|l|}{ Theoritical pI } & 8.49 & 8.71 & 9.14 & 8.19 & 8.81 \\
\hline \multicolumn{3}{|c|}{ Atomic composition } & 4793 & 5065 & 5235 & 4681 & 4786 \\
\hline \multicolumn{3}{|c|}{ Total number of positively charged residues } & 32 & 37 & 39 & 33 & 34 \\
\hline \multicolumn{3}{|c|}{ Total number of Negatively charged residues } & 29 & 33 & 31 & 31 & 29 \\
\hline \multicolumn{3}{|c|}{ Extinction coefficient assuming cystine residues } & $49640 \mathrm{M}^{-1} \mathrm{~cm}^{-1}$ & $55140 \mathrm{M}^{-1} \mathrm{~cm}^{-1}$ & $59275 \mathrm{M}^{-1} \mathrm{~cm}^{-1}$ & $49640 \mathrm{M}^{-1} \mathrm{~cm}^{-1}$ & $46785 \mathrm{M}^{-1} \mathrm{~cm}^{-1}$ \\
\hline \multicolumn{3}{|c|}{ Absorbance assuming cystine residues } & 1.452 & 1.525 & 1.587 & 1.487 & 1.373 \\
\hline \multicolumn{3}{|c|}{ Extinction coefficient with out cystine residues } & $49390 \mathrm{M}^{-1} \mathrm{~cm}^{-1}$ & $54890 \mathrm{M}^{-1} \mathrm{~cm}^{-1}$ & $58900 \mathrm{M}^{-1} \mathrm{~cm}^{-1}$ & $49390 \mathrm{M}^{-1} \mathrm{~cm}^{-1}$ & $46410 \mathrm{M}^{-1} \mathrm{~cm}^{-1}$ \\
\hline \multicolumn{3}{|c|}{ Absorbance with out cystine residues } & 1.445 & 1.519 & 1.577 & 1.479 & 1.362 \\
\hline \multicolumn{3}{|l|}{ Instability Index } & 29.22 & 37.58 & 31.45 & 31.11 & 27.34 \\
\hline \multicolumn{3}{|l|}{ Aliphatic Index } & 77.05 & 78.81 & 75.08 & 77.10 & 79.04 \\
\hline \multicolumn{3}{|l|}{ Grand Average of Hydrophaticity } & -0.275 & -0.339 & -0.440 & -0.289 & -0.220 \\
\hline
\end{tabular}

Table-4:The second Secreted glycol-protein shows approximation in the total number and the composition of the aminoacid and difference when compared individual aminoacids.The average isotope mass on the protein and water molecule are examined and results are obtained in this order i.e;37352.50>36146.05>34184.97>34082.99 > 3339187. By these studies we concluded that Reston Ebolavirus is having higher molecular weight and Zaire Ebolavirus with small molecular weight. Compute $\mathrm{pI} / \mathrm{Mw}$ algorithmis mainly used to enhance a region in a 2-D gel to which an a protein which is unmodified should allowed to run,and point a region in which modified form of protein should be found if the modifications are documented in the databaseWhen independent aminoacid contributions are studied with out considering the secondary and tertiary structure we observed different values of the extinction coefficient with different absorbance both assuming and not assuming the cysteine residues. When we studied the protein stability the secondary secreted protein of all the Ebola species, every organism shows its stability and this can be justified based on the values obtained and all the values obtained are less than 40 . When the positive factor explaining the increment phenomenon of the globular proteins and aliphatic side chains are studied the values are obtained in this order .i.e; 79.04(Tai forest Ebolavirus) > 78.81(Sudan Ebolavirus) > 77.10(Zaire Ebolavirus) $>77.05$ (Bundibugyo Ebolavirus) $>75.08$ (Reston Ebolavirus). The repelling capacity of the protein in the Taiforest Ebolavirus(-0.220) is greater and in the Reston Ebola virus(0.440)isless 
International Journal of Engineering Applied Sciences and Technology, 2020

Vol. 4, Issue 9, ISSN No. 2455-2143, Pages 241-271

Published Online January 2020 in IJEAST (http://www.ijeast.com)

\begin{tabular}{|c|c|c|c|c|c|c|c|}
\hline & & & Bundibugyo Ebola virus & Sudan Ebola virus & Reston Ebola virus & Zaire Ebola virus & Tai forest ebola virus \\
\hline $\begin{array}{l}\text { Number and composition of amino } \\
\text { acids }\end{array}$ & Alanine & (Ala) & $17(4.6 \%)$ & $18(4.8 \%)$ & $16(4.4 \%)$ & $17(4.7 \%)$ & $17(4.7 \%)$ \\
\hline \multirow{19}{*}{$\begin{array}{l}\text { SMALL SECRETED GLYCO } \\
\text { PROTEN }\end{array}$} & Arginine & (Arg) & $23(6.2 \%)$ & $24(6.5 \%)$ & $23(6.3 \%)$ & $21(5.8 \%)$ & $24(6.6 \%)$ \\
\hline & Asparagine & (Asn) & $17(4.6 \%)$ & $17(4.6 \%)$ & $17(4.6 \%)$ & $13(3.6 \%)$ & $17(4.7 \%)$ \\
\hline & Aspartic acid & (Asp) & $12(3.2 \%)$ & $15(4.0 \%)$ & $14(3.8 \%)$ & $13(3.6 \%)$ & $13(3.6 \%)$ \\
\hline & Cysteine & (Cys) & $08(2.1 \%)$ & $08(2.2 \%)$ & $08(2.2 \%)$ & $08(2.2 \%)$ & $09(2.5 \%)$ \\
\hline & Glutamine & (Gln) & $18(4.8 \%)$ & $17(4.6 \%)$ & $16(4.4 \%)$ & $17(4.7 \%)$ & $17(4.7 \%)$ \\
\hline & Glutamic acid & (Glu) & $19(5.1 \%)$ & $23(6.2 \%)$ & $20(5.4 \%)$ & $22(6.0 \%)$ & $17(4.7 \%)$ \\
\hline & Glycine & (Gly) & $22(5.9 \%)$ & $25(6.7 \%)$ & $23(6.3 \%)$ & $26(7.1 \%)$ & $21(5.8 \%)$ \\
\hline & Histidine & (His) & $08(2.1 \%)$ & $10(2.7 \%)$ & $08(2.2 \%)$ & $04(1.1 \%)$ & $07(1.9 \%)$ \\
\hline & Iso-Leucine & (पe) & $13(3.5 \%)$ & $19(5.1 \%)$ & $13(3.5 \%)$ & $16(4.4 \%)$ & $15(4.1 \%)$ \\
\hline & Leucine & (Leu) & $29(7.8 \%)$ & $33(8.9 \%)$ & $34(9.3 \%)$ & $34(9.3 \%)$ & $30(8.2 \%)$ \\
\hline & Lysine & (Lys) & $22(5.9 \%)$ & $22(5.9 \%)$ & $23(6.3 \%)$ & $25(6.9 \%)$ & $23(6.3 \%)$ \\
\hline & Methionine & (Met) & $03(0.8 \%)$ & $04(1.1 \%)$ & $05(1.4 \%)$ & $01(0.3 \%)$ & $03(0.8 \%)$ \\
\hline & Phenyl Alanine & (Phe) & $23(6.2 \%)$ & $21(5.6 \%)$ & $20(5.4 \%)$ & $22(6.0 \%)$ & $24(6.6 \%)$ \\
\hline & Proline & (Pro) & $30(8.0 \%)$ & $23(6.2 \%)$ & $27(7.4 \%)$ & $20(5.5 \%)$ & $25(6.8 \%)$ \\
\hline & Serine & (Ser) & $23(6.2 \%)$ & $26(7.0 \%)$ & $26(7.1 \%)$ & $25(6.9 \%)$ & $24(6.6 \%)$ \\
\hline & Threonine & (Thr) & $37(9.9 \%)$ & $25(6.7 \%)$ & $34(9.3 \%)$ & $34(9.3 \%)$ & $35(9.6 \%)$ \\
\hline & Tryptophan & $(\operatorname{Trp})$ & $08(2.1 \%)$ & $08(2.2 \%)$ & $09(2.5 \%)$ & $08(2.2 \%)$ & $08(2.2 \%)$ \\
\hline & Tyrosine & (Tyr) & $13(3.5 \%)$ & $14(3.8 \%)$ & $10(2.7 \%)$ & $12(3.3 \%)$ & $11(3.0 \%)$ \\
\hline & Valine & (Val) & $28(7.5 \%)$ & $20(5.4 \%)$ & $21(5.7 \%)$ & $26(7.1 \%)$ & $25(6.8 \%)$ \\
\hline \multicolumn{3}{|l|}{ Molecular weight } & 42471.48 & 42584.49 & 41744.64 & 41175.11 & 41655.71 \\
\hline \multicolumn{3}{|l|}{ Theoritical pI } & 9.41 & 8.98 & 9.31 & 9.20 & 9.55 \\
\hline \multicolumn{3}{|c|}{ Atomic composition } & 5959 & 5960 & 5852 & 5809 & 5854 \\
\hline \multicolumn{3}{|c|}{ Total number of positively charged residues } & 45 & 46 & 46 & 46 & 47 \\
\hline \multicolumn{3}{|c|}{ Total number of Negatively charged residues } & 31 & 38 & 34 & 35 & 30 \\
\hline \multicolumn{3}{|c|}{ Extinction coefficient assuming cystine residues } & $63870 \mathrm{M}^{-1} \mathrm{~cm}^{-1}$ & $65360 \mathrm{M}^{-1} \mathrm{~cm}^{-1}$ & $64900 \mathrm{M}^{-1} \mathrm{~cm}^{-1}$ & $62380 \mathrm{M}^{-1} \mathrm{~cm}^{-1}$ & $60890 \mathrm{M}^{-1} \mathrm{~cm}^{-1}$ \\
\hline \multicolumn{3}{|c|}{ Absorbance assuming cystine residues } & 1.504 & 1.535 & 1.555 & 1.515 & 1.462 \\
\hline \multicolumn{3}{|c|}{ Extinction coefficient with out cystine residues } & $63370 \mathrm{M}^{-1} \mathrm{~cm}^{-1}$ & $64860 \mathrm{M}^{-1} \mathrm{~cm}^{-1}$ & $64400 \mathrm{M}^{-1} \mathrm{~cm}^{-1}$ & $61880 \mathrm{M}^{-1} \mathrm{~cm}^{-1}$ & $60390 \mathrm{M}^{-1} \mathrm{~cm}^{-1}$ \\
\hline \multicolumn{3}{|c|}{ Absorbance with out cystine residues } & 1.492 & 1.523 & 1.543 & 1.503 & 1.450 \\
\hline \multicolumn{3}{|l|}{ Instability Index } & 39.79 & 39.34 & 31.30 & 34.79 & 34.57 \\
\hline \multicolumn{3}{|l|}{ Aliphatic Index } & 70.24 & 74.95 & 70.90 & 78.96 & 72.60 \\
\hline \multicolumn{3}{|l|}{ Grand Average of Hydrophaticity } & -0.440 & -0.469 & -0.494 & -0.321 & -0.398 \\
\hline
\end{tabular}

Table-5:The Small Secreted Glyco-Protein although shows approximation in total number and composition of aminoacids, but varies when compared to individual aminoacids.In the protein and one water molecule when we calculated the average isotope mass, the total molecular weight of the protein the order is obtained in this way i.e;42584.49>42471.48>41744.64>41655.71 $>41175.11$. Hence by this we can say that the molecular weight of the sudan Ebolavirus is greater and the molecular weight of the Zaire Ebolavirus is Smaller. Compute $\mathrm{pI} / \mathrm{Mw}$ algorithmis mainly used to enhance a region in a 2-D gel to which an a protein which is unmodified should allowed to run,and point a region in which modified form of protein should be found if the modifications are documented in the database When the contributions of the independent aminoacids are studied with out considering the secondary and tertiary structure we observed different values of the extinction coefficient along with their absorbance values both with assuming and with out assuming cysteine residues. The small secreted glycoprotein in all species of the Ebola virus is stable as it has value less than 40. when we determined the positive factor which explains the increment phenomenon of the globular proteins and volume occupied relatively by the aliphatic side chains we observed the values in this order i.e;78.96 (Zaire Ebolavirus) >74.95(Sudan Ebolavirus) > 72.60(Taiforest Ebolavirus) $>70.90$ (Reston Ebolavirus)> 70.24(Bundibugyo Ebolavirus). and when we studied the phenomenon of the protein that is exhibiting the ability of repelling from the water, the hydrophobicity value of the Zaire Ebolavirus is more(-0.321) and Reston Ebolavirus(-0.494) is less. 
International Journal of Engineering Applied Sciences and Technology, 2020

Vol. 4, Issue 9, ISSN No. 2455-2143, Pages 241-271

Published Online January 2020 in IJEAST (http://www.ijeast.com)

\begin{tabular}{|c|c|c|c|c|c|c|c|}
\hline \multirow{3}{*}{$\begin{array}{l}\text { Number and composition of amino } \\
\text { acids }\end{array}$} & & & Bundibugyo Ebola virus & Sudan Ebola virus & Reston Ebola virus & Zaire Ebola rirus & Tai forest ebola virus \\
\hline & Alanine & (Ala) & $34(5.0 \%)$ & $43(6.4 \%)$ & $41(6.1 \%)$ & $48(7.1 \%)$ & $41(6.1 \%)$ \\
\hline & Arginine & $(\mathrm{Arg})$ & $35(5.2 \%)$ & $33(4.9 \%)$ & $28(4.1 \%)$ & $33(4.9 \%)$ & $28(4.1 \%)$ \\
\hline \multirow{18}{*}{ SPIKE GLYCO-PROTEIN } & Asparagine & (Asn) & $43(6.4 \%)$ & $38(5.6 \%)$ & $43(6.4 \%)$ & $37(5.5 \%)$ & $40(5.9 \%)$ \\
\hline & Aspartic acid & (Asp) & $34(5.0 \%)$ & $29(4.3 \%)$ & $30(4.4 \%)$ & $35(5.2 \%)$ & $30(4.4 \%)$ \\
\hline & Cysteine & (Cys) & $12(1.8 \%)$ & $13(1.9 \%)$ & $13(1.9 \%)$ & $12(1.8 \%)$ & $13(1.9 \%)$ \\
\hline & Glutamine & $(\mathrm{Gln})$ & $26(3.8 \%)$ & $28(4.1 \%)$ & $31(4.6 \%)$ & $27(4.0 \%)$ & $25(3.7 \%)$ \\
\hline & Glutamic acid & (Glu) & $38(5.6 \%)$ & $40(5.9 \%)$ & $35(5.2 \%)$ & $36(5.3 \%)$ & $37(5.5 \%)$ \\
\hline & Glycine & (Glv) & $40(5.9 \%)$ & $51(7.5 \%)$ & $49(7.2 \%)$ & $\mathbf{5 3 ( 7 . 8 \% )}$ & $47(7.0 \%)$ \\
\hline & Histidine & (His) & $20(3.0 \%)$ & $15(2.2 \%)$ & $15(2.2 \%)$ & $18(2.7 \%)$ & $18(2.7 \%)$ \\
\hline & Iso-Leucine & (Ile) & $39(5.8 \%)$ & $48(7.1 \%)$ & $39(5.8 \%)$ & $42(6.2 \%)$ & $40(5.9 \%)$ \\
\hline & Leucine & (Leu) & $52(7.7 \%)$ & $60(8.9 \%)$ & $57(8.4 \%)$ & $51(7.5 \%)$ & $54(8.0 \%)$ \\
\hline & Lysine & (Lys) & $26(3.8 \%)$ & $27(4.0 \%)$ & $28(4.1 \%)$ & $30(4.4 \%)$ & $31(4.6 \%)$ \\
\hline & Methionine & (Met) & $06(0.9 \%)$ & $06(0.9 \%)$ & $10(1.5 \%)$ & $04(0.6 \%)$ & $07(1.0 \%)$ \\
\hline & Phenyl Alanine & (Phe) & $29(4.3 \%)$ & $24(3.6 \%)$ & $22(3.2 \%)$ & $30(4.4 \%)$ & $32(4.7 \%)$ \\
\hline & Proline & (Pro) & $56(8.3 \%)$ & $46(6.8 \%)$ & $51(7.5 \%)$ & $35(5.2 \%)$ & $49(7.2 \%)$ \\
\hline & Serine & (Ser) & $36(5.3 \%)$ & $47(7.0 \%)$ & $55(8.1 \%)$ & $48(7.1 \%)$ & $41(6.1 \%)$ \\
\hline & Threonine & (Thr) & $81(12.0 \%)$ & $70(10.4 \%)$ & $65(9.6 \%)$ & $73(10.8 \%)$ & $77(11.4 \%)$ \\
\hline & Tryptophan & (Trp) & $14(2.1 \%)$ & $14(2.1 \%)$ & $14(2.1 \%)$ & $14(2.1 \%)$ & $14(2.1 \%)$ \\
\hline & Tyrosine & (Tyr) & $15(2.2 \%)$ & $16(2.4 \%)$ & $17(2.5 \%)$ & $15(2.2 \%)$ & $12(1.8 \%)$ \\
\hline & Valine & (Val) & $40(5.9 \%)$ & $28(4.1 \%)$ & $34(5.0 \%)$ & $35(5.2 \%)$ & $40(5.9 \%)$ \\
\hline \multicolumn{3}{|l|}{ Molecular weight } & 75689.18 & 74594.18 & 74416.73 & 74464.46 & 74676.43 \\
\hline \multicolumn{3}{|l|}{ Theoritical pI } & 6.01 & 5.97 & 5.96 & 6.16 & 6.16 \\
\hline \multicolumn{3}{|c|}{ Atomic composition } & 10556 & 10434 & 10365 & 10375 & 10441 \\
\hline \multicolumn{3}{|c|}{ Total number of positively charged residues } & 61 & 60 & 56 & 63 & 59 \\
\hline \multicolumn{3}{|c|}{ Total number of Negatively charged residues } & 72 & 69 & 65 & 71 & 67 \\
\hline \multicolumn{3}{|c|}{ Extinction coefficient assuming cystine residues } & $100100 \mathrm{M}^{-1} \mathrm{~cm}^{-1}$ & $101590 \mathrm{M}^{-1} \mathrm{~cm}^{-1}$ & $103080 \mathrm{M}^{-1} \mathrm{~cm}^{-1}$ & $100100 \mathrm{M}^{-1} \mathrm{~cm}^{-1}$ & $95630 \mathrm{M}^{-1} \mathrm{~cm}^{-1}$ \\
\hline \multicolumn{3}{|c|}{ Absorbance assunning cystine residues } & 1.323 & 1.362 & 1.385 & 1.344 & 1.281 \\
\hline \multicolumn{3}{|c|}{ Extinction coefficient with out cystine residues } & $99350 \mathrm{M}^{-1} \mathrm{~cm}^{-1}$ & $100840 \mathrm{M}^{-1} \mathrm{~cm}^{-1}$ & $102330 \mathrm{M}^{-1} \mathrm{~cm}^{-1}$ & $99350 \mathrm{M}^{-1} \mathrm{~cm}^{-1}$ & $94880 \mathrm{M}^{-1} \mathrm{~cm}^{-1}$ \\
\hline \multicolumn{3}{|c|}{ Absorbance with out cystine residues } & 1.313 & 1.352 & 1.375 & 1.334 & 1.271 \\
\hline \multicolumn{3}{|l|}{ Instability Index } & 38.53 & 43.39 & 42.36 & 38.36 & 37.21 \\
\hline \multicolumn{3}{|l|}{ Aliphatic Index } & 74.69 & 80.68 & 75.92 & 75.77 & 77.46 \\
\hline \multicolumn{3}{|l|}{ Grand Average of Hydrophaticity } & -0.466 & -0.352 & -0.404 & -0.380 & $\begin{array}{l}-0.320 \\
\end{array}$ \\
\hline
\end{tabular}

Table-6: The above table describes different physico-chemical properties associated with the Spike glycoProtein of Ebola virus species,in which all forms of spike glycol-protein in all species of the ebola virus species have same number and composition of the aminoacids(approximate values) on the whole but varies when compared with the individual aminoacids. When we calculated average isotope mass of the aminoacid in the protein and one watermolecule the total molecular weight of the protein is estimated to be in this order i.e;75689.18>7467.43>74594.18>74464.46>74416.73, by this we concluded that the Bundibugyo Ebolavirus having greater molecular weight and Reston Ebolavirus with smaller molecular weight.Compute $\mathrm{pI} / \mathrm{Mw}$ algorithmis mainly used to enhance a region in a 2-D gel to which an a protein which is unmodified should allowed to run,and point a region in which modified form of protein should be found if the modifications are documented in the database. when we calculated the sums of different aminoacid contributions assuming them as independent with out considering the secondary and tertiary structures,we observed different values of extinction coefficient with and with out assuming cysteine residues with different absorbance. The spike glycol-protein of the sudan ebol virus and reston Ebolavirus is more unstable when compared with the other forms of the virus species as values are greater than 40 .when we determined the positive factor which explains the increment phenomenon of the globular proteins and volume occupied relatively by the aliphatic side chains we observed 80.68(Sudan Ebolavirus) $>77.46$ (Tai Forest Ebolavirus) > 75.92(Reston Ebolavirus) $>75.77$ (Zaire Ebolavirus) > 74.69 (Bundibugyo Ebolavirus)and when we studied the phenomenon of the protein that is exhibiting the ability of repelling from the water,the hydrophobicity value of the Taiforest Ebolavirus(-0.320) is more and for Bundibugyo Ebolavirus(-0.466), it is less. 
International Journal of Engineering Applied Sciences and Technology, 2020

Vol. 4, Issue 9, ISSN No. 2455-2143, Pages 241-271

Published Online January 2020 in IJEAST (http://www.ijeast.com)

\begin{tabular}{|c|c|c|c|c|c|c|c|}
\hline & Bundibugyo Ebola virus & Sudan Ebola virus & Reston Ebola virus & Zaire Ebola virus & Tai forest ebola rirus \\
\hline \multirow[t]{2}{*}{$\begin{array}{l}\text { Number and composition of amino } \\
\text { acids }\end{array}$} & Alanine & (Ala) & $19(7.6 \%)$ & $15(6.0 \%)$ & $15(6.0 \%)$ & $16(6.4 \%)$ & $20(8.0 \%)$ \\
\hline & Arginine & (Arg) & $10(4.0 \%)$ & $11(4.4 \%)$ & $11(4.4 \%)$ & $10(4.0 \%)$ & $08(3.2 \%)$ \\
\hline \multirow{18}{*}{$\begin{array}{l}\text { MEMBRANE ASSOCLATED } \\
\text { PROTEN }\end{array}$} & Asparagine & (Asn) & $13(5.2 \%)$ & $16(6.4 \%)$ & $14(5.6 \%)$ & $17(6.8 \%)$ & $13(5.2 \%)$ \\
\hline & Aspartic acid & (Asp) & $10(4.0 \%)$ & $09(3.6 \%)$ & $10(4.0 \%)$ & $09(3.6 \%)$ & $09(3.6 \%)$ \\
\hline & Cysteine & (Cys) & $01(0.4 \%)$ & $01(0.4 \%)$ & $01(0.4 \%)$ & $01(0.4 \%)$ & $01(0.4 \%)$ \\
\hline & Glutamine & $(\mathrm{Gln})$ & $14(5.6 \%)$ & $10(4.0 \%)$ & $12(4.8 \%)$ & $12(4.8 \%)$ & $15(6.0 \%)$ \\
\hline & Glutanic acid & (Glu) & $10(4.0 \%)$ & $11(4.4 \%)$ & $08(3.2 \%)$ & $10(4.0 \%)$ & $10(4.0 \%)$ \\
\hline & Glycine & (Gly) & $11(4.4 \%)$ & $11(4.4 \%)$ & $13(5.2 \%)$ & $13(5.2 \%)$ & $13(5.2 \%)$ \\
\hline & Histidine & (His) & $07(2.8 \%)$ & $06(2.4 \%)$ & $06(2.4 \%)$ & $07(2.8 \%)$ & $06(2.4 \%)$ \\
\hline & Iso-Leucine & (Ie) & $17(6.8 \%)$ & $18(7.2 \%)$ & $17(6.8 \%)$ & $19(7.6 \%)$ & $17(6.8 \%)$ \\
\hline & Leucine & (Leu) & $38(15.1 \%)$ & $33(13.1 \%)$ & $36(14.3 \%)$ & $37(14.7 \%)$ & $39(15.5 \%)$ \\
\hline & Lysine & (Lys) & $16(6.4 \%)$ & $13(5.2 \%)$ & $13(5.2 \%)$ & $15(6.0 \%)$ & $17(6.8 \%)$ \\
\hline & Methionine & (Met) & $08(3.2 \%)$ & $09(3.6 \%)$ & $09(3.6 \%)$ & $09(3.6 \%)$ & $08(3.2 \%)$ \\
\hline & Phenyl Alanine & (Phe) & $11(4.4 \%)$ & $10(4.0 \%)$ & $13(5.2 \%)$ & $11(4.4 \%)$ & $09(3.6 \%)$ \\
\hline & Proline & (Pro) & $09(3.6 \%)$ & $13(5.2 \%)$ & $12(4.8 \%)$ & $09(3.6 \%)$ & $10(4.0 \%)$ \\
\hline & Serine & (Ser) & $20(8.0 \%)$ & $19(7.6 \%)$ & $21(8.4 \%)$ & $21(8.4 \%)$ & $18(7.2 \%)$ \\
\hline & Threonine & (Thr) & $17(6.8 \%)$ & $18(7.2 \%)$ & $18(7.2 \%)$ & $17(6.8 \%)$ & $20(8.0 \%)$ \\
\hline & Tryptophan & $(\operatorname{Trp})$ & $05(2.0 \%)$ & $05(2.0 \%)$ & $05(2.0 \%)$ & $05(2.0 \%)$ & $05(2.0 \%)$ \\
\hline & Tyrosine & (Tyr) & $02(0.8 \%)$ & $05(2.0 \%)$ & $03(1.2 \%)$ & $03(1.2 \%)$ & $02(0.8 \%)$ \\
\hline & Valine & (Val) & $13(5.2 \%)$ & $18(7.2 \%)$ & $14(5.6 \%)$ & $10(4.0 \%)$ & $11(4.4 \%)$ \\
\hline \multicolumn{3}{|l|}{ Molecular weight } & 28163.88 & 28276.97 & 28168.88 & 28218.85 & 27887.58 \\
\hline \multicolumn{3}{|l|}{ Theoritical pI } & 9.49 & 9.18 & 9.55 & 9.49 & 9.46 \\
\hline \multicolumn{3}{|l|}{ Atomic composition } & 4031 & 4034 & 4019 & 4023 & 3998 \\
\hline \multicolumn{3}{|c|}{ Total number of positively charged residues } & 26 & 24 & 24 & 25 & 25 \\
\hline \multicolumn{3}{|c|}{ Total number of Negatively charged residues } & 20 & 20 & 18 & 19 & 19 \\
\hline \multicolumn{3}{|c|}{ Extinction coefficient assuming cystine residues } & $30480 \mathrm{M}^{-1} \mathrm{~cm}^{-1}$ & $34950 \mathrm{M}^{-1} \mathrm{~cm}^{-1}$ & $31970 \mathrm{M}^{-1} \mathrm{~cm}^{-1}$ & $31970 \mathrm{M}^{-1} \mathrm{~cm}^{-1}$ & $30480 \mathrm{M}^{-1} \mathrm{~cm}^{-1}$ \\
\hline \multicolumn{3}{|c|}{ Absorbance assuming cystine residues } & 1.082 & 1.236 & 1.135 & 1.133 & 1.093 \\
\hline \multicolumn{3}{|c|}{ Extinction coefficient with out cystine residues } & $30480 \mathrm{M}^{-1} \mathrm{~cm}^{-1}$ & $34950 \mathrm{M}^{-1} \mathrm{~cm}^{-1}$ & $31970 \mathrm{M}^{-1} \mathrm{~cm}^{-1}$ & $31970 \mathrm{M}^{-1} \mathrm{~cm}^{-1}$ & $30480 \mathrm{M}^{-1} \mathrm{~cm}^{-1}$ \\
\hline \multicolumn{3}{|c|}{ Absorbance with out cystine residues } & 1.082 & 1.236 & 1.135 & 1.133 & 1.093 \\
\hline \multicolumn{3}{|l|}{ Instability Index } & 35.69 & 24.36 & 39.95 & 36.51 & 34.47 \\
\hline \multicolumn{3}{|l|}{ Aliphatic Index } & 108.05 & 106.02 & 104.50 & 104.94 & 107.69 \\
\hline \multicolumn{3}{|l|}{ Grand Average of Hydrophaticity } & 0.040 & 0.049 & 0.078 & -0.013 & 0.028 \\
\hline
\end{tabular}

Table-1:The above table describes different physico-chemical properties associated with the membrane associated protein of Ebola virus species, in which allforms of membrane associated protein in all species of the ebola virus species have same number and composition of the aminoacids(approximate values) on the whole but varies when compared with the individual aminoacids. When we calculated average isotope mass of the aminoacid in the protein and one watermolecule the total molecular weight of the protein is estimated to be in this order i.e;28276.97>28218.85>28168.88>28163.88>27887.58 . By this we can say that Sudan Ebolavirus has greater molecular weight and Taiforest Ebolavvirus has smaller molecular weight.Compute $\mathrm{pI} / \mathrm{Mw}$ algorithmis mainly used to enhance a region in a 2-D gel to which an a protein which is unmodified should allowed to run,and point a region in which modified form of protein should be found if the modifications are documented in the database.when we calculated the sums of different aminoacid contributions assuming them as independent with out considering the secondary and tertiary structures, we observed similar values of extinction coefficient and absorbance in all species of Ebola virus with and with out assuming cysteine residues. The membrane associated protein of all virus species is more stable.when we determined the positive factor which explains the increment phenomenon of the globular proteins and volume occupied relatively by the aliphatic side chains we observed the values in this order i.e;108.05(Bundibugyo Ebolavirus) >107.69(Taiforest Ebolavirus) > 106.02(Sudan Ebolavirus)> 104.94 (Zaire Ebolavirus) > 10.50(Reston Ebolavirus)and when we studied the phenomenon of the protein that is exhibiting the ability of repelling from the water,the hydrophobicity value of the Zaire Ebolavirus(-0.013) is smaller and Reston Ebolavirus(0.078) is more 
International Journal of Engineering Applied Sciences and Technology, 2020

Vol. 4, Issue 9, ISSN No. 2455-2143, Pages 241-271

Published Online January 2020 in IJEAST (http://www.ijeast.com)

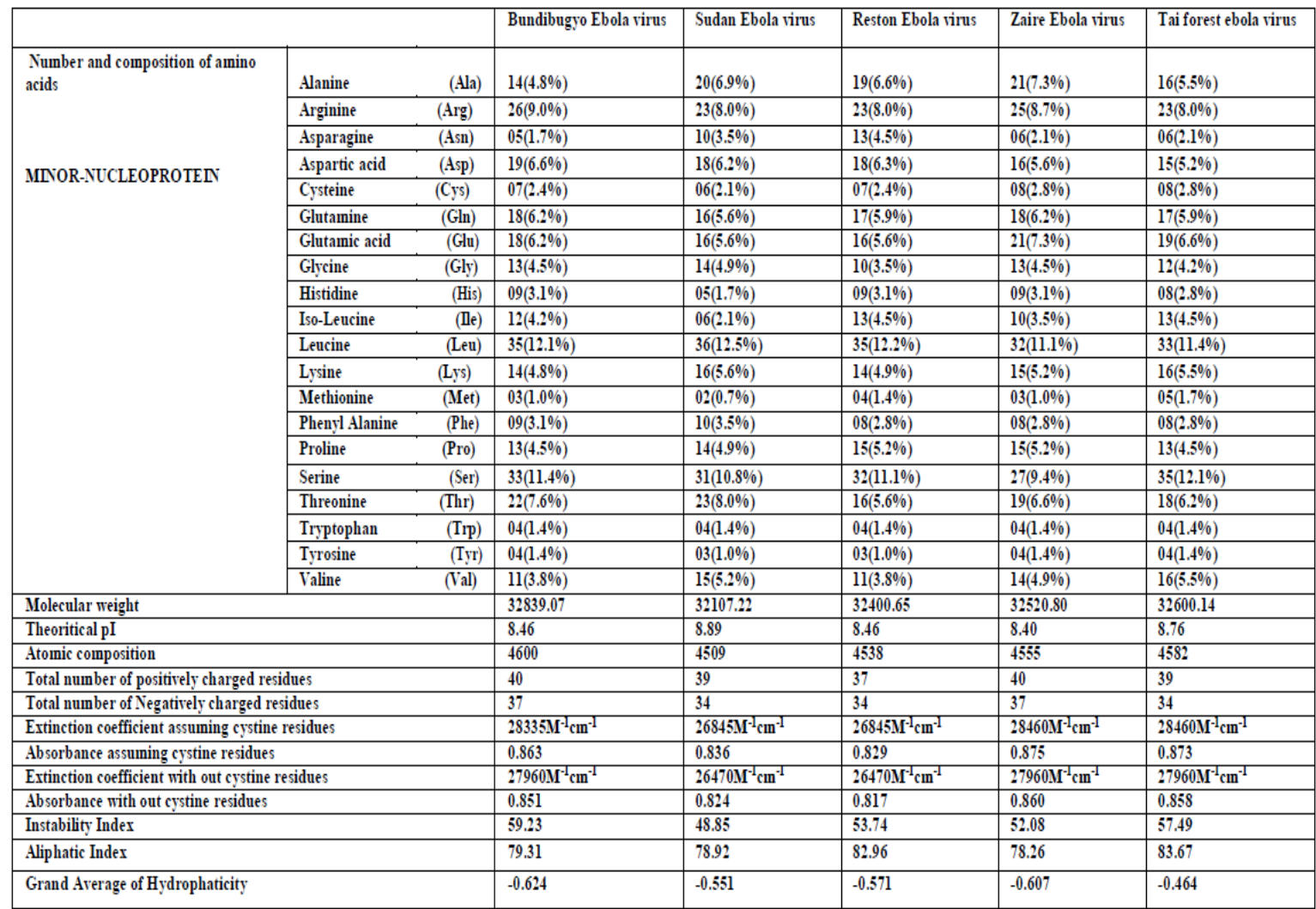

Table-1:The above table describes different physico-chemical properties associated with the minor nucleo- protein of Ebola virus species,in which allforms of minor nucleo protein in all species of the ebola virus species have same number and composition of the aminoacids(approximate values) on the whole but varies when compared with the individual aminoacids. When we calculated average isotope mass of the aminoacid in the protein and one water molecule the total molecular weight of the protein is estimated to be in this order i.e;32839.07>32600.14 >32520.80>21400.65 >32107.22. By this we can say that Bundibugyo Ebolavirus has greater molecular weight and Sudan Ebolavirus has smaller molecular weight.Compute $\mathrm{pI} / \mathrm{Mw}$ algorithmis mainly used to enhance a region in a 2-D gel to which an a protein which is unmodified should allowed to run,and point a region in which modified form of protein should be found if the modifications are documented in the database.when we calculated the sums of different aminoacid contributions assuming them as independent with out considering the secondary and tertiary structures, we observed different values of extinction coefficient and absorbance in all species of Ebola virus with and with out assuming cysteine residues. The Minor Nucleo-protein of all virus species is more unstable.when we determined the positive factor which explains the increment phenomenon of the globular proteins and volume occupied relatively by the aliphatic side chains we observed the values in this order i.e;83.67(Taiforest Ebolavirus) $>82.96$ (Reston Ebolavirus) $>79.31$ (Bundibugyo Ebolavirus) $>78.92$ (Sudan Ebolavirus) $>78.26$ (Zaire Ebolavirus)and when we studied the phenomenon of the protein that is exhibiting the ability of repelling from the water,the hydrophobicity value of the Taiforest Ebolavirus(-0.464) is greater and the value of the Bundibugyo Ebolavirus(-0.624) is less 
International Journal of Engineering Applied Sciences and Technology, 2020

Vol. 4, Issue 9, ISSN No. 2455-2143, Pages 241-271

Published Online January 2020 in IJEAST (http://www.ijeast.com)

\begin{tabular}{|c|c|c|c|c|c|c|c|}
\hline & Bundibugyo Ebola rirus & Sudan Ebola rirus & Reston Ebola rirus & Zaire Ebola virus & Tai forest ebola rirus \\
\hline \multirow[t]{3}{*}{$\begin{array}{l}\text { Number and composition of amino } \\
\text { acids }\end{array}$} & Alanine & (Ala) & $121(5.5 \%)$ & $122(5.5 \%)$ & $115(5.2 \%)$ & $119(5.4 \%)$ & $127(5.7 \%)$ \\
\hline & Arginine & $(\operatorname{Arg})$ & $113(5.1 \%)$ & $131(5.9 \%)$ & $113(5.1 \%)$ & $118(5.3 \%)$ & $119(5.4 \%)$ \\
\hline & Asparagine & (Asn) & $109(4.9 \%)$ & $114(5.2 \%)$ & $126(5.7 \%)$ & $106(4.8 \%)$ & $113(5.1 \%)$ \\
\hline \multirow{17}{*}{$\begin{array}{l}\text { RNA DEPENDENT RNA } \\
\text { POLYMERASE }\end{array}$} & Aspartic acid & (Asp) & $104(4.7 \%)$ & $98(4.4 \%)$ & $107(4.8 \%)$ & $103(4.7 \%)$ & $98(4.4 \%)$ \\
\hline & Cysteine & (Cys) & $44(2.0 \%)$ & $45(2.0 \%)$ & $43(1.9 \%)$ & $43(1.9 \%)$ & $46(2.1 \%)$ \\
\hline & Glutamine & (Gln) & $102(4.6 \%)$ & $91(4.1 \%)$ & $103(4.7 \%)$ & $107(4.8 \%)$ & $97(4.4 \%)$ \\
\hline & Glutamic acid & (Glu) & $107(4.8 \%)$ & $106(4.8 \%)$ & $105(4.7 \%)$ & $109(4.9 \%)$ & $106(4.8 \%)$ \\
\hline & Glycine & (Gly) & $102(4.6 \%)$ & $107(4.8 \%)$ & $108(4.9 \%)$ & $101(4.6 \%)$ & $103(4.7 \%)$ \\
\hline & Histidine & (His) & $70(3.2 \%)$ & $72(3.3 \%)$ & $75(3.4 \%)$ & $76(3.4 \%)$ & $79(3.6 \%)$ \\
\hline & Iso-Leucine & (Ie) & $148(6.7 \%)$ & $153(6.9 \%)$ & $144(6.5 \%)$ & $147(6.6 \%)$ & $151(6.8 \%)$ \\
\hline & Leucine & (Leu) & $255(11.5 \%)$ & $258(11.7 \%)$ & $269(12.2 \%)$ & $250(11.3 \%)$ & $264(11.9 \%)$ \\
\hline & Lysine & (Lys) & $121(5.5 \%)$ & $101(4.6 \%)$ & $116(5.2 \%)$ & $113(5.1 \%)$ & $107(4.8 \%)$ \\
\hline & Methionine & (Met) & $28(1.3 \%)$ & $38(1.7 \%)$ & $34(1.5 \%)$ & $38(1.7 \%)$ & $25(1.1 \%)$ \\
\hline & Phenyl Alanine & (Phe) & $106(4.8 \%)$ & $97(4.4 \%)$ & $102(4.6 \%)$ & $116(5.2 \%)$ & $100(4.5 \%)$ \\
\hline & Proline & (Pro) & $105(4.8 \%)$ & $110(5.0 \%)$ & $98(4.4 \%)$ & $102(4.6 \%)$ & $107(4.8 \%)$ \\
\hline & Serine & (Ser) & $191(8.6 \%)$ & $186(8.4 \%)$ & $184(8.3 \%)$ & $184(8.3 \%)$ & $188(8.5 \%)$ \\
\hline & Threonine & (Thr) & $143(6.5 \%)$ & $153(6.9 \%)$ & $132(6.0 \%)$ & $154(7.0 \%)$ & $151(6.8 \%)$ \\
\hline & Tryptophan & $(\operatorname{Trp})$ & $30(1.4 \%)$ & $29(1.3 \%)$ & $30(1.4 \%)$ & $29(1.3 \%)$ & $29(1.3 \%)$ \\
\hline & Tyrosine & (Tyr) & $93(4.2 \%)$ & $89(4.0 \%)$ & $97(4.4 \%)$ & $87(3.9 \%)$ & $85(3.8 \%)$ \\
\hline & Valine & (Val) & $118(5.3 \%)$ & $110(5.0 \%)$ & $111(5.0 \%)$ & $110(5.0 \%)$ & $115(5.2 \%)$ \\
\hline \multicolumn{3}{|l|}{ Molecular weight } & 251649.28 & 251294.24 & 252549.04 & 252724.47 & 250746.25 \\
\hline \multicolumn{3}{|l|}{ Theoritical pI } & 8.64 & 8.77 & 8.48 & 8.55 & 8.62 \\
\hline \multicolumn{3}{|c|}{ Atomic composition } & 35452 & 35386 & 35520 & 35538 & 35339 \\
\hline \multicolumn{3}{|c|}{ Total number of positively charged residues } & 234 & 232 & 229 & 231 & 226 \\
\hline \multicolumn{3}{|c|}{ Total number of Negatively charged residues } & 211 & 204 & 212 & 212 & 204 \\
\hline \multicolumn{3}{|c|}{ Extinction coefficient assuming cystine residues } & $306320 \mathrm{M}^{-1} \mathrm{~cm}^{-1}$ & $294860 \mathrm{M}^{-1} \mathrm{~cm}^{-1}$ & $312155 \mathrm{M}^{-1} \mathrm{~cm}^{-1}$ & $291755 \mathrm{M}^{-1} \mathrm{~cm}^{-1}$ & $289025 \mathrm{M}^{-1} \mathrm{~cm}^{-1}$ \\
\hline \multicolumn{3}{|c|}{ Absorbance assuming cystine residues } & 1.217 & 1.173 & 1.236 & 1.154 & 1.153 \\
\hline \multicolumn{3}{|c|}{ Extinction coefficient with out cystine residues } & $303570 \mathrm{M}^{-1} \mathrm{~cm}^{-1}$ & $292110 \mathrm{M}^{-1} \mathrm{~cm}^{-1}$ & $309530 \mathrm{M}^{-1} \mathrm{~cm}^{-1}$ & $289130 \mathrm{M}^{-1} \mathrm{~cm}^{-1}$ & $286150 \mathrm{M}^{-1} \mathrm{~cm}^{-1}$ \\
\hline \multicolumn{3}{|c|}{ Absorbance with out cystine residues } & 1.206 & 1.162 & 1.226 & 1.144 & 1.141 \\
\hline \multicolumn{3}{|l|}{ Instability Index } & 39.74 & 42.07 & 41.60 & 41.34 & 40.33 \\
\hline \multicolumn{3}{|l|}{ Aliphatic Index } & 92.08 & 92.48 & 92.57 & 89.80 & 94.07 \\
\hline \multicolumn{3}{|l|}{ Grand Average of Hydrophaticity } & -0.218 & -0.206 & -0.242 & -0.230 & -0.191 \\
\hline
\end{tabular}

Table-1:The above table describes different physico-chemical properties associated with the RNA dependent RNA Polymerase protein of Ebola virus species,in which allforms of RNA dependent RNA Polymerase in all species of the ebola virus species have same number and composition of the aminoacids(approximate values) on the whole but varies when compared with the individual aminoacids. When we calculated average isotope mass of the aminoacid in the protein and one water molecule the total molecular weight of the protein is estimated to be in this order i.e;252724.47>252549.04>251649.28 >251294.24 $>250746.25$ i.e; Zaire Ebolavirus with greater molecular weight and Taiforest Ebola virus with small molecular weight..Compute $\mathrm{pI} / \mathrm{Mw}$ algorithmis mainly used to enhance a region in a 2-D gel to which an a protein which is unmodified should allowed to run,and point a region in which modified form of protein should be found if the modifications are documented in the database.when we calculated the sums of different aminoacid contributions assuming them as independent with out considering the secondary and tertiary structures, we observed different values of extinction coefficient and absorbance in all species of Ebola virus with and with out assuming cysteine residues. The RNA dependent RNA polymerase of Bundibugyo Ebolavirus is more stablewhen compared to other virus species. when we determined the positive factor which explains the increment phenomenon of the globular proteins and volume occupied relatively by the aliphatic side chains we observed the values in this order i.e;94.07(Taiforest Ebolavirus) $>92.57$ (Reston Ebolavirus) $>92.48$ (Sudan Ebolavirus) $>92.08$ (Bundibugyo Ebolavirus) $>89.80$ (Zaire Ebolavirus) and when we studied the phenomenon of the protein that is exhibiting the ability of repelling from the water,the hydrophobicity value of the Taiforest Ebolavirus(-0.191) is greater and the value of the Reston Ebolavirus(-0.242) is less 
International Journal of Engineering Applied Sciences and Technology, 2020

Vol. 4, Issue 9, ISSN No. 2455-2143, Pages 241-271

Published Online January 2020 in IJEAST (http://www.ijeast.com)

MODULE-2

\section{MULTIPLE SEQUENCE ALIGNMENT}

\section{MATRIX PROTEIN}

sudan

Reston

Taiforest

Bundibugy

sudan

Sudan

Taiforest

Bundibugyo

zaire

sudan

Reston

Taiforest

Bundidugyo

sudan

Reston

Taiforest

Bundibugyo

zaire

Sudan

Reston

Taiforest

Bundibugyo

zaire

Sudan
Reston

Taiforest

Bundibugyo

zaire

Sudan

Reston

zaire

Taiforest

Bundibugyo

Sudan

Reston

Zaire

Taiforest

Bundibugyo

Sudan

Reston

zaire

Taiforest

Bundibugyo

Sudan

Reston

Zaire

Taiforest

Bundibugyo

Sudan

Reston

zaire

Taiforest

Bundibugyo
MRRVTVPTAPPAYADIGYPMSMIPIKSSRAVSGIQQKQEVLPGMDTPSNSMRPVADDNID 60 MRRGVLPTAPPAYNDIAY AMSIIPTRPSVIVNETKSDVLAVPGADVPSNSMRPVADDNID 60 MRRAILPTAPPEYIEAVYPMRTVSTSINSTASGPNFPAPDVMMSDTPSNSLRPIADDNID 60

HTSHTPNGVASAFILEATVNVISGPKVLMKQIPIWLPLGIADQKTYSFDSTTAAIMLASY 120 HSSHTPSGVASAFILEATVNVISGTKVLMKQIPIWLPLGVADQKIYSFDSTTAAIMLASY 120 HPSHTPNSVASAFILEAMVNVISGPKVLMKQIPIWLPLGVSDQRTYSFDSTTAAIMLASY 120
HPSHTPTSVSSAFILEAMVNVISGPKVLMKQIPIWLPLGVADQKTYSFDSTTAAIMLASY 120 SAFILEAMVNVI SGPKVLMKQIPIWLPLGVADQKTYSFDSTTAAIMLASY 50

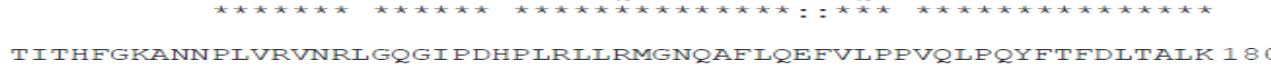
TITHFGKANN PLVRVNRLGQGIPDHPLRLIRMGNQAFLQEFVLPPVQLPQYFTFDLTALK 180 TVTHFGKI SNPLVRVNRLGPGIPDHPLRLIRLGNQAF LQEFVLPPVQLPQYFTFDITAIK 180 TITHFGKT SNPIVRINRIGPGIPDHPLRILRIGNQAFIQEFVIPPVQLPQYFTFDITA TITHFGKATNPLVRVNRIGPGIPDHPLRILRIGNQAFIQEFVLPPVQIPQYFTFDITALK 110

LVTQPLPAATWTDETPSNLSGALRPGLSFHPKLRPVLLPGKTGKKGHVSDLTAPDKIQTI 240 LITQPLPAATWTDETPAGAVNALRPGLSLHPKLRPILLPGKTGKKGHASDITSPDKIQTI 240 LITQPLPAATWTDETPAVSTGTIRPGISFHPKIRPILIPGRAGKKGSNSDITSPDKIQAI 240 LITQPLPAATWTDDTPTGPTGIIRPGISFHPKIRPILIPGKTGKRGSSSDITSPDKIQAI 240
IITQPIPAATWTDDTPTGSNGAIRPGISFHPKLRPIILPNKSGKKGNSADITSPEKIQAI 170

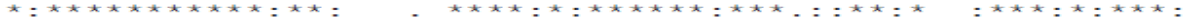

VNLMQDEKIVPIDPAKSIIGIEVPELIVHKLTGKKMSQKNGQPIIPVLIPKYIGLDPISP 300

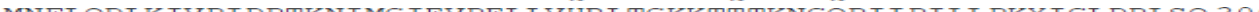
MNNI MTSIQDFKIVPIDPTKNIMGIEVPETLVHKLTGKKVTSKNGQPIIPVIIPKYIGLDPVAP 230 GDITMVITPDYDDCHSPASCSYLSEK----GDLTMVITQDCDSCHSPASHPYHMDKQNSYQ GDTMITQDCDTCHSPASLPPVSEK-- 326 GDLTMVITQDCDTCHSPASIPAVIEK---- $\quad 326$

\section{MEMBRANE ASSOCIATED PROTEIN}

MAKATGRYNLVTPKRELEQGVVFSDLCNFLVTPTVQGWKVYWAGLEFDVNQKGITLLNRL 60 MAKATGRYNLVP PKKDMEKGVIFSDICNFL ITOTLOGWKVYWAGI EFDVSOKGMALITRL 60 MAKATGRYNL IS PKKDLEKGVVLSDLCNFLVSQT I GWKVYWAGIEFDVT HKGMALLHRL 60 MAKATGRYNL ISPKKDLEKGLVLNDLCTLSVAQTVQGWKVTWAGIEFDVTQKGMALLHRL 60 MAKATGRYNLVSPKKDLERGLVLSDLCTFLVDQTIQGWRVTWVGIEFDIAQKGMALLHRL 60

KVNDFAPAWAMTRNLFPHLFKNQQSEVQTP IWALRVI LAAGILDQLMDHSL IEPLSGALN 120 KTNDFA PAWAMTRNLF PHLFQNPNSVIQSP IWALRVI LAAGLQDQLLDHSLVEPLTGALG 120 KTNDFAPAWSMTRNLF PHLFQNPNST IESPLWALRVI LAAGIQDQLI DQSLIEPLAGALG 120 KTSDFA PAWSMTRNLF PHLFQNPNST IESPLWALRVILAAGIQDQL I DQSLIEPLAGALG 120 KTADFAPAWSMTRNLF PHLFONSNST IESPLWALRVI LAAGIQDOLI DQSLVEPLAGALS 120

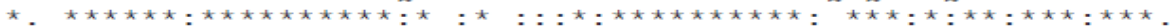

LIADWLLTTSTNHFNMRTQRVKDQLSMRMLSLIRSNI INFINKLETLHVVNYKGLLSSVE 180 LISDWLLTTTSTHFNLRTRSVKDQLS LRMLSLIRSNI LQF INKLDALHVVNYNGLLSSIE 180 L ISDWLLTTNTNHFNMRTQRVKEQLS LKMLSL I RSN I LKF INKLDAL HVVNYNGLLSS IE 180 I IADWLLTTGTNHFOMRTOOAKEOLSLKMLSLVRSNILKFINOLDAL HVVNYNGLISSIE 180 LVSDWLLTTNTNHFQMRTQHAKEQLSLKMLSLVRSNI LKF ISQLDAL HVVNYNGLLSSIE 180

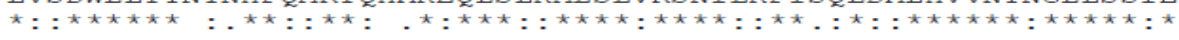

IGTPSYAI I TRTNMGYLVEVQEPDKSAMDIRHPGPVKFSLLHESTLKPVATPKPSSITS 240 IGTSTHTI IITRTNMGFLVEVOEPDKSAMNSKRPGPVKFSLLHESAFKPFTRVPOSGMOS 240 IGTONHTI I I TRTNMGFLVELOEPDKSAMNRMKPGPAKFSLLHESTLKAFTOGSSTRMOS 240 IGTKSHTI I TRTNMGFLVELQEPDKSAMNTRKPGPVKFSLLHESTLKTLAKKPATQMQA 240

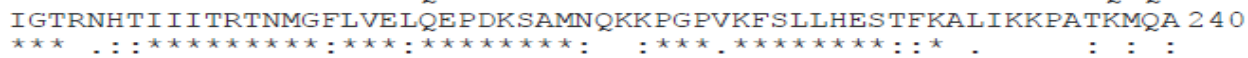

IIMEFNSSIAI 251

LIMEFNSLLAI 251

LILEFNSSLAI

LILEFNSSLAI 251

LILEFNSSLAI 
International Journal of Engineering Applied Sciences and Technology, 2020

Vol. 4, Issue 9, ISSN No. 2455-2143, Pages 241-271

Published Online January 2020 in IJEAST (http://www.ijeast.com)

\section{MINOR-NUCLEO PROTEIN}

Reston

Sudan

Zaire

Taiforest

Bundibugyo

Reston

Sudan

Zaire

Taiforest

Bundibugyo

Reston

Sudan

Zaire

Taiforest

Bundibugyo

Reston

Sudan

Zaire

Taiforest

Bundibugyo

Reston

Sudan

zaire

Taiforest

Bundibugyo

MEHSRERGRSSNMRHNSREPYENPSRSRSLSRDPNQVDRRQPRSASQIRVPNLFHRKKTD 60 MERGRERGRSRNSRADQONSTGPOFRTRSISRDKTTTDYRSSRST SOVRVPTVEHKKGTG 60 MEASYERGRPRAARQHSRDGHDHHVRARSSSRENYRGEYRQSRSA.SQVRVPTVFHKKRVE 60 MEVVHERGRSRISRQNTRDGPSHLVRARSSSRASYRSEYHTPRSASQIRVPTVFHRKKTD 60 MDSFHERGRSRT IRQSARDGPSHQVRTRSSSRDSHRSEYHTPRSSSQVRVPTVFHRKRTD 60

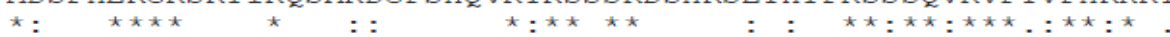

ALIVPPAPKD ICPTLKKGFLCDSKFCKKDHQLDSLNDHELLLLIARRTCGI IESNSQITS 120 TLTVPPAPKDVCPTLRKGFLCDSNFCKKDHQLESLTDRELLLL IARKTCGSTDSSLNIAA 120 PLTVPPAPKD ICPTLKKGFLCDSSFCKKDHOLESLTDRELLLLIARKTCGSVEOOLNITA 120 LLTVPPAPKDVCPTLKKGFLCDSNFCKKDHQLESLTDRELLLLIARKTCGSTEQQLSIVA 120 SLTVPPAPKD ICPTLRKGFLCDSNFCKKDHQLESLTDRELLLLIARKTCGSLEQQLNITA 120

PKDMRLANPTAEDFSQGNSPKLTLAVLLQIAEHWATRDLRQIEDSKLRALLTLCAVLTRK 180 PKDLRLANPTADDFKQDGSPKLTLKLLVETAEFWANQNINEVDDAKLRALLTLSAVLVRK 180 PKDSRLANPTADDFOOEEGPKITLLTLIKTAEHWARODIRTIEDSKLRALLTLCAVMTRK 180 PKDSRLANPIAEDFQQKDGPKVTLSMLIETAEYWSKQDIKNIDDSRLRALLTLCAVMTRK 180 PKDTRLANPIADDFQQKDGPKITLLTLLETAEYWSKQDIKGIDDSRLRALLTLCAVMTRK 180

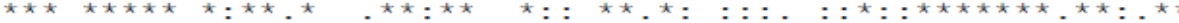

FSKSQLGLLCETHLRHEGLGQDQADSVLEVYQRLHSDKGGNFEAALWQQWDRQSL IMFIS 240 FSKSQLSQLCESHLRRENLGQDQAESVLEVYQRLHSDKGGAFEAALWQQWDRQSLTMFIS 240 FSKSQLSLLCETHLRREGLGQDQAEPVLEVYQRLHSDKGGSFEAALWQQWDRQSL IMF IT 240 FSKSQLSLLCESHLRREGLGQDQSESVLEVYORLHSDKGGNFEAALWOOWDROSL IMFIT 240 FSKSQLSLLCESHLRREGLGQDQSESVLEVYQRLHSDKGGNFEAALWQQWDRQSL IMFIT 240

Sudan

Reston

Zaire

Taiforest

Bundibugyo

Sudan

Reston

Zaire

Taiforest

Bundibugyo

Sudan

Reston

Zaire

Taiforest

Bundibugyo

Sudan

Reston

zaire

Taiforest

Bundibugyo

Sudan

Reston

Zaire

Taiforest

Bundibugyo

Sudan

Reston

Zaire

Taiforest

Bundibugyo

AFINIALQIPCESSSVVTSGIDATYPAQ AFLHVALQLSCESSTVVISGLRLLAPPSVNEGLPPAPGEYTWSEDSTTAFLNIALQLPCESSAVVVSGLRTLVPQS DNEEASTNPGTCSWSDEGTPAFLNIALQLPCESSSVVI SGLRML I PQSEATEVVT PSETCTWSEGGSSH AFLNIALOLPCESSSVVI SGLRLLVPOSEDTETSTYTETRAWSEEGGPH

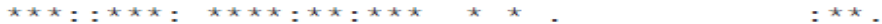

\section{NUCLEO-PROTEIN}

MDKRVRGSWALGGQSEVDLDYHKI LTAGLSVQQGIVRQRVI PVYVVS DLEGICQH I I QAF 60 MDRGTRRIWVSQNQGDTDLDYHKI LTAGLTVQQGIVRQKI I SVYLVDNLEAMCQLVIQAF 60 MDSRPQKI WMAPS LTESDMDYHKI LTAGLSVQQGIVRQRVI PVYQVNNLEE ICQL I I QAF 60 MESRAHKAWMT HTA SGFETDYHKI LTAGLSVQQG I VRQRVIQVHQVTNLEE I CQL I I QAF 60 MDPRPIRTWMMHNT SEVEADYHK I LTAGLSVQQG IVROR I I PVYO I SNLEEVCOL I IOAF 60

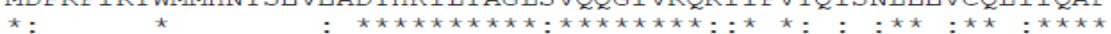

EAGVDFQDNADSFLLLLCL HHAYQGDHRLFLKS DAVQYLEGHGFRFEVREKENVHRLDEL 120 EAGIDFQENADSFLLMLCLHHAYQGDYKLFLESNAVQYLEGHGFKFELRKKDGVNRLEEL 120 EAGVDFOESADSFLLMLCLHHAYQGDYKLFLESGAVKYLEGHGFRFEVKKRDGVKRLEEI 120 EAGVDFQESADSFLLMLCLHHAYQGDYKQFLESNAVKYLEGHGFRFEVRKKEGVKRLEEL 120 EAGVDFQDSADSFLLMLCLHHAYQGDYKQFLESNAVKYLEGHGFRFEMKKKEGVKRLEEL 120

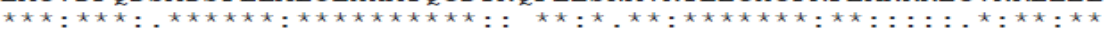

LPNVTGGKNLRRTLAAMPEEETTEANAGQFLSFASLFLPKLVVGEKACLEKVQRQIQVHA 180 LPAATSGKNIRRTLAALPEEETTEANAGOFLSFASLFLPKLVVGEKACLEKVOROIOVHA 180 LPAVSSGKNI KRTLAAMPEEETTEANAGQFLSFAS LFLPKLVVGEKACLEKVQRQIQVHA 180 LPAASSGKSIRRTLAAMPEEETTEANAGQFLSFAS LFLPKLVVGEKACLEKVQRQ IQVHS 180 LPAASS GKNI KRTLAAMPEEETTEANAGQFLSFASLFLPKLVVGEKACLEKVQRQ IQVHA 180

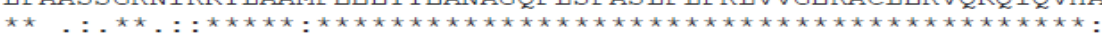

EQGL IQYPTSWQSVGHMMVI FRLMRT NF L I KFL L I HQGMHMVAGH DANDTVISNSVAOAR 240 EQGLIQYPTAWQSVGHMMVI FRLMRT NF L I KYLL I HQGMHMVA GH DANDAVIANSVAQAR 240 EQGL IQYPTAWQSVGHMMVI FRLMRT NF L I KFLL I HQGMHMVA GH DANDAVISNSVAQAR 240 EQGL IQYPTAWQSVGHMMVI FRLMRT NF L I KFL L I HQGMHMVA GH DANDAVIANSVAQAR 240 EQGL IQYPTSWQSVGHMMVI FRLMRTNF L I KFL L I HQGMHMVAGHDANDAVIANSVAQAR 240

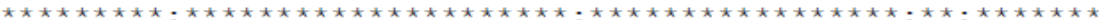

FSGLLIVKTVLDH ILQKT DLGVRLHPLARTAKVKNEVSSFKAALGSLAKHGEYAP FARLL 300 FSGLLIVKTVLDH I LQKTDQGVRL HPLARTAKVRNEVNAFKAALS SLAKHGEYAPFARLL 300 FSGLLIVKTVLDH ILQKTERGVRLHPLARTAKVKNEVNSFKAALSSLAKHGEYAPFARLL 300 FSGLL IVKTVLDH I LOKTEHGVRLHPLARTAKVKNEVNSFKAALSSLAOHGEYAPFARLL 300 FSGLIIVKTVLDHILOKTEHGVRL HPIARTAKVKNEVSSFKAALASIAOHGEYAPFARLI 300

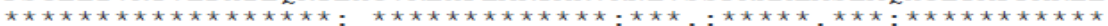

NLSGVNNLEHGLYPQLSAIALGVATAHGSTLAGVNVGEQYQQLREAATEAEKQLQQYAET 360 NLSGVNNLEHGLYPOLSAIALGVATAHGSTLAGVNVGEQYQOLREAATEAEKOLQQYAES 360 NLSGVNNLEHGLFPOLSAIALGVATAHGSTLAGVNVGEOYOOLREAATEAEKOLOOYAES 360 NLSGVNNLEHGLFPOLSA IALGVATAHGSTLAGVNVGEOYOQLREAATEAEKOLOKYAES 360 NLSGVNNLEHGLFPQLSA IALGVATAHGSTLAGVNVGEQYQQLREAATEAEKQLQKYAES 360

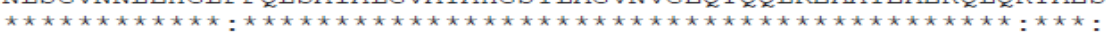


International Journal of Engineering Applied Sciences and Technology, 2020

Vol. 4, Issue 9, ISSN No. 2455-2143, Pages 241-271

Published Online January 2020 in IJEAST (http://www.ijeast.com)

Sudan

Reston

Zaire

Taiforest

Bundibugyo

Sudan

Reston

Zaire

Taiforest

Bundibugyo

Sudan

Reston

zaire

Taiforest

Bundibugyo

Sudan

Reston

Zaire

Taiforest

Bundibugyo

Sudan

Reston

zaire

Taire

Bundibugyo

Sudan

Reston

Zaire

Taiforest

Bundibugyo

Sudan

Reston

zaire

Taiforest

Bundibugyo

Reston

Sudan

zaire

Taiforest

Bundibugyo

Reston

Sudan

rair

Taiforest

Bundibugyo

Reston

Sudan

zaire

rairorest

Reston

Rudan

zaire

Taiforest

Bundibugyo

Reston

Sudan

zaire

Taiforest

Reston

Sudan

zaire

Taiforest

Bundibugyo

RELDNL GLDEQEKKILMS FHQKKNEISFQQTNAMVTLRKERLAKLTEAITTASKI KVGDR 420 RELDSL GL DDQERRILMNFHQKKNEISFQQTNAMVTLRKERLAKL TEAITLASRPNLGSR 420 RELDHLGLDDOEKK I LMNFHOKKNEI SFOQTNAMVTLRKERLAKL TEAITAASIPKTSGH 420 RELDHL GL DDQEKKILKD FHQKKNEISFQQTTAMVTLRKERLAKLTEAITSTSLLKTGKQ 420 RELDHL GLDDQEKKILKD FHQKKNEISFQQTTAMVTLRKERLAKL TEAITSTS ILKTGRR 420

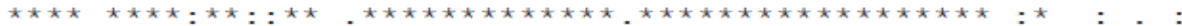

YPDDNDIPFPGPIYDETHPNPSDDNPDDSRDTTIPGGVVDPYDDESNNYPDYEDSAEGTT 480 QDDGNE I PFPGPISNN PDODHLEDDPRDSRDTI IPNGAIDPEDGDFENYNGYHDDEVGTA 480 YDDDDDIPFPGPINDDDNPGHODDDPTDSODTT IPDVVVDPDDGSYGEYQSYSENGMNAP 480 YDDDNDI P F GP INDNEN SEQODDDPTDSQDTT I PDI IVDPDDGRYNNYGDYPSE TANAP 480 YDDDNDIPFPGPINDNENSGQNDDDPTDSQDTTIPDVIIDPNDGGYNNYSDYANDAASAP 480

GDLDLFNLDDDDDDSOPGPPDRGOSKERAARTHGLQ-DPTLDGA-------KKVPELTPG 532 GDIVLFDLDDHEDDNKAFEPQDSSPOS-- - - - - - - OREIER----ERI I HPPPGNNKD 526 GDIVLFDLDDHEDDNKAFEPQDSSPQS----------QREIER----ERII HPPPGNNKD 526 EDIVLFDLEDGDEDDHRPSSSSENNNKHSL--TGTDSNKTSNWNRNP----TNMPKKDS-533 EDLVLFDLEDGDEDDHRPSSSSENNNKHSL--TGTDSNKTSNWNRNP----TNMPKKDS- 533
DDLVLFDLEDEDDADN PAQNTPEKNDRPAT--TKLRNGQDQDGNQGE----TASPRVAP-533 $\star \star \star \star \star * \star * \cdots:$

SHQPG--NLHIT---KP-GSNTNQPQGNMSSTLQSMTPIQEESEPDDQKDDDDESLTSLD 58 DNRASDNNQQSADSEEQGGQYNWHRGPERTTANRRLS PVHEEDTLMDQGDDDPSSLPPLE 586 ------HRT IHHASAPL TDNDRRNE PSGSTSPRMLT PINEEADPLDDADDETSSIPPLE 586 TQNNDNPAQRAQEYARDNIODTPTPHRALTPISEETGSNGHNEDDIDSIPPLE 586 -- - - NQYRDKPMPQVQDRSENHDQTLQTQSRVLTPISEEADPSDHNDGDNESIPPLE 586

SEGDEDVESVSGENNPTVAPPAPVYKDTGVDTNQQNGPSNAVDGQGSESEALPINPEKGS 646 SDDDDASSSQQDPDYTAVAP PAPVYRSAEAHEP PHKS SNEPAETSQLNEDPDIGQSKSMQ 646 SDDEEQDRDGTSNRTPTVAP PAPVYRDHSEKKELPQDEQQDQDHTQEARNQDSDNTQSEH 646 SDDEEQDRDGTSNRTPTVAP PAPVYRDHSEKKELPQDEQQDQDHTQEARNQDSDNTQSEH 646 SDEENNTETTITTTKNTTAP PAPVYRSNSEKEPLPQEKSQKQPNQVSGSENTDNKPHSEQ 646

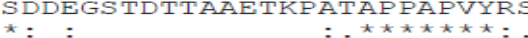

ALEETYYHLLKTQGPFEA INYYHLMS DEPIAFSTESGKEYI FPDSLEEAYP PWLSEKEAL 706 KLEETYHHLLRTQGPFEA INYYHMMKDEPVIFSTDDGKEYTYPDSLEEAYPPWLTEKERL 706 SEEEMYRHILRSQGPFDAVLYYHMMKDE PVVFSTSDGKEYTYPDS LEEEYPPWLTEKEAM 706 SVEEMYRHILQTQGPFDAILYYYMMTEEPIVFSTSDGKEYVYPDSLEGEHP PWLSEKEAL 706 SIAEMYQH ILKTQGPFDA ILYYHMMKEEPI IFSTSDGKEYTYPDSLEDEYPPWLSEKEAM 706

EKENRYLVIDGQQFLWPVMSLQDKFLAVLQHDDKENRYIYINNQQFFWPVMS PRDKFLAILQHHQ NEENRFVTLDGQQFYW PVMNHKNKFMAI LQHHQ NEDNRF ITMD DQQFYW PVMN HRNKFMAI LQHHK NEDNRFITMDGQQ

\title{
POLYMERASE COMPLEX PROTEIN
}

\begin{abstract}
MYNNKLKVCSGPETTGWI SEOLMTGKI PVTDIFIDIDNKPDQMEVRIK 48 -MTTRTKGRGHTAATTQNDRMPGPELSGWISEQLMTGRIPVSDIFCDIENNPGLCYASQM 59 -MTTRTKGRGHTAATTQNDRMPGPELSGWISEQLMTGRIPVSDIFCDIENNPGLCYASQM 59 MTSNRARVTYNPPPTTTGTRSCGPELSGWISEQLMTGKIPITDIFNEIETLPSISPSIHS 60

PSSRSSTRTCTSSSQTEVNYVPLLKKVEDTLTMLVNATSRQNAAIEALENRLSTLESSLK 108 SKNPKT TRKS DKQVQT DDASSLITEEVKAA INSVISAVRRQTNAIES LEGRVTTLEASLK 108 QQTKPN PKTRNSQTQT DPICNHSFEEVVQTLASLATVVQQQTIASESLEQRITSLENGLK 119 RPKNTAPRTRNTQTQT DPVCNHNFEDVTQALTSLTNVIQKQALNLES LEQRIIDLENGLK 120 KIKTPSVQTRSVQTQTDPNCNHDFAEVVKMLTSLTLVVQKQTLATESLEQRITDIEGSLK 120
\end{abstract}

PIQDMGKVISSLNRSCAEMVAKYDLIVMTTGRATSTAAAVDAYWKEHKQPPPGPALYEEN 168 PVQDMAKTISSLNRSCAEMVAKYDLIVMTTGRATATAAATEAYWNEHGQAPPGPSLYEDD 168 PVYDMAKTISSLNRVCAEMVAKYDLLVMTTGRATATAAATEAYWAEHGQPPPGPSLYEES 179 PMYMAKVISALNRSCAEMUKYDLLVMTGRATATAAATAYWEEHGQPPGESLYEES 180 PVSEITKIVSALNRSCAEMVAKYDLIVMTTGRATATAAATEAYWAEHGRPPPGPSLYEED 180

ALKGKIDDPNSYVPDAVQEAYKNLDSTSTLTEENFGKPYISAKDLKEIMYDHLPGFGTAF 228 AIKAKLKDPNGKVPESVKQAYINLDSTSALNEENFGRPYISAKDLKEIIYDHLPGFGTAF 228 AIRGKIESRDETVPOSVREA FNNINSTTSITEENFGKPDISAKDI.RN IMYDHIPGFGTAF 239 AIRGKINKOEDKVPKEVOEAFRNLDSTSSITEENFGKPDISAKDLRDIMYDHLPGFGTAF 240 AIRTKIGKQGDMVPKEVQEAFRNLDSTALITEENFGKPDISARDLRNIMYDHIPGFGTAF 240

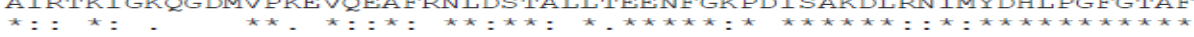

HQLVQVICKIGKDNNLIDTIHAEFQASLADGDSPQCALIQITKRVPIFQDVPPPIIHIRS 288 HQLVQVICKIGKDNNIIDIIHAEFQASLAEGDS PQCAIIQITKRI PAFQDASPPIVHIKS 288 HQIVQVICKIGKDSNSLDIIHAEFQASLAEGDSPQCAIIQITKRVPI FQDAAPPVIHIRS 299 HQLVQVICKLGKDNSAIDI IHAEFQASLAEGDSPQCAIIQITKRI PIFQDATPPT IHIRS 300 HQLVQVICKIGKDNSSIDVIHAEFQASLAEGDSPQCAIIQITKRIPIFQDAAPPVIHIRS 300

RGDIPRACQKSLRPAPPSPKIDRGWVCLFKMQDGKTLGLKI RGDIPKACQKSLRPVPPSPKIDRGWVCIFQFQDGKALGLKI RGDIPRACQKSIRPVPPSPKIDRGWVCVFQLQDGKTLGLKI RGDIPRACQKSLRPVPPSPKIDRGWVCIFQIQDGKTLGLKI

RGDIPKACQKSIRPVPPSPKIDRGWVCIFQIQDGKTLGLKI 341 
International Journal of Engineering Applied Sciences and Technology, 2020

Vol. 4, Issue 9, ISSN No. 2455-2143, Pages 241-271

Published Online January 2020 in IJEAST (http://www.ijeast.com)

\section{SECOND SECRETED GLYCO PROTEIN}

Taiforest Bundibugyo zaire Reston Sudan

Taiforest Bundibugyo Zaire Reston Sudan

Taiforest Bundibugyo zaire Reston Sudan

Taiforest Bundibugyo Zaire Reston Sudan

\begin{abstract}
-MGASGILQLPRERFRKTSFFVWVIILFHKVFS IPLGVVHNNTLQVSDIDKFVCRDKLSS 59 -MVTSGILQLPRERFRKTSFFVWVIILFHKVFP I PLGVVHNNTLQVSDIDKLVCRDKLSS 59 -MGVTGILQLPRDRFKRTSFFLWVIILFQRT FS I PLGVI HNST LQVS DVDKLVCRDKLSS 59 MGSGYQLLQL PRERFRKTSFLVWVI I LFQRA ISMPLG IVTNSTLKATEI DQLVCRDKLSS 60 -MGGLSLLQLPRDKFRKSSFFVWVIILFQKAFSMPLGVVTNSTLEVTEIDQLVCKDHLAS 59
\end{abstract}

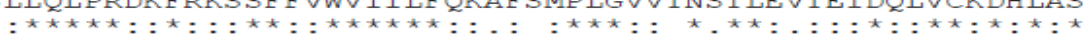

TSQLKSVGLNLEGNGVAT DVPTATKRWGFRAGVPPKVVNCEAGEWAENCYNLAIKKVDGS 119 TSQLKSVGLNLEGNGVATDVPTATKRWGFRAGVPPKVVNYEAGEWAENCYNLDIKKADGS 119 TNQLRSVGLNLEGNGVAT DVPSATKRWGFRSGVPPKVVNYEAGEWAENCYNLEIKKPDGS 119 TSQLKSVGLNLEGNGIATDVPSATKRWGFRSGVPPKVVSYEAGEWAENCYNLEIKKS DGS 120 TDQLKSVGLNLEGSGVSTDIPSATKRWGFRSGVPPKVVSYEAGEWAENCYNLEIKKPDGS 119

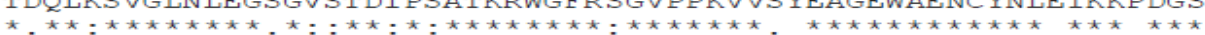

ECLPEAPEGVRDFPRCRYVHKVSGTGPCPGGLAFHKEGAFFLYDRLASTIIYRGTTFAEG 179 ECLPEAPEGVRGFPRCRYVHKVSGTGPCPEGYAFHKEGAFFLYDRLASTIIYRSTTFSEG 179 ECLPAAPDGIRGFPRCRYVHKVSGTGPCAGDFAFHKEGAFFLYDRLASTVIYRGTTFAEG 179 ECLPLPPDGVRGFPRCRYVHKVQGTGPCPGDLAFHKNGAFFLYDRLASTVIYRGTTFAEG 180 ECLPPPPDGVRGFPRCRYVHKAQGTGPCPGDYAFHKDGAFFLYDRLASTVIYRGVNFAEG179

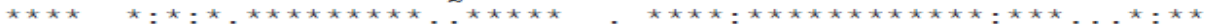

VIAFLILPKARKDFFQSPPLHEPANMTTDPSSYYHTTTINYVVDNFGTNTTEFLFQVDHL 239 VVAFL I PETKKDF EQSP PL HEPANMTT DPSSYYHTVTLNYVADNFGTNMTNFLFQVDHL 239 VVAFLILPQAKKDFFSSHPLREPVNATEDPSSGYYSTTIRYQATGFGTNETEYLFEVDNL 239 VVAFLILSEPKKHFWKATPAHEPVNTTDDSTSYYMTLTLSYEMSNFGGNESNTLFKVDNH 240 VIAFLILAKPKETFLQSPPIREAVNYTENTSSYYATSYLEYEIENFGAQHSTTLFKIDNN 239

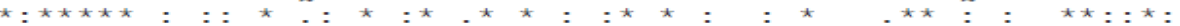

TYVQLEARFT PQFLVLLNET IYSDNRRSNTTGKLI WK INPTVDTSMGEWAFWENKKL HKN 299 TYVQLE PRFT PQFLVOLNET IYTNGRRSNT TGTLIWKVNPTVDTGVGEWAFWENKKLHKN 299 TYVOLESRFTPQFLLOLNET IYTSGKRSNTT GKLIWKVNPE I DTT IGEWAFWETKKPH - - 297 TYVQLDRP HT PQFLVQLNETLRRNNRLSNS TGRLTWT LDPKIEPDVGEWAFWETKKLFPT 300 TFVRLDRPHTPQFLFQLNDT IHLHQQLSNTTGRL I WT LDAN INAD I GEWAFWENKKS LRT 299

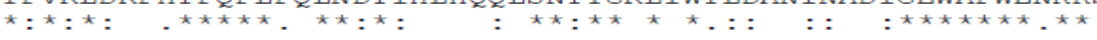

Reston

Sudan

Taiforest

Bundibugyo

zaire

Reston

Sudan

\section{SMALL SECRETED GLYCO PROTEIN}

Taiforest
Bundibugyo

zaixe

Reston
Sudan

Taiforest

Zaire

Reston

Taiforest

ugyo

Reston

Taiforest

Bundibugyo

Reston
Sudan

Taiforest

Zaire

Resto
sudan

Taiforest

Raire

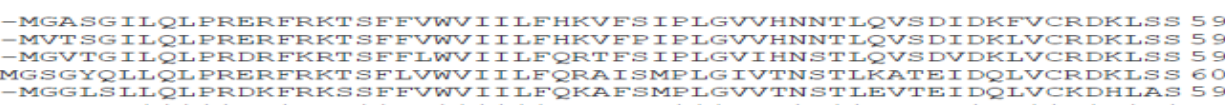

TSQLKSVGLNLEGNGVATDVPTATKRWGFRAGVPPKVVNCEAGEWAENCYNLAIKKVDGS 119 TSRLKSVGINLEGNGVATDVPTATKRWGFRAGVPPKVVNYEAGEWAENCYNIDIKKADGS 119

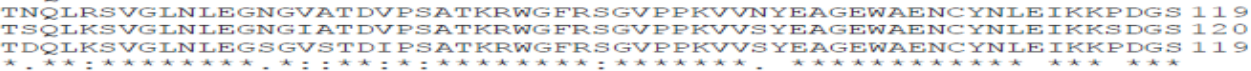
ECIPEAPEGVRDFPRCRYVHKVSGTGPCPGGLAFHKEGAFFIYDRLASTIIYRGTTEAEG 179 ECIPEAPEGVRGFPRCRYVHKVSGTGPCPEGYAFHKEGAFFIYDRIASTIIYRSTTFSEG 179 ECIPAAPDGIRGFPRCRYVHKVSGTGPCAGDFAFHKEGAFFIYDRLASTVIYRGTTFAEG 179 ECIPPPPDGVRGFPRCRYVHKAQGTGPCPGDYAFHKDGAFFIYDRLASTVIYRGVNFAEG 179 VIAFIIIPKARKDFFOSPPIHEPANMTTDPSSYYHTTTINYVVDNFGTNTTEFIFEVDHI 239 VVAFIILPRAKKDEFSSHPLREPVNATEDPSSGYYSTTIRYQATGEGTNETEYLFEVDNI 239 VVAFIIISEPKKHFWKATPAHEPVNTTDDSTSYYMTITISYEMSNEGGNESNTIFKVDNH 240
VIALIILAKPKETELQSPPIREAVNYTENTSSYYATSYIEYIENEGAQHSTTLFIDNN 239 TYVQLEARFTPQFIVLINETIYSDNRRSNTTGKLIWKINPTVDTSMGEWAFWENKKTSOK 299 TYVOLESRFT POFLIOLNETIYTS GKRSNTT GKII WKVNPEIDTTIGEWAFWETKKTSLE 299 TEVRIDRPHTPQFIFQINDTIHIHQQISNTTGRIIWTIDANINADIGEWAFWENKKISPN 299

PFQVKSCLSYLYQKPRTRSITRQRRSLIPSPPTTTQPKTTKNWFQRIPLQWFRCKTSRER 35 S PFQVKSCISYLYQKPRTRSITRQRRSIIPSPPTTTQPKTTKNWFQRI PIQWFRCKTSRER 359 KFAVKSCISQLYQTEPKTSVVRVRREIIPTQGPTQQIKTTKSWIQKIPIQWFKCTVKEGK 359 NEMEKTCI SKFHQPTPTTPQIRARREISKEKLATTHPPTTPSWFQRIPIQWFQCSIRDGQ360 
International Journal of Engineering Applied Sciences and Technology, 2020

Vol. 4, Issue 9, ISSN No. 2455-2143, Pages 241-271

Published Online January 2020 in IJEAST (http://www.ijeast.com)

Taiforest Bundibugyo Zaire

Reston

sudan

\begin{tabular}{|c|c|}
\hline TQCQPQ---.-- & 365 \\
\hline TQCRPHPQTQSPQL & 373 \\
\hline LQCRI $-1--1-0$ & 364 \\
\hline 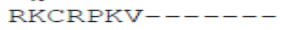 & 367 \\
\hline QHCRLRIRQKVEE- & 372 \\
\hline
\end{tabular}

\section{SPIKE GLYCO-PROTEIN}

-MGVTGILQLPRDRFKRTSFFLWVIILFQRTFS IPLGVI HNSTLQVSDVDKLVCRDKLSS 59 -MGASGILQLPRERFRKT SFFVWVIILFHKVFS I PLGVVHNNTLQVSDI DKFVCRDKLSS 59 -MVTSGILQLPRERFRKT SFFVWVIILFHKVFP I L LVVHNNT LQVSDI DKLVCRDKLSS 59 MGSGYOLIOLPRERFRKTSFIVWVI I LFORA I SMPLG IVTNSTLKATEI DQLVCRDKISS 60 -MGGISII OIPRDKFRKSSFFVTVIIIFOKAFSMPIGVVTNSTIEVTPIDOIVCKDHIAS 59

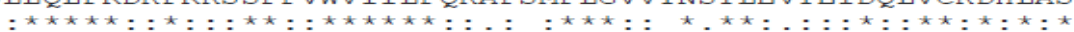

Bundibugyo

Reston

Sudan

Zaire

Taiforest

Bundibugyo

Reston

Sudan

\section{zaire}

Taiforest

Bundibugyo

Reston

sudan

zaire

Taiforest

Bundibugyo

Reston

Reston
Sudan

zaire

Taiforest

Bundibugyo

Reston

sudan

Zaire

Taiforest

Bundibugyo

Reston

sudan

zaire

Taiforest

Bundibugyo

Reston

Sudan

TNQLRSVGLNLEGNGVATDVPSATKRWGFRSGVPPKVVNYEAGEWAENCYNLEIKKPDGS 119 TSQLKSVGLNLEGNGVAT DVPTATKRWGFRAGVPPKVVNCEAGEWAENCYNLAIKKVDGS 119 TSQLKSVGLNLEGNGVAT DVPTATKRWGFRAGVPPKVVNYEAGEWAENCYNLDIKKADGS 119 TSQLKSVGLNLEGNGIAT DVPSATKRWGFRSGVPPKVVSYEAGEWAENCYNLE IKKSDGS 120 TDQLKSVGLNLEGSGVSTDIPSATKRWGFRSGVPPKVVSYEAGEWAENCYNLEIKKPDGS 119

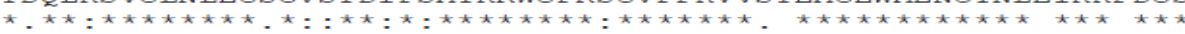

ECLPAAPDGIRGFPRCRYVHKVSGTGPCAGDFAFHKEGAFFLYDRLASTVIYRGTTFAEG 179 ECIPEAPEGVRDFPRCRYVHKVSGTGPCPGGLAFHKEGAFFLYDRLAST IIYRGTTFAEG 179 ECLPEAPEGVRGFPRCRYVHKVSGTGPCPEGYAFHKEGAFFLYDRLASTIIYRSTTFSEG 179 ECLPEAPEGVRGFPRCRYVHKVSGTGPCPEGYAFHKEGAFFLYDRLASTIIYRSTTFSEG 179 ECLPLPPDGVRGFPRCRYVHKVQGTGPCPGDLAFHKNGAFFLYDRLASTVIYRGTTFAEG 180

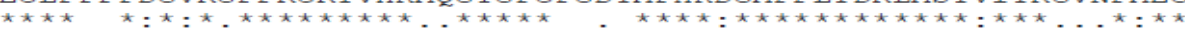

VVAFLILPQAKKDFFSSHPLREPVNATEDPSSGYYSTTIRYQATGFGTNETEYLFEVDNL 239 VIAFLILPKARKDFFOSP PLHEPANMTTDPSSYYHTTTINYVVDNFGTNTTEFLFOVDHI 239 VVAFLILPETKKDFFOSPPIHEPANMTT DPSSYYHTVTLNYVADNFGTNMTNFLFOVDHI 239 VVAFIIISEPKKHFWKATPAHEPVNTTDDSTSYYMTITISYEMSNEGGNESNTLEKVDNH 240 VTAELIISEPKK

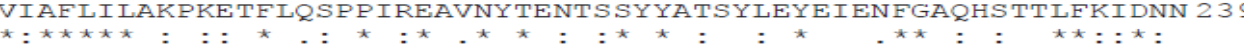

TYVQLESRFT PQFLLQLNET IYTSGKRSNTTGKLIWKVNPEIDTT IGEWAFWETKKNLTR 299 TYVQLEARFT PQFLVLLNETIYSDNRRSNTTGKLIWKINPTVDTSMGEWAFWENKKNFTK 299 TYVQLE PRFT PQFLVQLNET IYTNGRRSNTTGTLIWKVNPTVDTGVGEWAFWENKKNFTK 299 TYVQLDRP HT PQFLVQLNET LRRNNRLSNSTGRLTWT LDPKIEPDVGEWAFWETKKNFSQ 300 TFVRLDRP HT PQFLFQLNDT I HLHQQLSNTTGRL I WT LDAN INAD I GEWAFWENKKNLSE 299

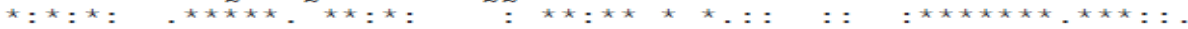

KIRSEELSFTVVSNGAKNISGOSPARTSSDPGTNTTTEDHKIMASENSSAMVOVHSOGRE 359 TLSSEELSFVPVPETQNQVLDTTATVSPPISAHNHAAEDHKELVSEDSTPVVQMQNIKGK 359 TLSSEELSVI FVPRAQDPGSNQKTKVTPTS FANNQTSKNHEDLVPED PASVVQVRDLQRE 359 QLHGENLHFQIPSTHTNNSSDQSPAGTVQGKISYHPPANNSELVPTDSPPVVSVLTAGRT 360 QLRGEELSFEALSLNETEDDDAASSRITKGRISDRATRKYSDLVPKNSPGMVPLHIPEGE 359 : $\star_{*}$.

AAVSHLTTLATISTS--P-QSLTTKPGPDNST-HNTPVYKLD-ISEATQVEQHHRRTDND 414 DTMPTTVT-----------GVPTTTPSPFPINARNTDHTKSFI GLEGPQ-ED-HSTTQPA 406 NTVPTPPP-----------DTVPT TL I PDTMEEQTTSHYEPPN ISRNHQ-ER-NNTAHPE 406 EEMSTQGLTNGETITGFTANPMTTTIAPS-------PTMT------SEV-DNNVPSEQPN 406 TTLPSQNSTEGRRVGVNTQETITETAATI--IGTNGNHMQISTIGIRPS-SSQIPSSSPT 416 
International Journal of Engineering Applied Sciences and Technology, 2020

Vol. 4, Issue 9, ISSN No. 2455-2143, Pages 241-271

Published Online January 2020 in IJEAST (http://www.ijeast.com)

\section{Zaire
Taiforest
Bundibugyo Reston \\ sudan \\ Zaire \\ Taiforest \\ Bundibugyo \\ Reston
Sudan \\ Zaire \\ Taiforest \\ Bundibugyo \\ sudan \\ zaire \\ Taiforest \\ sudan \\ zaire \\ Bundibugyo \\ Reston}

Zaire

Tai

Bundibugyo

Sudan

Reston

\section{Zaire}

Tai

Bundibugyo

Sudan

Reston

zaire

Tai

Bundibugyo

Sudan

Reston

zaire

Tai

Bundibugyo

Sudan

Reston

zaire

Tai

Bundibugyo

Sudan

Reston

zaire

Tai

Bundibugyo

Sudan

Reston

zaire

Tai

Bundibugyo

Sudan

Reston

Zaire

Tai

Bundibugyo

Sudan

Reston

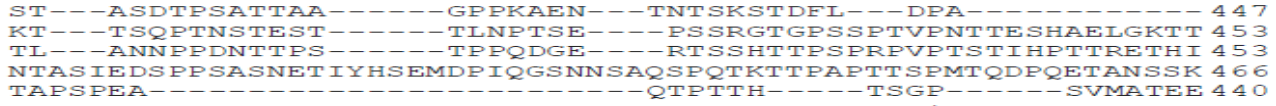

TTTSPQNHSETAG--- - - NNNTHHQDTGEESASSGKLGLITNTIAGVAGIITGGRRTR 500 PTTMTTSHDTDSN_-_-_._-_._- RPNPIDISESTEPGPITNTTRGAANLITGSRRTR 500 PGTSPGSAAGPS-- - - - - - - - - - - - - - - PTTPPGSSPGPTTEAPTLTTPENITTAVKTVLPQESTSNGLITSTVTGILGSLGLRKRSR 500

REAIVNAQPKCNPNLHYWTTQDEGAAIGLAWIPYFGPAAEGIYIEGLMHNQDGLICGLRQ 560 作 RSVRQNTANKCNPDIYYWTAVDEGAAVGLAWIPYFGPAAEGIYIEGVMHNQNGIICGIRQ 561 RQTNTKATGKCNPNLHYWTAQEQHNAAGIAWIPYFGPGAEGIYTEGLMHNQNALVCGLRQ 560 LANETTQALQLFLRATTELRTFSILNRKAIDFLIQRWGGTCHILGPDCCIEPHDWTKNIT 620

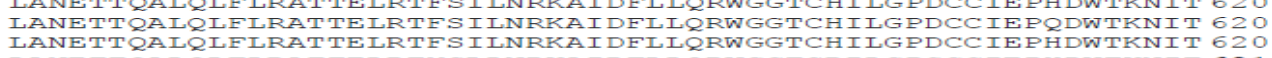
I.ANETTQAIQLFIRATTELRTYSLINRKAIDFLIRRWGGTCRILGPSCCIEPHDWTKNIT 621

DKIDQIIHDFVDKTLPDQGDNDNWWTGWRQWIPAGIGVTGVIIAVIAIFCICKFVF

DKIDQIIHDFIDKPLPDQTDNDNWWTGWRQWVPAGIGITGVIIAVIAILCICKFII

DEINQIKHDFIDNPIPDHGDDLNLWTGWRQWIPAGIGIIGVIIAIIAIICICKILC

676
676

676
676
677
676

\section{RNA DEPENDENT RNA POLYMERASE}

-MATQHTQYPDARLSSPIVLDQCDLVTRACGLYSSYSLNPQLRNCKLPKHIYRLKYDVTV 59 -MATQHTQYPDARLSSPIVLDQCDLVTRACGLYSAYSLNPQLKNCRL PKH IYRLKYDTTV 59 -MATQHTQYPDARLSS PIVLDQCDLVTRACGLYSSYSLNPQLKNCRL PKH IYRLKFDATV 59 MMATQHTQYPDARLSSPIVLDQCDLVTRACGLYSEYSLNPKLKTCRLPKHIYRLKYDTIV 60

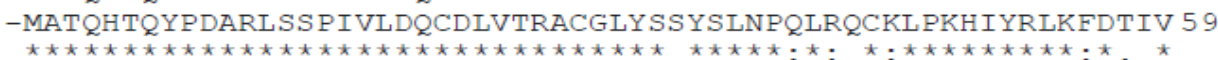

TKFLSDVPVATLPIDFIVPVLLKALSGNGFCPVEPRCQQFLDE I IKYTMQDALFLKYYLK 119 TEFLSDVPVATL PADFLVPTFLRTLSGNGSCPI DPKCSQFLEE IVNYTLQD IRFLNYYLN 119 TKFLSDVP IVTLPIDYLT PLLLRTLSGEGLCPVEPKCSQFLDEIVSYVLQDARFLRYYFR 119 LRF ISDVPVATIPI DY IAPML INVLADSKNVPLEP PCLSFLDE IVNYTVQDAAFLNYYMN 120 SKFLSDTPVATLPI DYLVPILLRSLTGHGDRPLTPTCNQFLDE I INYTLHDAAFLDYYLK 119

$$
{ }^{\star}:{ }^{\star} \cdot{ }^{\star}: .^{\star}:{ }^{\star}{ }^{\star}::^{\star}::{ }^{\star}: .{ }^{\star}:{ }^{\star}{ }^{\star}{ }^{\star}:{ }^{\star}{ }^{\star}: .^{\star}::^{\star}{ }^{\star \star}{ }^{\star}: .
$$

NVGAQEDCVDEHFQEKILSSIQGNEFLHQMFFWYDLAILTRRGRLNRGNSRSTWFVHDDL 179 RAGVHN DHVDRDFGQK IRNL I CDNEVLHQMF HWYDLA ILARRGRLNRGNNRSTWFASDNL 179 HVGVHDDNVGKNFEPKIKALIYDNEFLQQLFYWYDLAILTRRGRLNRGNNRSTWFANDDI 179 QIKTQEGVIT DQLKQN IRRV IHKNRY LSALF FWHDLA ILTRRGRMNRGNVRSTWFVTNEV 180 ATGAQDHLTN IATREKLKNE ILNNDYVHQLFFWHDLS ILARRGRLNRGNNRSTWFVHDEF 179

IDILGYGDYVFWKIPISMLPLNTQGI PHAAMDWYQASVFKEAVQGHTHIVSVSTADVLIM 239 VDILGYGDYIFWKI PLSLIPVDTQGLPHAAKDWYHESVFKEAIQGHTHIVSISTADVLIM 239 IDILGYGDYIFWKIPLSLLSLNTEGI PHAAKDWYHASIFKEAVQGHTHIVSVSTADVLIM 239 VDILGYGDYIFWKI PIALLPMNTANVPHAST DWYQPN IFKEA IQGHTHI ISVSTAEVLIM 240 IDILGYGDYIFWKI PLSLLPVTIDGVPHAAT DWYQPTLFKESI LGHSQILSVSTAEILIM 239

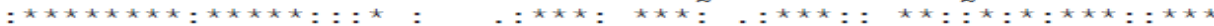

CKDLITCRFNTTLISKIAEIEDPVCSDYPNFKIVSMLYOSGDYLLSILGSDGYKIIKFIE 299 CKDIITCRFNTLLIAAVANLEDSVHSDYPLPETVSDLYKAGDYLISLLGSEGYKVIKFLE 299 CKDIITCRFNTTLIAALANLEDSICSDYPQPETISNLYKAGDYLISILGSEGYKVIKFLE 299 CKDLVTSRFNTLIIAELARLEDPVSADY PLVDNIQSLYNAGDYLLSILGSEGYKIIKYLE 300 CKDIITCRFNTSLIAS IAKLEDVDVSDYPDPSDILKIYNAGDYVISILGSEGYKIIKYLE 299 PLCLAKIOLCSKYTERKGRFITOMHLAVNHTLEEITEMRALKPSOAOKIREFHRTIIRLE 359 PLCLAKIQLCSKYTERKGRFLTQMHLAVNHTLEEITEMRALKPSQAQKIREFHRTLIRLE 359 PLCLAKIQLCSNYTERKGRFLTQMHLAVNHTLEELTGSRELRPQQ IRKVREFHQMLINLK 359
PLCLAKIQLCSNYTERKGRFLTQMHLAVNHTLEEL IEGRGLKSQQDWKMREFHRILVNLK 359 PLCLAKIQLCSQYTERKGRFLTQMHLAVIQTIRELLLNRGLKKSQLSKIREFHQLLLRIR 360 PLCLAKIQLCSKFTERKGRFLTQMHLSVINDLREL ISNRRLKDYQQEKIRDFHKILIQLQ 359

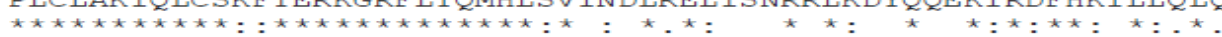

MTPQQLCELFSIQKHWGH PVLHSETAIQKVKKHATVLKALRPIVIFETYCVFKYSIAKHY 419 AT PQQLCELF SVQKHWGH PVLHSEKA IQKVKKHATVIKALRPI I I FETYCVFKYSIAKHY 419 ST PQQLCELF SVQKHWGHPVLHSEKAIQKVKKHATVIKALRPVIIFETYCVFKYSIAKHY 419 STPQQL CELFS I QKHWGH PVLHSEKAIQKVKNHATVLKALRPIIIFETYCVFKYSVAKHF 420 LSPQQFCELF SVQKHWGHPILHSEKAIQKVKRHATILKALRPNVIFETYCVFKYNIAKHY 419

FDSQGSWYSVTSDRNLTPGLNSYIKRNQFPPLPMIKELLWEFYHLDHPPLFSTKIISDLS 479 FDSQGTWYSVTSDRCLTPGLSSYIKRNQFP LPMIKELLWEFYHLDHPPLFSTKVISDLS 479 FDSQGSWYSVISDKHLTPGLHSYIKRNQFPPLPMIKDLLWEFYHLDHPPLFSTKIISDLS 479 FDSQGSWYSVISDKHLTPGLHSYIKRNQFPPLPMIKDLLWEFYHLDHPPLFSTKI ISDLS 479
FDSQGTWYSVISDRCLTPGLNSYIRRNQFPPLPMIKDLLWEFYHLDHPPLFSTKIISDIS 480 FDSQGTWYSVISDRNLTPGLNSFIKRNHFPSLPMI KDLLWEFYHLNHPPLFSTKVISDLS 479 
International Journal of Engineering Applied Sciences and Technology, 2020

Vol. 4, Issue 9, ISSN No. 2455-2143, Pages 241-271

Published Online January 2020 in IJEAST (http://www.ijeast.com)

Zaire

Tai

Bundibugyo

Sudan

Reston

Zaire

Tai

Bundibugyo

Sudan

Reston

\section{zaire}

Tai

Bundibugyo

Sudan

Reston

\section{zaire}

Tai

Bundibugyo

Sudan

Reston

\section{$\underset{\text { Tair }}{\text { Tai }}$}

Tai

Sudan

Reston

\section{zaire}

Bundibugyo

Sudan

zaire

Tai

Bundibugyo

Sudan

Reston

\section{Zaire}

Tai

Bundibugyo

sudan

zaire

Tair

Buindibugyo

Sudan

Reston

\section{Zaire}

Tai

Bundibugyo

Sudan

Reston

Zaire

Tai

Sudan
Reston

zaire

Tai

Sudan
Reston

zaire

Tai

Bundibugyo

Sudan
Reston
IFIKDRATAVERTCWDAVFE PNVLGYNP PHKFSTKRVPEOFLEOENFS IENVLSYAOKLE 539 IFIKDRATAVEKTCWDAVFE PNVLGYNP PNKFATKRVPEQFLEQENFS IESVLHYAQRLE 539 IFIKDRATAVEKTCWDAVFE PNVLGYSP PNKFSTKRVPEQFLEQENFS I DSVLTYAQRLD 539 IFIKDRATAVEQTCWDAVFE PNVLGYSPPYRFNTKRVPEQFLEQEDFSIESVLQYAQELR 540 IFIKDRATAVEOTCWDAVFE PNVLGYNP PNKFSTKRVPEOFLEOEDFSIESVLNYAQELH 539

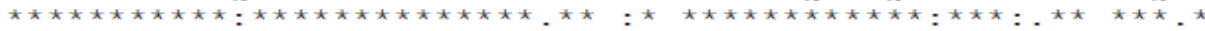

YLLPQYRNFSFSLKEKELNVGRTFGKLPYPTRNVQTLCEALLADGLAKAFPSNMMVVTER 599 YLLPEYRNFS FSLKEKELNIGRAFGKLPYPTRNVQTLCEALLIADGLAKAFPSNMMVVTER 599 YLLPQYRNFS FSLKEKELNVGRAFGKLPYPTRNVQTLCEALLADGLAKAFPSNMMVVTER 599 YLLPQNRNFS FSLKEKELNVGRT F GKLPYLTRNVQTLCEALLADGLAKAFP SNMMVVTER 600 YLLPQNRNFS FSLKEKELNIGRTFGKLPYLTRNVQTLCEALLADGLAKAFPSNMMVVTER 599

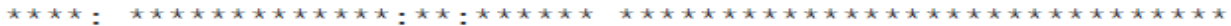

EQKESLLHQASWHHTS DDFGEHATVRGSSFVTDLEKYNLAFRYEFTAPF IEYCNRCYGVK 659 EQKESLLHQA SWHHTS DDFGENATVRGSSFVTDLEKYNLAFRYEFTAPF IEYCNRCYGVR 659 EOKESLLHQA SWHHTSDDFGENA TVRGSSFVTDLEKYNLAFRYEFTAPF IEYCNRCYGVK 659 EQKESLLHQA.SWHHT DDFGEHATVRGSSFVTDLEKYNLAFRYEFTAPF IKYCNQCYGVR 660 EQKESLLHQA SWHHTSDDFGENATVRGSSFVTDLEKYNLAFRYEFTAPF IEYCNHCYGVR 659

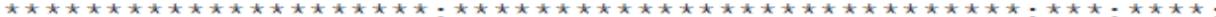

NVFNWMHYTI PQCYMHVSDYYNPP HNLTLENRDNPPEGPSSYRGHMGGIEGLQQKLWTSI 719 NLFNWMHYTI PQCY I HVS DYYNP PHGVS LENRENP PE GPSSYRGHLGGIEGLQQKLWTS I 719 NLFNWMHYTI PQCY I HVS DYYNP PHGVS LENREDP PE GPS SYRGHLGGIEGLOQKLWTS I 719 NVF DWMHF L I PQCYMHVS DYYNP PHNVTLENREYP PEGPSAYRGHLGGIEGLQQKLWTS I 720

NVFNWMHYLIPQCYMHVS DYYNP PHNVNLSNREYP PEGPSSYRGHLGGIEGLQQKLWTSI 719

SCAQISLVEIKTGFKLRSAVMGDNQCITVLSVFPLETDADEQEQS AEDNAARVAASLAKV 779 SCAQISLVEIKTGFKLRSAVMGDNQC ITVLSVF PLETESSEQELSSEDNAARVAASLAKV 779 SCAQISLVEIKTGFKLRSAVMGDNQC ITVLSVF PLET DSNEQEHSSEDNAARVAASLAKV 779 SCAQISLVEIKTGFKLRSAVMGDNQCITVLSVF PLES SPNEQERCAEDNAARVAASLAKV 780 SCAQISLVEIKTGFKLRSAVMGDNQCITVLSVE PLKT DPEEQEQSAE DNAARVAASLAKV 779

TSACGIFLKPDETFVHSGFIYFGKKQYLNGVQLPQSLKTATRMAPLSDAIFDDLQGTLAS 839 TSACGIFLKPDETFVHSGFIYFGKKQYLNGVQLPQSLKTATRIAPLSDAIFDDLQGTLAS 839 TSACGIFLKPDETFVHSGFIYFGKKQYLNGVQLPQSLKTATRIAPLSDAIFDDLQGTLAS 839 TSACGIFLKPDETFVHSGFIYFGKKQYLNGIQLPQSLKTAARMAPLSDAIFDDLQGTLAS 840 TSACGI FLKPDETFVHSGFIYFGKKQYLNGVQLPQSLKTAARMAPLSDAIFDDLQGTLAS 839

IGTAFERSISETRHIFPCRITAAFHTFFSVRILQYHHLGFNKGFDLGQLTLGKPLDFGTI 899 IGTAFERSISETRHVVPCRVAAAFHTFFSVRIIOYHHIGFNKGTDIGOLSLSKPLDFGTI 899 IGTAFERS ISETRHVYPCRVVAAFHTFFSVRILOYHHLGFNKGTDLGQLSLSKPLDFGTI 899 IGTAFERSISETRHILPCRVAAAFHTYFSVRILQHHHLGFHKGSDLGQLAINKPLDFGTI 900 IGTAFERA ISETRHILPCRIVAAFHTYFAVRILQYHHLGFNKGIDLGQLSLSKPLDYGTI 899

SLALAVPQVLGGLSFLNPEKCFYRNLGDPVTSGLFQLKTYLRMIEMDDLFLPLIAKNPGN 959 TLALAVPQVLGGLSFLNPEKCFYRNLGDPVTSGLFQLKTYLQMIHMDDLFLPIIAKNPGN 959 TLALAVPQVLGGLSFLNPEKCFYRNLGDPVTSGLFQLRTYLQMINMDDLFLPLIAKNPGN 959 ATLNPEKCLYRNIG TLTLAVPQVLGGLSFLNPEKCFYRNFGDPVTSGLFQLRVYLEMVNMKDLFCPLISKNPGN 959

CTAIDFVLNPSGLNVPGSQDLTSFLRQIVRRTITLSAKNKLINTLFHASADFEDEMVCKW 1019 CSAIDFVLNPSGLNVPGSQDLTSFLRQIVRRTITLSAKNKLINTLFHSSADLEDEMVCKW 1019 CSAIDFVLNPSGLNVPGSQDLTSFLRQIVRRTITISAKNKLINTLFHSSADLEDEMVCKW 1019 CSAIDFVLNPGGLNVPGSQDLTSFLRQIVRRSITLSARNKLINTLFHA.SADLEDELVCKW 1020 CSAIDFVLNPSGLNVPGSQDITSFLRQIVRRSITLTARNKLINTLFHASADLEDEMVCKW 1019 LLSSTPVMSRFAADIFSRTPSGKRLQILGYLEGTRTLLASKIINNNTETPVLDRLRKITL 1079 LLSSTPVMSRFAADIFSRTPSGKRLQILGYLEGTRTLLASKIINHNTETPILDRLRKITL 1079 LINSTP LLSSTP LISSNPVMSRFAADIFSRTPSGKRLQILGYLEGTRTLLASKIINNNSETPVLDKLRKITL 1079 QRWSLWFSYLDHCDNILAEALTQITCTVDLAQILREYSWAHILEGRPIIGATLPCMIERF 1139 QRWSLWFSYLDHCDQVLADALIKVSCTVDLAQI LREYTWAH ILEGRQLIGATLPCMIEQF 1139 QRWNLWESYLDHCDPALMEA IQPIKCTVDIAQIIREYSWAHILDGRQIIGATIPCIPEQF 140
QRWNLWFSYLDHCDQLLADALQKISCTVDLAQILREYTWSHILEGRSIIGATLPCMVEQF 139 *x* KVFWLKPYEQCPQCSNAKQPGGKPFVSVAVKKHIVSAWPNASRISWTIGDGIPYIGSRTE 1199
NVIWLKPYEHCKCAKSANPKGEPFVSIIKKHVVSAWPDQSRISWTIGDGIPYISRTE 199 QTTWLKPYEQCVECSSTN--NSSPYVSVAIKRNVVSAWPDASRIGWTIGDGIPYIGSRTE 198

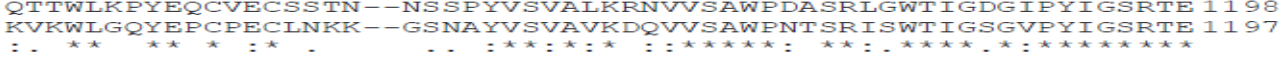

DKIGQPAIKPKCPSAALREAIELASRITWVTQGSSNS DILIKPFLEARVNLSVQEILQMT 1259 DKIGQPAIKPKCPSAAIREA IELTSRITWVTQGGANS DILVKPFIEARVNLSVQEIIQMT 1259

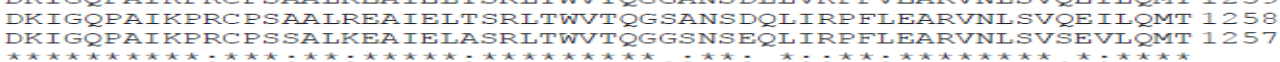


International Journal of Engineering Applied Sciences and Technology, 2020

Vol. 4, Issue 9, ISSN No. 2455-2143, Pages 241-271

Published Online January 2020 in IJEAST (http://www.ijeast.com)

Zaire

Bundibugyo Sudan

Zaire
Tai

Bundibugyo Sudan

Zaire

Bundibugyo Sudan

Zaire

Bundibugyo

Sudan

zaire

Tai

Bundibugyo

Sudan

Zaire
Tai

Bundibugyo

Sudan

Zaire
Tai

Bundibugyo

Sudan

Zaire

Tai

Bundibugyo

Sudan

Reston

Zaire

Tai

Bundibugyo

Sudan

Reston

Zaire

Painaibugyo

Sudan

Zaixe

Bundibugyo

Sudan

Zaixe

Bundibugyo

Sudan
Reston

Zaire
Tailibugyo

Sudan

Zaire
Taildibugyo

Sudan

Zaix

Bundibugyo

Sudan

PSHYSGNIVHRYNDQYSPHSFMANRMSNSATRIIVSTNTLGEFSGGGQSARDSNIIFQNV 1319 PSHYSGNIVHRYNDQYSPHSFMANRMSNSATRIVVSTNTLGEFSGGGQSARDSNIIFRNV 1319 PSHYSGNIVHRYNDQYSPHS FMANRMSNSATRIVVSTNTLGEFSGGGQSARDSNIIFQNV 1319 PSHYSGIVHRYNDQYSPHS MANRMSNTATRLMVSTNTLGEFSGGGQAARDSNIIF RN 1318

INYAVALFDIKFRNTEATDIQYNRAHLHLTKCCTREVPAQYITYTSTLDLDLTRYRENEI 1379 INFAVALFDIRFRNVATSSIQHHRAHLHLSKCCTREVPAQYLVYTSTLPLDITRYRDNEI 1379 INFSVALFDIRFRNTISSIQHNRAHIHLSQCCTREVPAQYITYTSTLSIDITRYRENEI 1379 INFAVALYDIRFRNTCTSSIQYHRAHIHITNCCTREVPAQYLTYTTTLNLDLSKYRNNEI 1378
INLAVALYDIRFRNTNTSDIRHNRAHLHITECCTKEVPAQYITYTSALNLDISRYRDNEI 1377

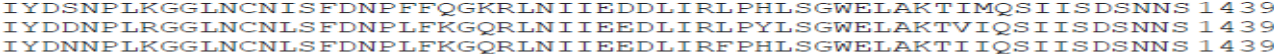
IYDNNPIRGGLNCNLSFDNPIFKGQRINIIEEDIIRFPHLSGWELARTIIQSIISDSNNS 1439 IYDSDPLRGGLNCNISIDSPLMKGPRINIIEDDIIRLPHLSGWELAKTVIQSIISDS SNS 1438
IYDSNPLKGGLNCNLTIDSPIVKGPRINMIEDDILRFPHISGWELAKTVVQSIISDNSNS 1437

STDPISSGETRSFTTHFITYPKIGIIYSFGAFVSYYIGNTIIRTKKITIDNFIYYITTOI 1499 STDPISSGETRSFTTHFITYPKIGLIYSFGAIISYYLGNTIIRTKKLTINNEIYYIATQI 1499 STDPISSGETRSFTTHFLTYPKVGLIYSFGAIVSYYLGNTIIRTKKLDISHFMYYLTTRI 1499

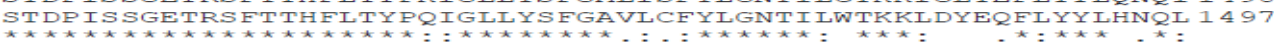

HNLPHRSLRILKPTFKHASVMSRLMSIDPHFSIYIGGAAGDRGLSDAARLFLRTSISSFI 1559 HNLPHRSIRILKPTLKHASVISRIISIDSHFSIYIGGTAGDRGIS DAARIFIRTAITVFI 1559 HNLPHRSIRILKPTFKHVSVISRIMSIDPHFSIYIGGTAGDRGISDATRIFIRVAISSFI 1559 HNLSHRSLRIFKPTFRHSSVMSRIMDIDPNFSIYIGGTAGDRGLSDAARIFIRIAISTFI 1558

TFVKEWIINRGTIVPLWIVYPLEGQNPT PVNNFIYQIVELIVHDSSRQQ--AFKTTISDH 1617 QFVRKWIVERKTAIPLWVIYPLEGQSPSPINSFIHHVIALIQHESSHDH--VCAAEAHSR 1617 QFIKKWIVEYKTAIPLWVIYPLEGQNPDPINSFIHIIIALIQNES PQNN-IIQFQEDRNN 1617 SFVEFWVI FRKANIPLWVIYPLEGQRSDPPGEFINRVKSLIVGTEDDKNKGSIISRSG--1616 *

VHPHDNLVYTCKSTASNFFHASI.AYWRSRHRNSNRKYLARDSSTGSSTNNSD---G---1670 QQLSDNLVYMCKSTASNF FHASLAYWRSRHKGRPKNRSTEEQTVKPI PYDNFHSVRCASN 1677 EKCSSNIVYNCKSTASNF FHASILAYWRGRHRPKKTIGATNATTAPHII----IPLGNSDR 1672

----HIERSQE--------QTTRDPHDGTERNLVLQMSHEI KRTTIPQ---ENTHQGPSF 1715 PESTAVLGSLQ---------TSLAPPPSA-DEATY DRKNKVLKASRPGKYSQNTTKAPPN 1725 PPSIP--KSKS---------GTQGSSAFF-EKLEY DKERELPTASTPAEQSKTYIKALSS 1725 PPGLDLNRNNDTFIPTRIKQIVQGDSRN--DRTTTT-------RFPP--K------SRST 1715 NH-----QSDEKYYN-----VTCGKS PKPQERKDFS-------QYRLSNNGQTMSNHRKK 1716

QSFLSDSACGTANPKLNFDRSRHNVKFQDHNSASKREGHQI ISHRLVLPFFTLSQGTRQL 1775 QT-----SCRDVSPNITG-----TDGCPSANEGSNSNNNNLVSHRIVLPFFTLSHNYNER 1775 RIYHGKTPSNAAKDDSTT-----SKGCDS-----KEENAVQASHRIVLPFFTLSQNDYRT 1775 PTSATEPPTKMYEGSTTHOGKLTD---THLDEDHNAKEFPSNPHRLVVPFFKLTKDGEYS 1772 GKFHKWNPCKMLMESQRGTVLTEG---DYFQNNTPPTDDVSSPHRLILPFFKLGNHNHAH 1773 $\star \star:::^{\star \star \star} \cdot \star \quad:$

TSSNESQTQDEISKYLRQLRSVIDTTVYCRFTGIVSSMHYKLDEVLWEIESFKSAVTLAE 1835

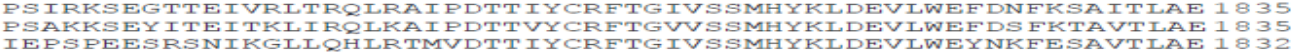

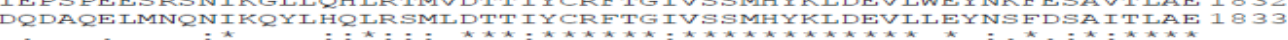

GEGAGALIII KKYOVKTIFFNTLATESSIESEIVSGMTTPRMIIPVMSKFHNDQIEIIIN 1 S 95 GEGSGALIILOKYKVRTIFFNTIATEHSIEAEIVSGTTTPRMIIPVMAKLHDDQINVIIN I 95 GEGSGALIIIQKYGVKKIFINTLATEHSIESEVISGYTTPRMIIPIMPKTHRGEIEVIIN 1892 NSASQITDITNPTWFKDQRARIPKQVEVITMDAETTENINRSKIYEAVYKIIIHHIDPSV 1955 NSASQVTDITNPAWFTDQKSRIPTQVEIMTMDAETTENINRSKIYEAIQQIIVSHIDTRV 1955

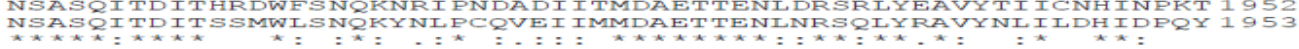
LKAVVLKVELSDTEGMLWLNDNLAPFEATGYLIKPITSSARSSEWYLCITNFISTTRKMP 2015 LKVVVLKVFISDIDGILWINDDNTTPLFGLGYIIKPITSSPKSSEWYICISNILSTSRRIP 2015

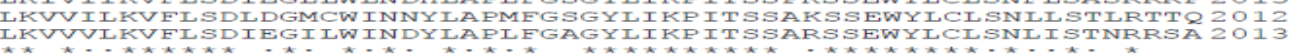
HQNHISCKQVILTAIQLOIQRSPYWLSHITOYADCELHISYIRLGFPSLEKVLYHRYNLV 2075 HQGHATCMQVIQTAIRIQVQRSSYWISHIVQYADINIHISYVNIGEPSIEKVIYHRYNIV 2 O HQTHKACLGVIRDALQAQVQRGVYWLSHIAQYATKNIHCEYIGIGFPSIEKVIYHRYNIV 2073 DSKRGPLVSITQHLAHLRAE IREITNDYNQRRQSRTQTYHFIRTAKGRITKIVNDYLKFF 2135 DSRKGPLVSILYHLTHIQAEIRELVCDYNQQRQSRTOTYHFIKTTKGRITKIVNDYIKFY 2135

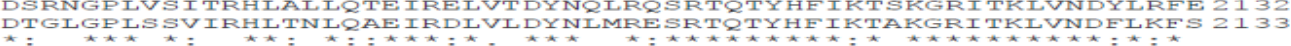


International Journal of Engineering Applied Sciences and Technology, 2020

Vol. 4, Issue 9, ISSN No. 2455-2143, Pages 241-271

Published Online January 2020 in IJEAST (http://www.ijeast.com)

Zaire

Tai

Bundibugyo

Sudan

Reston

zaire

Tai

Bundibugyo

Sudan

Reston
L IVQAL KHNGTWQAEFKKLPELISVCNRFYHIRDCNCEERFLVQTLYL HRMQDSEVKL IE 2195 I I IOAL KHNCTWOEEL RALPDI I SVCTRFYHTRNCSCENRELVOTLYLSRMODSEIKIID 2195 LVVQAL KHNCLWQEELRT LPDL INVCNRFYH IRDCSCEDRFL IQT LYLTRMQDSEAKLME 2195 LVIRAL KNNSTWHHELYLLPEL I GVCHRFNHTRNCTCSERFLVQTLYLHRMSDAE IKLMD 2192 I IVQAL KNNS SWYTELKKLPEVINVCNRFYHTHNCECQEKF FVQTLYLQRLRDAE IKLIE 2193

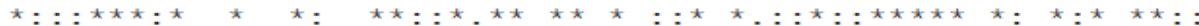

RLTGLLSLFPDGLYRFD-- $\quad 2212$

RLTGLLSLCPNGFFR---- 2210

RLTGFLGLYPNGINA--- - 2210

RLTSLVNMFPEGFRSSSV- 2210

RLTGLMRFYPEGLIYSNHT 2212

$\star \star \star *: * \star * \star *:$

MODULE-3

\section{Nucleoprotein:}

\begin{tabular}{|c|c|c|c|c|c|}
\hline & Tai Forest Ebolavirus & Bundibugyo Ebolavirus & Sudan Ebolavirus & Zaire Ebolavirus & Reston Ebolavirus \\
\hline \multirow[t]{2}{*}{$\begin{array}{l}\text { Gene number;Exon number } \\
\text { and Exon type }\end{array}$} & $\begin{aligned} \text { Gene Number } & =01 \\
\text { Exon Number } & =01 \\
\text { Type of Exon } & =\text { Sngl }\end{aligned}$ & $\begin{array}{l}\text { Gene Number }=01 \\
\text { Exon Number }=01 \\
\text { Type Of Exon }=\text { Sngl }\end{array}$ & $\begin{array}{l}\text { Gene Number }=01 \\
\text { Exon Number }=01 \\
\text { Type of Exon }=\text { Sngl }\end{array}$ & $\begin{array}{l}\text { Gene Number }=01 \\
\text { Exon Number }=01 \\
\text { Type of Exon }=\text { Sngl }\end{array}$ & $\begin{array}{l}\text { Gene Number }=01 \\
\text { Exon Number }=01 \\
\text { Type of Exon }=\text { Sngl }\end{array}$ \\
\hline & $\begin{array}{ll}\text { Gene Number } & =01 \\
\text { Exon Number } & =02 \\
\text { Type of Exon } & =\text { PlyA }\end{array}$ & & $\begin{array}{l}\text { Gene Number }=01 \\
\text { Exon Number }=02 \\
\text { Type Of Exon }=\text { PlyA }\end{array}$ & $\begin{array}{l}\text { Gene Number }=01 \\
\text { Exon Number }=02 \\
\text { Type Of Exon }=\text { PlyA }\end{array}$ & $\begin{array}{l}\text { Gene Number }=01 \\
\text { Exon Number }=02 \\
\text { Type of Exon }=\text { PlyA }\end{array}$ \\
\hline $\begin{array}{l}\text { Type of DNA Strand } \\
+=\text { Input Strand } \\
-=\text { Output Strand }\end{array}$ & $\begin{array}{l}\text { E-1(+=Input strand) } \\
\text { E-2(+=Input Strand) }\end{array}$ & E-1(+= Input Strand) & $\begin{array}{l}\text { E-1(+=Input Strand) } \\
\text { E-2(+=Input Strand) }\end{array}$ & $\begin{array}{l}\text { E-1(+=Input Strand) } \\
\text { E-2(+=Input strand) }\end{array}$ & $\begin{array}{l}\text { E-1(+=Input Strand) } \\
\text { E-2(+=Input Strand) }\end{array}$ \\
\hline Beginning of Exon/Signal & $\begin{array}{l}E-1=409 \\
E-2=2677\end{array}$ & $E-1=403$ & $\begin{array}{l}\mathrm{E}-1=403 \\
\mathrm{E}-2=2734\end{array}$ & $\begin{array}{l}\mathrm{E}-1=415 \\
\mathrm{E}-2=2743\end{array}$ & $\begin{array}{l}\mathrm{E}-1=409 \\
\mathrm{E}-2=2947\end{array}$ \\
\hline Ending of Exon/signal & $\begin{array}{l}E-1=2628 \\
E-2=2682\end{array}$ & $E-1=2622$ & $\begin{array}{l}E-1=2619 \\
E-2=2739\end{array}$ & $\begin{array}{l}E-1=2634 \\
E-2=2748\end{array}$ & $\begin{array}{l}\mathrm{E}-1=2628 \\
\mathrm{E}-2=2952\end{array}$ \\
\hline Length of Exon/signal & $\begin{array}{l}E-1=2220 \\
E-2=06\end{array}$ & $E-1=2220$ & $\begin{array}{l}\mathrm{E}-1=2217 \\
\mathrm{E}-2=06\end{array}$ & $\begin{array}{l}\mathrm{E}-1=2220 \\
\mathrm{E}-2=06\end{array}$ & $\begin{array}{l}\mathrm{E}-1=2220 \\
\mathrm{E}-2=06\end{array}$ \\
\hline Reading Frame & $\begin{array}{l}\mathrm{E}-1=0 \\
\mathrm{E}-2=()\end{array}$ & $E-1=0$ & $\begin{array}{l}E-1=0 \\
E-2=()\end{array}$ & $\begin{array}{l}\mathrm{E}-1=0 \\
\mathrm{E}-2=()\end{array}$ & $\begin{array}{l}\mathrm{E}-1=0 \\
\mathrm{E}-2=()\end{array}$ \\
\hline Net-Phase of Exon/Signal & $\begin{array}{l}E-1=0 \\
E-2=()\end{array}$ & $E-1=0$ & $\begin{array}{l}\mathrm{E}-1=0 \\
\mathrm{E}-2=()\end{array}$ & $\begin{array}{l}E-1=0 \\
E-2=()\end{array}$ & $\begin{array}{l}\mathrm{E}-1=0 \\
\mathrm{E}-2=()\end{array}$ \\
\hline $\begin{array}{l}\text { Initiation signal/3'-Splice } \\
\text { site score }\end{array}$ & $\begin{array}{l}E-1=99 \\
E-2=()\end{array}$ & $E-1=75$ & $\begin{array}{l}\mathrm{E}-1=81 \\
\mathrm{E}-2=(\mathrm{)}\end{array}$ & $\begin{array}{l}E-1=55 \\
E-2=()\end{array}$ & $\begin{array}{l}E-1=71 \\
E-2=()\end{array}$ \\
\hline $\begin{array}{l}\text { Termination signal/5'-Splice } \\
\text { site score }\end{array}$ & $\begin{array}{l}\mathrm{E}-1=28 \\
\mathrm{E}-2=()\end{array}$ & $E-1=42$ & $\begin{array}{l}\mathrm{E}-1=55 \\
\mathrm{E}-2=()\end{array}$ & $\begin{array}{l}E-1=42 \\
E-2=()\end{array}$ & $\begin{array}{l}\mathrm{E}-1=41 \\
\mathrm{E}-2=(\mathrm{)}\end{array}$ \\
\hline Coding Region score & $\begin{array}{l}\mathrm{E}-1=1622 \\
\mathrm{E}-2=()\end{array}$ & $E-1=1481$ & $\begin{array}{l}\mathrm{E}-1=1662 \\
\mathrm{E}-2=()\end{array}$ & $\begin{array}{l}\mathrm{E}-1=1366 \\
\mathrm{E}-2=(\mathrm{)}\end{array}$ & $\begin{array}{l}\mathrm{E}-1=1420 \\
\mathrm{E}-2=()\end{array}$ \\
\hline Probability of Exon & $\begin{array}{l}\mathrm{E}-1=0.776 \\
\mathrm{E}-2=()\end{array}$ & $E-1=0.478$ & $\begin{array}{l}\mathrm{E}-1=0.998 \\
\mathrm{E}-2=()\end{array}$ & $\begin{array}{l}\mathrm{E}-1=0.578 \\
\mathrm{E}-2=()\end{array}$ & $\begin{array}{l}\mathrm{E}-1=0.921 \\
\mathrm{E}-2=()\end{array}$ \\
\hline Exon score & $\begin{array}{l}\mathrm{E}-1=151.05 \\
\mathrm{E}-2=-3.64\end{array}$ & $E-1=135.75$ & $\begin{array}{l}\mathrm{E}-1=155.98 \\
\mathrm{E}-2=1.05\end{array}$ & $\begin{array}{l}\mathrm{E}-1=122.45 \\
\mathrm{E}-2=1.05\end{array}$ & $\begin{array}{l}\mathrm{E}-1=129.35 \\
\mathrm{E}-2=-1.75\end{array}$ \\
\hline
\end{tabular}

\section{Polvmerase complex protein}

\begin{tabular}{|c|c|c|c|c|c|}
\hline & Tai Forest Ebolavirus & Bundibugyo Ebolavirus & Sudan Ebolavirus & Zaire Ebolavirus & Reston Ebolavirus \\
\hline \multirow[t]{2}{*}{$\begin{array}{l}\text { Gene number;Exon number } \\
\text { and Exon type }\end{array}$} & $\begin{array}{l}\text { Gene number }=01 \\
\text { Exon Number }=01 \\
\text { Type of Exon }=\text { Init }\end{array}$ & $\begin{array}{l}\text { Gene number }=01 \\
\text { Exon number }=01 \\
\text { Type of Exon }=\text { Sngl }\end{array}$ & $\begin{array}{l}\text { Gene number }=01 \\
\text { Exon number }=01 \\
\text { Type of Exon }=\text { Sng1 }\end{array}$ & $\begin{array}{l}\text { Gene number }=01 \\
\text { Exon number }=01 \\
\text { Type of Exon }=\text { Sng1 }\end{array}$ & $\begin{array}{l}\text { Gene number }=01 \\
\text { Exon number }=01 \\
\text { Type of Exon }=\text { Sngl }\end{array}$ \\
\hline & & $\begin{array}{l}\text { Gene number }=01 \\
\text { Exon number }=02 \\
\text { Type of Exon }=\text { PlyA }\end{array}$ & $\begin{array}{l}\text { Gene number }=01 \\
\text { Exon number }=02 \\
\text { Type of Exon }=\text { PlyA }\end{array}$ & $\begin{array}{l}\text { Gene number }=01 \\
\text { Exon number }=02 \\
\text { Type of Exon }=\text { PlyA }\end{array}$ & $\begin{array}{l}\text { Gene number }=01 \\
\text { Exon number }=02 \\
\text { Type of Exon }=\text { PlyA }\end{array}$ \\
\hline $\begin{array}{l}\text { Type of DNA Strand } \\
+=\text { Input Strand } \\
-=\text { Output Strand }\end{array}$ & E-1(+=Input Strand) & $\begin{array}{l}\text { E-1(+= Input strand) } \\
\text { E-2(+=Input Strand) }\end{array}$ & $\begin{array}{l}\text { E-1(+=Input strand) } \\
\text { E-2(+=Input Strand) }\end{array}$ & $\begin{array}{l}\text { E-1(+=Input strand) } \\
\text { E-2(+=Input strand })\end{array}$ & $\begin{array}{l}\text { E-1(+=Input strand) } \\
\text { E-2(+=Input strand })\end{array}$ \\
\hline Beginning of Exon/Signal & $\mathrm{E}-1=89$ & $\begin{array}{l}\text { E-1 }=89 \\
\text { E-2 }=1303\end{array}$ & $\begin{array}{l}\mathrm{E}-1=126 \\
\mathrm{E}-2=1343\end{array}$ & $\begin{array}{l}\mathrm{E}-1=98 \\
\mathrm{E}-2=1238\end{array}$ & $\begin{array}{l}\mathrm{E}-1=137 \\
\mathrm{E}-2=1218\end{array}$ \\
\hline Ending of Exon/signal & $\mathrm{E}-1=1004$ & $\begin{array}{l}\mathrm{E}-1=1114 \\
\mathrm{E}-2=1308\end{array}$ & $\begin{array}{l}\mathrm{E}-1=1115 \\
\mathrm{E}-2=1348\end{array}$ & $\begin{array}{l}\mathrm{E}-1=1120 \\
\mathrm{E}-2=1243\end{array}$ & $\begin{array}{l}\mathrm{E}-1=1126 \\
\mathrm{E}-2=1223\end{array}$ \\
\hline Length of Exon/signal & $\mathrm{E}-1=916$ & $\begin{array}{l}\mathrm{E}-1=1026 \\
\mathrm{E}-2=06\end{array}$ & $\begin{aligned} \text { E-1 } & =990 \\
\text { E-2 } & =06\end{aligned}$ & $\begin{array}{l}\mathrm{E}-1=1023 \\
\mathrm{E}-2=06\end{array}$ & $\begin{array}{l}\mathrm{E}-1=990 \\
\mathrm{E}-2=06\end{array}$ \\
\hline Reading Frame & $\mathrm{E}-1=01$ & $\begin{array}{l}\mathrm{E}-1=01 \\
\mathrm{E}-2=()\end{array}$ & $\begin{array}{l}\mathrm{E}-1=02 \\
\mathrm{E}-2=()\end{array}$ & $\begin{array}{l}\mathrm{E}-1=01 \\
\mathrm{E}-2=()\end{array}$ & $\begin{array}{l}\mathrm{E}-1=01 \\
\mathrm{E}-2=()\end{array}$ \\
\hline Net-Phase of Exon/Signal & $\mathrm{E}-1=01$ & $\begin{array}{l}\mathrm{E}-1=00 \\
\mathrm{E}-2=(\mathrm{)}\end{array}$ & $\begin{array}{l}E-1=00 \\
E-2=()\end{array}$ & $\begin{array}{l}\mathrm{E}-1=00 \\
\mathrm{E}-2=()\end{array}$ & $\begin{array}{l}\mathrm{E}-1=00 \\
\mathrm{E}-2=(\mathrm{)}\end{array}$ \\
\hline
\end{tabular}


International Journal of Engineering Applied Sciences and Technology, 2020

Vol. 4, Issue 9, ISSN No. 2455-2143, Pages 241-271

Published Online January 2020 in IJEAST (http://www.ijeast.com)

\begin{tabular}{|c|c|c|c|c|c|}
\hline $\begin{array}{l}\text { Initiation signal/3'-Splice } \\
\text { site score }\end{array}$ & $\mathrm{E}-1=42$ & $\begin{array}{l}E-1=75 \\
E-2=()\end{array}$ & $\begin{array}{l}\text { E-1 }=71 \\
\text { E-2 }=()\end{array}$ & $\begin{array}{l}\mathrm{E}-1=66 \\
\mathrm{E}-2=()\end{array}$ & $\begin{array}{l}\mathrm{E}-1=69 \\
\mathrm{E}-2=()\end{array}$ \\
\hline $\begin{array}{l}\text { Termination signal/5' -Splice } \\
\text { site score }\end{array}$ & $E-1=3$ & $\begin{array}{l}E-1=45 \\
E-2=()\end{array}$ & $\begin{array}{l}\mathrm{E}-1=43 \\
\mathrm{E}-2=()\end{array}$ & $\begin{array}{l}E-1=52 \\
E-2=()\end{array}$ & $\begin{array}{l}E-1=48 \\
E-2=()\end{array}$ \\
\hline Coding Region score & $E-1=568$ & $\begin{array}{l}E-1=296 \\
E-2=()\end{array}$ & $\begin{array}{l}\text { E-1 }=819 \\
\text { E-2 }=()\end{array}$ & $\begin{array}{l}\text { E-1 }=843 \\
\text { E-2 }=()\end{array}$ & $\begin{array}{l}\text { E-1 }=813 \\
E-2=()\end{array}$ \\
\hline Probability of Exon & $\mathrm{E}-1=0.455$ & $\begin{array}{l}\mathrm{E}-1=0.283 \\
\mathrm{E}-2=()\end{array}$ & $\begin{array}{l}\mathrm{E}-1=0.534 \\
\mathrm{E}-2=()\end{array}$ & $\begin{array}{l}\mathrm{E}-1=0.847 \\
\mathrm{E}-2=()\end{array}$ & $\begin{array}{l}\mathrm{E}-1=0.846 \\
\mathrm{E}-1=()\end{array}$ \\
\hline Exon score & $E-1=37.93$ & $\begin{array}{l}\mathrm{E}-1=21.09 \\
\mathrm{E}-2=1.05\end{array}$ & $\begin{array}{l}\text { E-1 }=72.31 \\
\text { E-2 }=-1.75\end{array}$ & $\begin{array}{l}\text { E-1 }=75.31 \\
\text { E-2 }=-1.75\end{array}$ & $\begin{array}{l}\text { E-1 }=72.01 \\
\text { E-2 }=-1.75\end{array}$ \\
\hline
\end{tabular}

\section{Matrix Protein:}

\begin{tabular}{|c|c|c|c|c|c|}
\hline & Tai Forest Ebolavirus & Bundibugyo Ebolavirus & Sudan Ebolavirus & Zaire Ebolavirus & Reston Ebolavirus \\
\hline \multirow[t]{2}{*}{$\begin{array}{l}\text { Gene number;Exon number } \\
\text { and Exon type }\end{array}$} & $\begin{array}{l}\text { Gene number }=01 \\
\text { Exon number }=01 \\
\text { Type of Exon }=\text { Init }\end{array}$ & $\begin{array}{l}\text { Gene number }=01 \\
\text { Exon number }=01 \\
\text { Type of Exon }=\text { Init }\end{array}$ & $\begin{array}{l}\text { Gene number }=01 \\
\text { Exon number }=01 \\
\text { Type of Exon }=\text { Sngl }\end{array}$ & $\begin{array}{l}\text { Gene number }=01 \\
\text { Exon number }=01 \\
\text { Type of Exon }=\text { Sngl }\end{array}$ & $\begin{array}{l}\text { Gene number }=01 \\
\text { Exon number }=01 \\
\text { Type of Exon }=\text { Sngl }\end{array}$ \\
\hline & $\begin{array}{l}\text { Gene number }=01 \\
\text { Exon number }=02 \\
\text { Type of Exon }=\text { Term }\end{array}$ & $\begin{array}{l}\text { Gene number }=01 \\
\text { Exon number }=02 \\
\text { Type of Exon }=\text { Intr }\end{array}$ & $\begin{array}{l}\text { Gene number }=01 \\
\text { Exon number }=02 \\
\text { Type of Exon }=\text { PlyA }\end{array}$ & $\begin{array}{l}\text { Gene number }=01 \\
\text { Exon number }=02 \\
\text { Type of Exon }=\text { PlyA }\end{array}$ & $\begin{array}{l}\text { Gene number }=01 \\
\text { Exon number }=02 \\
\text { Type of Exon }=\text { PlyA }\end{array}$ \\
\hline $\begin{array}{l}\text { Type of DNA Strand } \\
+=\text { Input Strand } \\
-=\text { Output Strand }\end{array}$ & $\begin{array}{l}\text { E-1(+= Input strand) } \\
\text { E-2(+= Input strand })\end{array}$ & $\begin{array}{l}\text { E-1(+= Input strand) } \\
\text { E-2(+= Input strand })\end{array}$ & $\begin{array}{l}\text { E-1(+= Input strand) } \\
\text { E-2(+= Input strand })\end{array}$ & $\begin{array}{l}\text { E-1(+= Input strand) } \\
\text { E-2(+= Input strand) }\end{array}$ & $\begin{array}{l}\text { E-1(+= Input Strand }) \\
\text { E-2(+ = Input Strand })\end{array}$ \\
\hline Beginning of Exon/Signal & $\begin{array}{l}\mathrm{E}-1=90 \\
\mathrm{E}-2=1098\end{array}$ & $\begin{array}{l}\mathrm{E}-1=90 \\
\mathrm{E}-2=1046\end{array}$ & $\begin{array}{l}\text { E-1 }=90 \\
\text { E-2 }=1293\end{array}$ & $\begin{array}{l}\mathrm{E}-1=90 \\
\mathrm{E}-2=1435\end{array}$ & $\begin{array}{l}\text { E-1 }=90 \\
\text { E-2 }=1274\end{array}$ \\
\hline Ending of Exon/signal & $\begin{array}{l}\mathrm{E}-1=990 \\
\mathrm{E}-2=1498\end{array}$ & $\begin{array}{l}\mathrm{E}-1=1004 \\
\mathrm{E}-1=1225\end{array}$ & $\begin{array}{l}\text { E-1 }=1070 \\
\text { E-2 }=1298\end{array}$ & $\begin{array}{l}\text { E-1 }=1070 \\
\text { E-2 }=1440\end{array}$ & $\begin{array}{l}\mathrm{E}-1=1085 \\
\text { E-2 }=1279\end{array}$ \\
\hline Length of Exon/signal & $\begin{array}{l}E-1=901 \\
E-2=401\end{array}$ & $\begin{array}{l}E-1=915 \\
E-2=180\end{array}$ & $\begin{array}{l}\text { E-1 }=981 \\
\text { E-2 }=06\end{array}$ & $\begin{array}{l}E-1=981 \\
E-2=06\end{array}$ & $\begin{array}{l}E-1=996 \\
E-2=06\end{array}$ \\
\hline Reading Frame & $\begin{array}{l}E-1=02 \\
E-2=01\end{array}$ & $\begin{array}{l}E-1=02 \\
E-2=01\end{array}$ & $\begin{array}{l}\mathrm{E}-1=02 \\
\mathrm{E}-2=()\end{array}$ & $\begin{array}{l}E-1=02 \\
E-2=()\end{array}$ & $\begin{array}{l}E-1=02 \\
E-2=()\end{array}$ \\
\hline Net-Phase of Exon/Signal & $\begin{array}{l}E-1=01 \\
E-2=02\end{array}$ & $\begin{array}{l}E-1=00 \\
E-2=00\end{array}$ & $\begin{array}{l}\text { E-1 }=00 \\
E-2=()\end{array}$ & $\begin{array}{l}E-1=00 \\
E-2=()\end{array}$ & $\begin{array}{l}E-1=00 \\
E-2=()\end{array}$ \\
\hline $\begin{array}{l}\text { Initiation signal/3'-Splice } \\
\text { site score }\end{array}$ & $\begin{array}{l}E-1=81 \\
E-2=20\end{array}$ & $\begin{array}{l}\mathrm{E}-1=101 \\
\mathrm{E}-2=72\end{array}$ & $\begin{array}{l}\mathrm{E}-1=64 \\
\mathrm{E}-2=()\end{array}$ & $\begin{array}{l}E-1=48 \\
E-2=()\end{array}$ & $\begin{array}{l}E-1=60 \\
E-2=()\end{array}$ \\
\hline $\begin{array}{l}\text { Termination signal/5'-Splice } \\
\text { site score }\end{array}$ & $\begin{array}{l}E-1=53 \\
E-2=48\end{array}$ & $\begin{array}{l}E-1=-6 \\
E-2=69\end{array}$ & $\begin{array}{l}\text { E-1 }=37 \\
E-2=()\end{array}$ & $\begin{array}{l}E-1=32 \\
E-2=()\end{array}$ & $\begin{array}{l}E-1=28 \\
E-2=()\end{array}$ \\
\hline Coding Region score & $\begin{array}{l}\text { E-1 }=349 \\
\text { E-2 }=287\end{array}$ & $\begin{array}{l}\mathrm{E}-1=427 \\
\mathrm{E}-2=239\end{array}$ & $\begin{array}{l}\text { E-1 }=279 \\
\text { E-2 }=()\end{array}$ & $\begin{array}{l}\mathrm{E}-1=837 \\
\mathrm{E}-2=()\end{array}$ & $\begin{array}{l}E-1=692 \\
E-2=()\end{array}$ \\
\hline Probability of Exon & $\begin{array}{l}\mathrm{E}-1=0.752 \\
\mathrm{E}-2=0.989\end{array}$ & $\begin{array}{l}\mathrm{E}-1=0.769 \\
\mathrm{E}-2=0.823\end{array}$ & $\begin{array}{l}\mathrm{E}-1=0.632 \\
\mathrm{E}-2=()\end{array}$ & $\begin{array}{l}\mathrm{E}-1=0.840 \\
\mathrm{E}-2=()\end{array}$ & $\begin{array}{l}\mathrm{E}-1=0.728 \\
\mathrm{E}-2=()\end{array}$ \\
\hline Exon score & $\begin{array}{l}\mathrm{E}-1=25.13 \\
\mathrm{E}-2=13.18\end{array}$ & $\begin{array}{l}\mathrm{E}-1=28.67 \\
\mathrm{E}-2=20.46\end{array}$ & $\begin{array}{l}\text { E-1 }=17.22 \\
\text { E-2 }=-1.75\end{array}$ & $\begin{array}{l}\text { E-1 }=70.65 \\
\text { E-2 }=-0.45\end{array}$ & $\begin{array}{l}E-1=57.05 \\
E-2=-1.75\end{array}$ \\
\hline
\end{tabular}

\section{Small Secreted Glvcoprotein:}

\begin{tabular}{|l|l|l|l|l|l|}
\hline & Tai Forest Ebolavirus & Bundibugyo Ebolavirus & Sudan Ebolavirus & Zaire Ebolavirus & Reston Ebolavirus \\
\hline $\begin{array}{l}\text { Gene number; Exon number } \\
\text { and Exon type }\end{array}$ & $\begin{array}{l}\text { Gene number }=01 \\
\text { Exon number }=01 \\
\text { Type of Exon= Init }\end{array}$ & $\begin{array}{l}\text { Gene number }=01 \\
\text { Exon number }=01 \\
\text { Type of Exon }=\text { Init }\end{array}$ & $\begin{array}{l}\text { Gene number }=01 \\
\text { Exon number }=01 \\
\text { Type of Exon }=\text { Init }\end{array}$ & $\begin{array}{l}\text { Gene number }=01 \\
\text { Exon number }=01 \\
\text { Type of Exon }=\text { Intr }\end{array}$ & $\begin{array}{l}\text { Eene number }=01 \\
\text { Type of Exon }=\text { Init }\end{array}$ \\
\cline { 2 - 6 } & Gene number $=01$ & Gene number $=01$ & Gene number $=01$ & Gene number $=01$ & Gene number $=01$ \\
\hline
\end{tabular}


International Journal of Engineering Applied Sciences and Technology, 2020

Vol. 4, Issue 9, ISSN No. 2455-2143, Pages 241-271

Published Online January 2020 in IJEAST (http://www.ijeast.com)

\begin{tabular}{|c|c|c|c|c|c|}
\hline & $\begin{array}{l}\text { Exon number }=02 \\
\text { Type of Exon }=\text { Term }\end{array}$ & $\begin{array}{l}\text { Exon number }=02 \\
\text { Type of Exon }=\text { Term }\end{array}$ & $\begin{array}{l}\text { Exon number }=02 \\
\text { Type of Exon }=\text { Term }\end{array}$ & $\begin{array}{l}\text { Exon number }=02 \\
\text { Type of Exon }=\text { Intr }\end{array}$ & $\begin{array}{l}\text { Exon number }=02 \\
\text { Type of Exon }=\text { Intr }\end{array}$ \\
\hline & $\begin{array}{l}\text { Gene number }=01 \\
\text { Exon number }=03 \\
\text { Type of Exon }=\text { PlyA }\end{array}$ & $\begin{array}{l}\text { Gene number }=01 \\
\text { Exon number }=03 \\
\text { Type of Exon }=\text { PlyA }\end{array}$ & & & \\
\hline $\begin{array}{l}\text { Type of DNA Strand } \\
+=\text { Input Strand } \\
-=\text { Output Strand }\end{array}$ & $\begin{array}{l}\text { E-1(+= Input strand) } \\
\text { E-2(+= Input strand) } \\
\text { E-3(+= Input strand) }\end{array}$ & $\begin{array}{l}\text { E-1(+= Input Strand) } \\
\text { E-2(+= Input Strand) } \\
\text { E-3(+= Input Strand) }\end{array}$ & $\begin{array}{l}\text { E-1(+ = Input Strand) } \\
\text { E-2(+ = Input Strand })\end{array}$ & $\begin{array}{l}\text { E-1(+ = Input Strand) } \\
\text { E-2(+ = Input Strand) }\end{array}$ & $\begin{array}{l}\text { E-1(+= Input strand) } \\
\text { E-2(+ = Input Strand })\end{array}$ \\
\hline Beginning of Exon/Signal & $\begin{array}{l}\mathrm{E}-1=140 \\
\mathrm{E}-2=1076 \\
\mathrm{E}-3=2356\end{array}$ & $\begin{array}{l}\text { E-1 }=140 \\
\text { E-2 }=1052 \\
\text { E-3 }=2373\end{array}$ & $\begin{array}{l}\mathrm{E}-1=116 \\
\mathrm{E}-2=1043\end{array}$ & $\begin{array}{l}\mathrm{E}-1=425 \\
\mathrm{E}-2=1035\end{array}$ & $\begin{array}{l}\mathrm{E}-1=142 \\
\mathrm{E}-2=1102\end{array}$ \\
\hline Ending of Exon/signal & $\begin{array}{l}\mathrm{E}-1=995 \\
\mathrm{E}-2=2169 \\
\mathrm{E}-3=2361\end{array}$ & $\begin{array}{l}\mathrm{E}-1=995 \\
\mathrm{E}-2=2169 \\
\mathrm{E}-3=2378\end{array}$ & $\begin{array}{l}\text { E-1 }=971 \\
\text { E-2 }=2145\end{array}$ & $\begin{array}{l}\text { E-1 }=999 \\
\text { E-2 }=2101\end{array}$ & $\begin{array}{l}\mathrm{E}-1=1000 \\
\mathrm{E}-2=1938\end{array}$ \\
\hline Length of Exon/signal & $\begin{array}{l}\mathrm{E}-1=856 \\
\mathrm{E}-2=1094 \\
\mathrm{E}-3=06\end{array}$ & $\begin{array}{l}\mathrm{E}-1=856 \\
\mathrm{E}-2=1118 \\
\mathrm{E}-3=06\end{array}$ & $\begin{array}{l}\mathrm{E}-1=856 \\
\mathrm{E}-2=1103\end{array}$ & $\begin{array}{l}\mathrm{E}-1=575 \\
\mathrm{E}-2=1067\end{array}$ & $\begin{array}{l}\text { E-1 }=859 \\
\text { E-2 }=837\end{array}$ \\
\hline Reading Frame & $\begin{array}{l}\mathrm{E}-1=01 \\
\mathrm{E}-2=00 \\
\mathrm{E}-3=()\end{array}$ & $\begin{array}{l}E-1=01 \\
E-2=00 \\
E-3=()\end{array}$ & $\begin{array}{l}\mathrm{E}-1=01 \\
\mathrm{E}-2=00\end{array}$ & $\begin{array}{l}\mathrm{E}-1=01 \\
\mathrm{E}-2=00\end{array}$ & $\begin{array}{l}\mathrm{E}-1=00 \\
\mathrm{E}-2=02\end{array}$ \\
\hline Net-Phase of Exon/Signal & $\begin{array}{l}\mathrm{E}-1=01 \\
\mathrm{E}-2=02 \\
\mathrm{E}-3=()\end{array}$ & $\begin{array}{l}\mathrm{E}-1=01 \\
\mathrm{E}-2=02 \\
\mathrm{E}-3=()\end{array}$ & $\begin{array}{l}\mathrm{E}-1=01 \\
\mathrm{E}-2=02\end{array}$ & $\begin{array}{l}\mathrm{E}-1=02 \\
\mathrm{E}-2=02\end{array}$ & $\begin{array}{l}\mathrm{E}-1=01 \\
\mathrm{E}-2=00\end{array}$ \\
\hline $\begin{array}{l}\text { Initiation signal/3'-Splice } \\
\text { site score }\end{array}$ & $\begin{array}{l}\mathrm{E}-1=84 \\
\mathrm{E}-2=35 \\
\mathrm{E}-3=()\end{array}$ & $\begin{array}{l}E-1=87 \\
E-2=-37 \\
E-3=()\end{array}$ & $\begin{array}{l}E-1=82 \\
E-2=-50\end{array}$ & $\begin{array}{l}E-1=39 \\
E-2=-12\end{array}$ & $\begin{array}{l}\text { E-1 }=87 \\
\text { E-2 }=34\end{array}$ \\
\hline $\begin{array}{l}\text { Termination signal/5'-Splice } \\
\text { site score }\end{array}$ & $\begin{array}{l}\mathrm{E}-1=92 \\
\mathrm{E}-2=43 \\
\mathrm{E}-3=()\end{array}$ & $\begin{array}{l}\mathrm{E}-1=36 \\
\mathrm{E}-2=33 \\
\mathrm{E}-3=()\end{array}$ & $\begin{array}{l}\text { E-1 }=-4 \\
\text { E-2 }=42\end{array}$ & $\begin{array}{l}E-1=-12 \\
E-2=72\end{array}$ & $\begin{array}{l}\mathrm{E}-1=97 \\
\mathrm{E}-2=67\end{array}$ \\
\hline Coding Region score & $\begin{array}{l}\mathrm{E}-1=285 \\
\mathrm{E}-2=497 \\
\mathrm{E}-3=()\end{array}$ & $\begin{array}{l}\mathrm{E}-1=496 \\
\mathrm{E}-2=430 \\
\mathrm{E}-3=()\end{array}$ & $\begin{array}{l}\mathrm{E}-1=305 \\
\mathrm{E}-2=578\end{array}$ & $\begin{array}{l}\mathrm{E}-1=423 \\
\mathrm{E}-2=611\end{array}$ & $\begin{array}{l}\mathrm{E}-1=415 \\
\mathrm{E}-2=425\end{array}$ \\
\hline Probability of Exon & $\begin{array}{l}\mathrm{E}-1=0.896 \\
\mathrm{E}-2=0.979 \\
\mathrm{E}-3=()\end{array}$ & $\begin{array}{l}\mathrm{E}-1=0.908 \\
\mathrm{E}-2=0.134 \\
\mathrm{E}-3=()\end{array}$ & $\begin{array}{l}\mathrm{E}-1=0.237 \\
\mathrm{E}-2=0.309\end{array}$ & $\begin{array}{l}\mathrm{E}-1=0.365 \\
\mathrm{E}-2=0.734\end{array}$ & $\begin{array}{l}\mathrm{E}-1=0.835 \\
\mathrm{E}-2=0.362\end{array}$ \\
\hline Exon score & $\begin{array}{l}\mathrm{E}-1=23.30 \\
\mathrm{E}-2=32.16 \\
\mathrm{E}-3=1.05\end{array}$ & $\begin{array}{l}\mathrm{E}-1=39.10 \\
\mathrm{E}-2=17.20 \\
\mathrm{E}-3=1.05\end{array}$ & $\begin{array}{l}\mathrm{E}-1=15.51 \\
\mathrm{E}-2=31.64\end{array}$ & $\begin{array}{l}\mathrm{E}-1=18.94 \\
\mathrm{E}-2=39.43\end{array}$ & $\begin{array}{l}E-1=37.09 \\
E-2=26.36\end{array}$ \\
\hline
\end{tabular}

Second Secreted Glycoprotein:

\begin{tabular}{|c|c|c|c|c|c|}
\hline & Tai Forest Ebolavirus & Bundibugyo Ebolavirus & Sudan Ebolavirus & Zaire Ebolavirus & Reston Ebolavirus \\
\hline \multirow[t]{3}{*}{$\begin{array}{l}\text { Gene number;Exon number } \\
\text { and Exon type }\end{array}$} & $\begin{array}{l}\text { Gene number }=01 \\
\text { Exon number }=01 \\
\text { Type of Exon }=\text { init }\end{array}$ & $\begin{array}{l}\text { Gene number }=01 \\
\text { Exon number }=01 \\
\text { Type of Exon }=\text { Init }\end{array}$ & $\begin{array}{l}\text { Gene number }=01 \\
\text { Exon number }=01 \\
\text { Type of Exon }=\text { Init }\end{array}$ & $\begin{array}{l}\text { Gene number }=01 \\
\text { Exon number }=01 \\
\text { Type of Exon }=\text { Intr }\end{array}$ & $\begin{array}{l}\text { Gene number }=01 \\
\text { Exon number }=01 \\
\text { Type of Exon }=\text { Init }\end{array}$ \\
\hline & $\begin{array}{l}\text { Gene number }=01 \\
\text { Exon number }=02 \\
\text { Type of Exon }=\text { Term }\end{array}$ & $\begin{array}{l}\text { Gene number }=01 \\
\text { Exon number }=02 \\
\text { Type of Exon }=\text { Term }\end{array}$ & $\begin{array}{l}\text { Gene number }=01 \\
\text { Exon number }=02 \\
\text { Type of exon }=\text { Term }\end{array}$ & $\begin{array}{l}\text { Gene number }=01 \\
\text { Exon number }=02 \\
\text { Type of exon }=\text { Intr }\end{array}$ & $\begin{array}{l}\text { Gene number }=01 \\
\text { Exon number }=02 \\
\text { Type of exon }=\text { Intr }\end{array}$ \\
\hline & $\begin{array}{l}\text { Gene number }=01 \\
\text { Exon number }=03 \\
\text { Type of Exon }=\text { PlyA }\end{array}$ & $\begin{array}{l}\text { Gene number }=01 \\
\text { Exon number }=03 \\
\text { Type of Exon }=\text { PlyA }\end{array}$ & & & \\
\hline $\begin{array}{l}\text { Type of DNA Strand } \\
\text { += Input Strand } \\
\text { - = Output Strand }\end{array}$ & $\begin{array}{l}\text { E-1(+= Input Strand) } \\
\text { E-2(+= Input strand) } \\
\text { E-3(+= Input strand) }\end{array}$ & $\begin{array}{l}\text { E-1(+= Input Strand) } \\
\text { E-2(+= Input Strand) } \\
\text { E-3(+= Input Strand })\end{array}$ & $\begin{array}{l}\text { E-1(+= Input Strand }) \\
\text { E-2(+= Input Strand })\end{array}$ & $\begin{array}{l}\text { E-1(+= Input strand) } \\
\text { E-2(+= Input Strand) }\end{array}$ & $\begin{array}{l}\text { E-1(+= Input strand) } \\
\text { E-2(+= Input strand })\end{array}$ \\
\hline Beginning of Exon/Signal & $\begin{array}{l}E-1=140 \\
E-2=1076 \\
E-3=2356\end{array}$ & $\begin{array}{l}E-1=140 \\
E-2=1052 \\
E-3=2373\end{array}$ & $\begin{array}{l}E-1=116 \\
E-2=1043\end{array}$ & $\begin{array}{l}E-1=425 \\
E-2=1035\end{array}$ & $\begin{array}{l}E-1=142 \\
E-2=1102\end{array}$ \\
\hline Ending of Exon/signal & $\begin{array}{l}E-1=995 \\
E-2=2169 \\
E-3=2361\end{array}$ & $\begin{array}{l}E-1=995 \\
E-2=2169 \\
E-3=2378\end{array}$ & $\begin{array}{l}\text { E-1 }=971 \\
\text { E-2 }=2145\end{array}$ & $\begin{array}{l}E-1=999 \\
E-2=2101\end{array}$ & $\begin{array}{l}E-1=1000 \\
E-2=1938\end{array}$ \\
\hline Length of Exon/signal & $\begin{array}{l}E-1=856 \\
E-2=1094 \\
E-3=06\end{array}$ & $\begin{array}{l}E-1=856 \\
E-2=1118 \\
E-3=06\end{array}$ & $\begin{array}{l}E-1=856 \\
E-2=1103\end{array}$ & $\begin{array}{l}E-1=575 \\
E-2=1067\end{array}$ & $\begin{array}{l}E-1=859 \\
E-2=837\end{array}$ \\
\hline Reading Frame & $\begin{array}{l}E-1=01 \\
E-2=00 \\
E-3=()\end{array}$ & $\begin{array}{l}E-1=01 \\
E-2=00 \\
E-3=()\end{array}$ & $\begin{array}{l}E-1=01 \\
E-2=00\end{array}$ & $\begin{array}{l}E-1=01 \\
E-1=00\end{array}$ & $\begin{array}{l}\mathrm{E}-1=00 \\
\mathrm{E}-2=02\end{array}$ \\
\hline
\end{tabular}


International Journal of Engineering Applied Sciences and Technology, 2020

Vol. 4, Issue 9, ISSN No. 2455-2143, Pages 241-271

Published Online January 2020 in IJEAST (http://www.ijeast.com)

\begin{tabular}{|c|c|c|c|c|c|}
\hline Net-Phase of Exon/Signal & $\begin{array}{l}E-1=01 \\
E-2=02 \\
E-3=()\end{array}$ & $\begin{array}{l}\mathrm{E}-1=01 \\
\mathrm{E}-2=02 \\
\mathrm{E}-3=()\end{array}$ & $\begin{array}{l}\text { E-1 }=01 \\
\text { E-2 }=02\end{array}$ & $\begin{array}{l}\mathrm{E}-1=02 \\
\mathrm{E}-2=02\end{array}$ & $\begin{array}{l}\mathrm{E}-1=01 \\
\mathrm{E}-2=00\end{array}$ \\
\hline $\begin{array}{l}\text { Initiation signal/3'-Splice } \\
\text { site score }\end{array}$ & $\begin{array}{l}\mathrm{E}-1=84 \\
\mathrm{E}-2=35 \\
\mathrm{E}-3=()\end{array}$ & $\begin{array}{l}E-1=87 \\
E-2=-37 \\
E-3=()\end{array}$ & $\begin{array}{l}\text { E-1 }=82 \\
\text { E-2 }=-50\end{array}$ & $\begin{array}{l}\mathrm{E}-1=39 \\
\mathrm{E}-2=-12\end{array}$ & $\begin{array}{l}E-1=87 \\
E-2=34\end{array}$ \\
\hline $\begin{array}{l}\text { Termination signal/5'-Splice } \\
\text { site score }\end{array}$ & $\begin{array}{l}\mathrm{E}-1=92 \\
\mathrm{E}-2=43 \\
\mathrm{E}-3=()\end{array}$ & $\begin{array}{l}\mathrm{E}-1=36 \\
\mathrm{E}-2=33 \\
\mathrm{E}-3=()\end{array}$ & $\begin{array}{l}\mathrm{E}-1=-4 \\
\mathrm{E}-2=42\end{array}$ & $\begin{array}{l}\mathrm{E}-1=-12 \\
\mathrm{E}-2=72\end{array}$ & $\begin{array}{l}\mathrm{E}-1=97 \\
\mathrm{E}-2=67\end{array}$ \\
\hline Coding Region score & $\begin{array}{l}\mathrm{E}-1=285 \\
\mathrm{E}-2=497 \\
\mathrm{E}-3=()\end{array}$ & $\begin{array}{l}\mathrm{E}-1=496 \\
\mathrm{E}-2=430 \\
\mathrm{E}-3=()\end{array}$ & $\begin{array}{l}\text { E-1 }=305 \\
\text { E-2 }=578\end{array}$ & $\begin{array}{l}\mathrm{E}-1=423 \\
\mathrm{E}-2=611\end{array}$ & $\begin{array}{l}\text { E-1 }=415 \\
\text { E-2 }=425\end{array}$ \\
\hline Probability of Exon & $\begin{array}{l}\text { E-1 }=0.896 \\
\text { E-2 }=0.979 \\
\text { E-3 }=()\end{array}$ & $\begin{array}{l}\text { E-1 }=0.908 \\
\text { E-2 }=0.134 \\
\text { E-3 }=()\end{array}$ & $\begin{array}{l}\text { E-1 }=0.237 \\
\text { E-2 }=0.309\end{array}$ & $\begin{array}{l}\text { E-1 }=0.365 \\
\text { E-2 }=0.734\end{array}$ & $\begin{array}{l}\mathrm{E}-1=0.835 \\
\mathrm{E}-2=0.362\end{array}$ \\
\hline Exon score & $\begin{array}{l}\mathrm{E}-1=23.30 \\
\mathrm{E}-2=32.16 \\
\mathrm{E}-3=1.05\end{array}$ & $\begin{array}{l}\mathrm{E}-1=39.10 \\
\text { E-2 }=17.20 \\
\text { E-3 }=1.05\end{array}$ & $\begin{array}{l}\text { E-1 }=15.51 \\
\text { E-2 }=31.64\end{array}$ & $\begin{array}{l}\mathrm{E}-1=18.94 \\
\mathrm{E}-2=39.43\end{array}$ & $\begin{array}{l}\mathrm{E}-1=37.09 \\
\mathrm{E}-2=26.36\end{array}$ \\
\hline
\end{tabular}

\section{Spike Glvcoprotein:}

\begin{tabular}{|c|c|c|c|c|c|}
\hline & Tai Forest Ebolavirus & Bundibugyo Ebolavirus & Sudan Ebolavirus & Zaire Ebolavirus & Reston Ebolavirus \\
\hline \multirow[t]{3}{*}{$\begin{array}{l}\text { Gene number;Exon number } \\
\text { and Exon type }\end{array}$} & $\begin{array}{l}\text { Gene number }=01 \\
\text { Exon number }=01 \\
\text { Type of Exon }=\text { Init }\end{array}$ & $\begin{array}{l}\text { Gene number }=01 \\
\text { Exon number }=01 \\
\text { Type of Exon }=\text { Init }\end{array}$ & $\begin{array}{l}\text { Gene number }=01 \\
\text { Exon number }=01 \\
\text { Type of Exon }=\text { Init }\end{array}$ & $\begin{array}{l}\text { Gene number }=01 \\
\text { Exon number }=01 \\
\text { Type of Exon }=\text { Intr }\end{array}$ & $\begin{array}{l}\text { Gene number }=01 \\
\text { Exon number }=01 \\
\text { Type of Exon }=\text { Init }\end{array}$ \\
\hline & $\begin{array}{l}\text { Gene number }=01 \\
\text { Exon number }=02 \\
\text { Type of Exon }=\text { Term }\end{array}$ & $\begin{array}{l}\text { Gene number }=01 \\
\text { Exon number }=02 \\
\text { Type of Exon }=\text { Term }\end{array}$ & $\begin{array}{l}\text { Gene number }=01 \\
\text { Exon number }=02 \\
\text { Type of Exon }=\text { Term }\end{array}$ & $\begin{array}{l}\text { Gene number }=01 \\
\text { Exon number }=02 \\
\text { Type of Exon }=\text { Intr }\end{array}$ & $\begin{array}{l}\text { Gene number }=01 \\
\text { Exon number }=02 \\
\text { Type of Exon }=\text { Intr }\end{array}$ \\
\hline & $\begin{array}{l}\text { Gene number }=01 \\
\text { Exon number }=02 \\
\text { Type of Exon }=\text { PlyA }\end{array}$ & $\begin{array}{l}\text { Gene number }=01 \\
\text { Exon number }=03 \\
\text { Type of Exon }=\text { PlyA }\end{array}$ & & & \\
\hline $\begin{array}{l}\text { Type of DNA Strand } \\
+=\text { Input Strand } \\
-=\text { Output Strand }\end{array}$ & $\begin{array}{l}\text { E-1(+= Input Strand) } \\
\text { E-2(+= Input Strand) } \\
\text { E-3(+= Input Strand) }\end{array}$ & $\begin{array}{l}\text { E-1(+= Input Strand) } \\
\text { E-2(+ = Input Strand) } \\
\text { E-3(+= Input Strand) }\end{array}$ & $\begin{array}{l}\text { E-1(+ = Input Strand) } \\
\text { E-2(+= Input Strand })\end{array}$ & $\begin{array}{l}\text { E-1(+= Input Strand) } \\
\text { E-2(+= Input Strand) }\end{array}$ & $\begin{array}{l}\text { E-1(+ }=\text { Input Strand }) \\
\text { E-2(+ = Input Strand })\end{array}$ \\
\hline Beginning of Exon/Signal & $\begin{array}{l}\mathrm{E}-1=140 \\
\mathrm{E}-2=1076 \\
\mathrm{E}-3=2356\end{array}$ & $\begin{array}{l}\mathrm{E}-1=140 \\
\mathrm{E}-2=1052 \\
\mathrm{E}-3=2373\end{array}$ & $\begin{array}{l}\mathrm{E}-1=116 \\
\mathrm{E}-2=1043\end{array}$ & $\begin{array}{l}\mathrm{E}-1=425 \\
\mathrm{E}-2=1035\end{array}$ & $\begin{array}{l}\mathrm{E}-1=142 \\
\mathrm{E}-2=1102\end{array}$ \\
\hline Ending of Exon/signal & $\begin{array}{l}\mathrm{E}-1=995 \\
\mathrm{E}-2=2169 \\
\mathrm{E}-3=2361\end{array}$ & $\begin{array}{l}\mathrm{E}-1=995 \\
\mathrm{E}-2=2169 \\
\mathrm{E}-3=2378\end{array}$ & $\begin{array}{l}\text { E-1 }=971 \\
\text { E-2 }=2145\end{array}$ & $\begin{array}{l}\mathrm{E}-1=999 \\
\mathrm{E}-2=2101\end{array}$ & $\begin{array}{l}\mathrm{E}-1=1000 \\
\mathrm{E}-2=1938\end{array}$ \\
\hline Length of Exon/signal & $\begin{array}{l}\mathrm{E}-1=856 \\
\mathrm{E}-2=1094 \\
\mathrm{E}-3=06\end{array}$ & $\begin{array}{l}\mathrm{E}-1=856 \\
\mathrm{E}-2=1118 \\
\mathrm{E}-3=06\end{array}$ & $\begin{array}{l}\text { E-1 }=856 \\
\text { E-2 }=1103\end{array}$ & $\begin{array}{l}\mathrm{E}-1=575 \\
\mathrm{E}-2=1067\end{array}$ & $\begin{array}{l}\mathrm{E}-1=859 \\
\mathrm{E}-2=837\end{array}$ \\
\hline Reading Frame & $\begin{array}{l}\mathrm{E}-1=01 \\
\mathrm{E}-2=00 \\
\mathrm{E}-3=()\end{array}$ & $\begin{array}{l}\mathrm{E}-1=01 \\
\mathrm{E}-2=00 \\
\mathrm{E}-3=()\end{array}$ & $\begin{array}{l}\mathrm{E}-1=01 \\
\mathrm{E}-2=00\end{array}$ & $\begin{array}{l}\mathrm{E}-1=01 \\
\mathrm{E}-2=00\end{array}$ & $\begin{array}{l}\mathrm{E}-1=00 \\
\mathrm{E}-2=02\end{array}$ \\
\hline Net-Phase of Exon/Signal & $\begin{array}{l}\mathrm{E}-1=01 \\
\mathrm{E}-2=02 \\
\mathrm{E}-3=(\mathrm{C})\end{array}$ & $\begin{array}{l}\mathrm{E}-1=01 \\
\mathrm{E}-2=02 \\
\mathrm{E}-3=()\end{array}$ & $\begin{array}{l}\mathrm{E}-1=01 \\
\mathrm{E}-2=02\end{array}$ & $\begin{array}{l}\mathrm{E}-1=02 \\
\mathrm{E}-2=02\end{array}$ & $\begin{array}{l}\mathrm{E}-1=01 \\
\mathrm{E}-2=00\end{array}$ \\
\hline $\begin{array}{l}\text { Initiation signal/3'-Splice } \\
\text { site score }\end{array}$ & $\begin{array}{l}\mathrm{E}-1=84 \\
\mathrm{E}-2=35 \\
\mathrm{E}-3=()\end{array}$ & $\begin{array}{l}\mathrm{E}-1=87 \\
\mathrm{E}-2=-37 \\
\mathrm{E}-3=()\end{array}$ & $\begin{array}{l}\mathrm{E}-1=82 \\
\mathrm{E}-2=-50\end{array}$ & $\begin{array}{l}E-1=39 \\
E-2=-12\end{array}$ & $\begin{array}{l}\mathrm{E}-1=87 \\
\mathrm{E}-2=34\end{array}$ \\
\hline $\begin{array}{l}\text { Termination signal/5'-Splice } \\
\text { site score }\end{array}$ & $\begin{array}{l}\mathrm{E}-1=92 \\
\mathrm{E}-2=43 \\
\mathrm{E}-3=()\end{array}$ & $\begin{array}{l}\mathrm{E}-1=36 \\
\mathrm{E}-2=33 \\
\mathrm{E}-3=()\end{array}$ & $\begin{array}{l}\mathrm{E}-1=-4 \\
\mathrm{E}-2=42\end{array}$ & $\begin{array}{l}\mathrm{E}-1=-12 \\
\mathrm{E}-2=72\end{array}$ & $\begin{array}{l}\mathrm{E}-1=97 \\
\mathrm{E}-2=67\end{array}$ \\
\hline
\end{tabular}


International Journal of Engineering Applied Sciences and Technology, 2020

Vol. 4, Issue 9, ISSN No. 2455-2143, Pages 241-271

Published Online January 2020 in IJEAST (http://www.ijeast.com)

\begin{tabular}{|c|c|c|c|c|c|}
\hline Coding Region score & $\begin{array}{l}\mathrm{E}-1=285 \\
\mathrm{E}-2=497 \\
\mathrm{E}-3=()\end{array}$ & $\begin{array}{l}E-1=496 \\
E-2=430 \\
E-3=()\end{array}$ & $\begin{array}{l}E-1=305 \\
E-2=578\end{array}$ & $\begin{array}{l}\mathrm{E}-1=423 \\
\mathrm{E}-2=611\end{array}$ & $\begin{array}{l}E-1=415 \\
E-2=425\end{array}$ \\
\hline Probability of Exon & $\begin{array}{l}\text { E-1 }=0.896 \\
\text { E-2 }=0.979 \\
\text { E-3 }=()\end{array}$ & $\begin{array}{l}\text { E-1 }=0.908 \\
\text { E-2 }=0.134 \\
\text { E-3 }=()\end{array}$ & $\begin{array}{l}E-1=0.237 \\
E-2=0.309\end{array}$ & $\begin{array}{l}E-1=0.365 \\
E-2=0.734\end{array}$ & $\begin{array}{l}\mathrm{E}-1=0.835 \\
\mathrm{E}-2=0.362\end{array}$ \\
\hline Exon score & $\begin{array}{l}\text { E-1 }=23.30 \\
\text { E-2 }=32.16 \\
\text { E-3 }=1.05\end{array}$ & $\begin{array}{l}E-1=39.10 \\
E-2=17.20 \\
E-3=1.05\end{array}$ & $\begin{array}{l}\text { E-1 }=15.51 \\
\text { E-2 }=31.64\end{array}$ & $\begin{array}{l}\text { E-1 }=18.94 \\
\text { E-2 }=39.43\end{array}$ & $\begin{array}{l}\text { E-1 }=37.09 \\
\text { E-2 }=26.36\end{array}$ \\
\hline
\end{tabular}

RNA Dependent RNA Polvmerase:

\begin{tabular}{|c|c|c|c|c|c|}
\hline & Tai Forest Ebolavirus & Bundibugyo Ebolavirus & Sudan Ebolavirus & Zaire Ebolavirus & Reston Ebolavirus \\
\hline \multirow[t]{2}{*}{$\begin{array}{l}\text { Gene number;Exon number } \\
\text { and Exon type }\end{array}$} & $\begin{array}{l}\text { Gene number }=01 \\
\text { Exon number }=01 \\
\text { Type of Exon }=\text { Sngl }\end{array}$ & $\begin{array}{l}\text { Gene number }=01 \\
\text { Exon number }=01 \\
\text { Type of exon }=\text { Sngl }\end{array}$ & $\begin{array}{l}\text { Gene number }=01 \\
\text { Exon number }=01 \\
\text { Type of Exon }=\text { Sngl }\end{array}$ & $\begin{array}{l}\text { Gene number }=01 \\
\text { Exon number }=01 \\
\text { Type of Exon }=\text { Sngl }\end{array}$ & $\begin{array}{l}\text { Gene number }=01 \\
\text { Exon number }=01 \\
\text { Type of Exon }=\text { Sngl }\end{array}$ \\
\hline & $\begin{array}{l}\text { Gene number }=01 \\
\text { Exon number }=02 \\
\text { Type of Exon }=\text { PlyA }\end{array}$ & $\begin{array}{l}\text { Gene number }=01 \\
\text { Exon number }=02 \\
\text { Type of Exon }=\text { PlyA }\end{array}$ & $\begin{array}{l}\text { Gene number }=01 \\
\text { Exon number }=02 \\
\text { Type of Exon }=\text { PlyA }\end{array}$ & $\begin{array}{l}\text { Gene number }=01 \\
\text { Exon number }=02 \\
\text { Type of Exon }=\text { PlyA }\end{array}$ & $\begin{array}{l}\text { Gene number }=01 \\
\text { Exon number }=02 \\
\text { Type of Exon }=\text { PlyA }\end{array}$ \\
\hline $\begin{array}{l}\text { Type of DNA Strand } \\
+=\text { Input Strand } \\
-=\text { Output Strand }\end{array}$ & $\begin{array}{l}\text { E-1(+ = Input Strand) } \\
\text { E-2(+ = Input Strand) }\end{array}$ & $\begin{array}{l}\text { E-1(+= Input Strand) } \\
\text { E-2(+= Input Strand) }\end{array}$ & $\begin{array}{l}\text { E-1(+ = Input Strand }) \\
\text { E-2(+ = Input Strand })\end{array}$ & $\begin{array}{l}\text { E-1(+ = Input Strand }) \\
\text { E-2(+= Input Strand })\end{array}$ & $\begin{array}{l}\text { E-1(+ }+ \text { Input Strand }) \\
\text { E-2(+= Input Strand })\end{array}$ \\
\hline Beginning of Exon/Signal & $\begin{array}{l}\mathrm{E}-1=81 \\
\mathrm{E}-2=6959\end{array}$ & $\begin{array}{l}\mathrm{E}-1=81 \\
\mathrm{E}-2=6803\end{array}$ & $\begin{array}{l}\mathrm{E}-1=82 \\
\mathrm{E}-2=6986\end{array}$ & $\begin{array}{l}\mathrm{E}-1=81 \\
\mathrm{E}-2=6775\end{array}$ & $\begin{array}{l}\mathrm{E}-1=87 \\
\mathrm{E}-2=7202\end{array}$ \\
\hline Ending of Exon/signal & $\begin{array}{l}\mathrm{E}-1=6713 \\
\mathrm{E}-2=6964\end{array}$ & $\begin{array}{l}\mathrm{E}-1=6713 \\
\mathrm{E}-2=6808\end{array}$ & $\begin{array}{l}\mathrm{E}-1=6711 \\
\mathrm{E}-2=6991\end{array}$ & $\begin{array}{l}\mathrm{E}-1=6719 \\
\mathrm{E}-2=6780\end{array}$ & $\begin{array}{l}\mathrm{E}-1=6725 \\
\mathrm{E}-2=7207\end{array}$ \\
\hline Length of Exon/signal & $\begin{array}{l}\mathrm{E}-1=6633 \\
\mathrm{E}-2=06\end{array}$ & $\begin{array}{l}\mathrm{E}-1=6633 \\
\mathrm{E}-2=06\end{array}$ & $\begin{array}{l}\mathrm{E}-1=6630 \\
\mathrm{E}-2=06\end{array}$ & $\begin{array}{l}\mathrm{E}-1=6639 \\
\mathrm{E}-2=06\end{array}$ & $\begin{array}{l}\mathrm{E}-1=6639 \\
\mathrm{E}-2=06\end{array}$ \\
\hline Reading Frame & $\begin{array}{l}\mathrm{E}-1=02 \\
\mathrm{E}-2=(\mathrm{J})\end{array}$ & $\begin{array}{l}E-1=02 \\
E-2=()\end{array}$ & $\begin{array}{l}\mathrm{E}-1=00 \\
\mathrm{E}-2=(\mathrm{)}\end{array}$ & $\begin{array}{l}\mathrm{E}-1=02 \\
\mathrm{E}-2=00\end{array}$ & $\begin{array}{l}E-1=02 \\
E-2=()\end{array}$ \\
\hline Net-Phase of Exon/Signal & $\begin{array}{l}\mathrm{E}-1=00 \\
\mathrm{E}-2=()\end{array}$ & $\begin{array}{l}\mathrm{E}-1=00 \\
\mathrm{E}-2=(\mathrm{)}\end{array}$ & $\begin{array}{l}E-1=00 \\
E-2=()\end{array}$ & $\begin{array}{l}\mathrm{E}-1=00 \\
\mathrm{E}-2=00\end{array}$ & $\begin{array}{l}E-1=00 \\
E-2=()\end{array}$ \\
\hline $\begin{array}{l}\text { Initiation signal/3'-Splice } \\
\text { site score }\end{array}$ & $\begin{array}{l}\mathrm{E}-1=87 \\
\mathrm{E}-2=()\end{array}$ & $\begin{array}{l}\mathrm{E}-1=36 \\
\mathrm{E}-2=(\mathrm{)}\end{array}$ & $\begin{array}{l}\mathrm{E}-1=52 \\
\mathrm{E}-2=()\end{array}$ & $\begin{array}{l}\mathrm{E}-1=15 \\
\mathrm{E}-2=(\mathrm{)}\end{array}$ & $\begin{array}{l}\mathrm{E}-1=40 \\
\mathrm{E}-2=()\end{array}$ \\
\hline $\begin{array}{l}\text { Termination signal/5'-Splice } \\
\text { site score }\end{array}$ & $\begin{array}{l}\mathrm{E}-1=49 \\
\mathrm{E}-2=()\end{array}$ & $\begin{array}{l}\mathrm{E}-1=44 \\
\mathrm{E}-2=()\end{array}$ & $\begin{array}{l}\mathrm{E}-1=31 \\
\mathrm{E}-2=()\end{array}$ & $\begin{array}{l}\mathrm{E}-1=38 \\
\mathrm{E}-2=()\end{array}$ & $\begin{array}{l}\mathrm{E}-1=43 \\
\mathrm{E}-2=()\end{array}$ \\
\hline Coding Region score & $\begin{array}{l}\mathrm{E}-1=2393 \\
\mathrm{E}-2=()\end{array}$ & $\begin{array}{l}\mathrm{E}-1=2459 \\
\mathrm{E}-2=()\end{array}$ & $\begin{array}{l}\mathrm{E}-1=2403 \\
\mathrm{E}-2=()\end{array}$ & $\begin{array}{l}\mathrm{E}-1=2927 \\
\mathrm{E}-2=()\end{array}$ & $\begin{array}{l}\mathrm{E}-1=2884 \\
\mathrm{E}-2=()\end{array}$ \\
\hline Probability of Exon & $\begin{array}{l}\mathrm{E}-1=0.884 \\
\mathrm{E}-2=()\end{array}$ & $\begin{array}{l}\mathrm{E}-1=0.996 \\
\mathrm{E}-2=()\end{array}$ & $\begin{array}{l}\mathrm{E}-1=0.967 \\
\mathrm{E}-2=()\end{array}$ & $\begin{array}{l}\mathrm{E}-1=0.972 \\
\mathrm{E}-2=()\end{array}$ & $\begin{array}{l}\mathrm{E}-1=0.975 \\
\mathrm{E}-2=()\end{array}$ \\
\hline Exon score & $\begin{array}{l}\mathrm{E}-1=227.53 \\
\mathrm{E}-2=-3.44\end{array}$ & $\begin{array}{l}\mathrm{E}-1=228.53 \\
\mathrm{E}-2=-0.45\end{array}$ & $\begin{array}{l}\mathrm{E}-1=223.23 \\
\mathrm{E}-2=-1.75\end{array}$ & $\begin{array}{l}\mathrm{E}-1=272.63 \\
\mathrm{E}-2=-3.44\end{array}$ & $\begin{array}{l}\mathrm{E}-1=271.33 \\
\mathrm{E}-2=1.05\end{array}$ \\
\hline
\end{tabular}

\section{Membrane Associated Protein:}

\begin{tabular}{|l|l|l|l|l|l|}
\hline & Tai Forest Ebolavirus & Bundibugyo Ebolavirus & Sudan Ebolavirus & Zaire Ebolavirus & Reston Ebolavirus \\
\hline $\begin{array}{l}\text { Gene number; Exon number } \\
\text { and Exon type }\end{array}$ & $\begin{array}{l}\text { Gene number }=01 \\
\text { Exon number }=01 \\
\text { Type of Exon }=\text { Term }\end{array}$ & $\begin{array}{l}\text { Gene number }=01 \\
\text { Exon number }=01 \\
\text { Type of Exon }=\text { Sngl }\end{array}$ & $\begin{array}{l}\text { Gene number }=01 \\
\text { Exon number }=01 \\
\text { Type of Exon }=\text { Sngl }\end{array}$ & $\begin{array}{l}\text { Gene number }=01 \\
\text { Exon number }=01 \\
\text { Type of Exon }=\text { Sngl }\end{array}$ & $\begin{array}{l}\text { Gene number }=01 \\
\text { Exon number }=01 \\
\text { Type of Exon }=\text { Sngl }\end{array}$ \\
\cline { 2 - 6 } & $\begin{array}{l}\text { Gene number }=01 \\
\text { Exon number }=02 \\
\text { Type of Exon }=\text { PlyA }\end{array}$ & $\begin{array}{l}\text { Gene number }=01 \\
\text { Exon number }=02 \\
\text { Type of Exon }=\text { PlyA }\end{array}$ & $\begin{array}{l}\text { Gene number }=01 \\
\text { Exon number }=02 \\
\text { Type of Exon }=\text { PlyA }\end{array}$ & $\begin{array}{l}\text { Gene number }=01 \\
\text { Exon number }=02 \\
\text { Type of Exon }=\text { PlyA }\end{array}$ & $\begin{array}{l}\text { Gene number }=01 \\
\text { Exon number }=02 \\
\text { Type of Exon }=\text { PlyA }\end{array}$ \\
\hline Type of DNA Strand & E-1(+= Input Strand $)$ & E-1(+ = Input Strand) & E-1(+= Input Strand $)$ & E-1(+= Input Strand) & E-1(+= Input Strand) \\
\hline
\end{tabular}


International Journal of Engineering Applied Sciences and Technology, 2020

Vol. 4, Issue 9, ISSN No. 2455-2143, Pages 241-271

Published Online January 2020 in IJEAST (http://www.ijeast.com)

\begin{tabular}{|c|c|c|c|c|c|}
\hline $\begin{array}{l}+=\text { Input Strand } \\
-=\text { Output Strand }\end{array}$ & E-2(+ = Input Strand) & E-2(+= Input Strand) & E-2(+ = Input Strand) & E-2(+= Input Strand) & E-2(+= Input Strand) \\
\hline Beginning of Exon/Signal & $\begin{array}{l}E-1=327 \\
E-2=1439\end{array}$ & $\begin{array}{l}\text { E-1 }=467 \\
\text { E-2 }=1348\end{array}$ & $\begin{array}{l}\text { E-1 }=474 \\
\text { E-2 }=1237\end{array}$ & $\begin{array}{l}\text { E-1 }=461 \\
\text { E-2 }=1310\end{array}$ & $\begin{array}{l}\text { E-1 }=472 \\
\text { E-2 }=1241\end{array}$ \\
\hline Ending of Exon/signal & $\begin{array}{l}\text { E-1 }=1222 \\
\text { E-2 }=1444\end{array}$ & $\begin{array}{l}\text { E-1 }=1222 \\
\text { E-2 }=1353\end{array}$ & $\begin{array}{l}\text { E-1 }=1229 \\
\text { E-2 }=1242\end{array}$ & $\begin{array}{l}\text { E-1 }=1216 \\
\text { E-2 }=1315\end{array}$ & $\begin{array}{l}\mathrm{E}-1=1227 \\
\mathrm{E}-2=1246\end{array}$ \\
\hline Length of Exon/signal & $\begin{array}{l}E-1=896 \\
E-2=06\end{array}$ & $\begin{array}{l}E-1=756 \\
E-2=06\end{array}$ & $\begin{array}{l}\mathrm{E}-1=756 \\
\mathrm{E}-2=06\end{array}$ & $\begin{array}{l}E-1=756 \\
E-2=06\end{array}$ & $\begin{array}{l}\mathrm{E}-1=756 \\
\mathrm{E}-2=06\end{array}$ \\
\hline Reading Frame & $\begin{array}{l}E-1=01 \\
E-2=()\end{array}$ & $\begin{array}{l}E-1=01 \\
E-2=()\end{array}$ & $\begin{array}{l}E-1=02 \\
E-2=()\end{array}$ & $\begin{array}{l}E-1=01 \\
E-2=()\end{array}$ & $\begin{array}{l}\mathrm{E}-1=00 \\
\mathrm{E}-2=()\end{array}$ \\
\hline Net-Phase of Exon/Signal & $\begin{array}{l}E-1=02 \\
E-2=()\end{array}$ & $\begin{array}{l}E-1=00 \\
E-2=()\end{array}$ & $\begin{array}{l}E-1=00 \\
E-2=()\end{array}$ & $\begin{array}{l}E-1=00 \\
E-2=()\end{array}$ & $\begin{array}{l}\mathrm{E}-1=00 \\
\mathrm{E}-2=()\end{array}$ \\
\hline $\begin{array}{l}\text { Initiation signal/3'-Splice } \\
\text { site score }\end{array}$ & $\begin{array}{l}E-1=45 \\
E-2=()\end{array}$ & $\begin{array}{l}E-1=80 \\
E-2=()\end{array}$ & $\begin{array}{l}E-1=80 \\
E-2=()\end{array}$ & $\begin{array}{l}E-1=88 \\
E-2=()\end{array}$ & $\begin{array}{l}E-1=83 \\
E-2=()\end{array}$ \\
\hline $\begin{array}{l}\text { Termination signal/5'-Splice } \\
\text { site score }\end{array}$ & $\begin{array}{l}E-1=35 \\
E-2=()\end{array}$ & $\begin{array}{l}E-1=37 \\
E-2=()\end{array}$ & $\begin{array}{l}E-1=32 \\
E-2=()\end{array}$ & $\begin{array}{l}E-1=36 \\
E-2=()\end{array}$ & $\begin{array}{l}E-1=42 \\
E-2=()\end{array}$ \\
\hline Coding Region score & $\begin{array}{l}E-1=535 \\
E-2=()\end{array}$ & $\begin{array}{l}E-1=450 \\
E-2=()\end{array}$ & $\begin{array}{l}E-1=504 \\
E-2=()\end{array}$ & $\begin{array}{l}\mathrm{E}-1=622 \\
\mathrm{E}-2=()\end{array}$ & $\begin{array}{l}E-1=299 \\
E-2=()\end{array}$ \\
\hline Probability of Exon & $\begin{array}{l}\mathrm{E}-1=0.795 \\
\mathrm{E}-2=()\end{array}$ & $\begin{array}{l}\mathrm{E}-1=0.776 \\
\mathrm{E}-2=()\end{array}$ & $\begin{array}{l}\mathrm{E}-1=0.992 \\
\mathrm{E}-2=()\end{array}$ & $\begin{array}{l}\mathrm{E}-1=0.999 \\
\mathrm{E}-2=()\end{array}$ & $\begin{array}{l}\mathrm{E}-1=0.922 \\
\mathrm{E}-2=()\end{array}$ \\
\hline Exon score & $\begin{array}{l}\mathrm{E}-1=35.47 \\
\mathrm{E}-2=-1.75\end{array}$ & $\begin{aligned} E-1 & =34.99 \\
E-2 & =1.05\end{aligned}$ & $\begin{aligned} E-1 & =39.89 \\
E-2 & =1.05\end{aligned}$ & $\begin{aligned} E-1 & =52.89 \\
E-2 & =1.05\end{aligned}$ & $\begin{array}{l}\mathrm{E}-1=20.69 \\
\mathrm{E}-2=-3.24\end{array}$ \\
\hline
\end{tabular}

\section{Minor Nucleoprotein:}

\begin{tabular}{|c|c|c|c|c|c|}
\hline & Tai Forest Ebolavirus & Bundibugyo Ebolavirus & Sudan Ebolavirus & Zaire Ebolavirus & Reston Ebolavirus \\
\hline \multirow[t]{2}{*}{$\begin{array}{l}\text { Gene number;Exon number } \\
\text { and Exon type }\end{array}$} & $\begin{array}{l}\text { Gene number }=01 \\
\text { Exon number }=01 \\
\text { Type of Exon }=\text { Sngl }\end{array}$ & $\begin{array}{l}\text { Gene number }=01 \\
\text { Exon number }=01 \\
\text { Type of Exon }=\text { Sngl }\end{array}$ & $\begin{array}{l}\text { Gene number }=01 \\
\text { Exon number }=01 \\
\text { Type of Exon }=\text { Sngl }\end{array}$ & $\begin{array}{l}\text { Gene number }=01 \\
\text { Exon number }=01 \\
\text { Type of Exon=Sngl }\end{array}$ & $\begin{array}{l}\text { Gene number }=01 \\
\text { Exon number }=01 \\
\text { Type of Exon }=\text { Sngl }\end{array}$ \\
\hline & $\begin{array}{l}\text { Gene number }=01 \\
\text { Exon number }=02 \\
\text { Type of Exon }=\text { PlyA }\end{array}$ & $\begin{array}{l}\text { Gene number }=01 \\
\text { Exon number }=02 \\
\text { Type of Exon }=\text { PlyA }\end{array}$ & $\begin{array}{l}\text { Gene number }=01 \\
\text { Exon number }=02 \\
\text { Type of Exon }=\text { PlyA }\end{array}$ & $\begin{array}{l}\text { Gene number }=01 \\
\text { Exon number }=02 \\
\text { Type of Exon }=\text { PlyA }\end{array}$ & $\begin{array}{l}\text { Gene number }=01 \\
\text { Exon number }=02 \\
\text { Type of Exon }=\text { PlyA }\end{array}$ \\
\hline $\begin{array}{l}\text { Type of DNA Strand } \\
+=\text { Input Strand } \\
\text { - = Output Strand }\end{array}$ & $\begin{array}{l}\text { E-1(+ = Input Strand }) \\
\text { E-2(+ = Input Strand })\end{array}$ & $\begin{array}{l}\text { E-1(+ = Input Strand) } \\
\text { E-2(+ = Input Strand) }\end{array}$ & $\begin{array}{l}\text { E-1(+ }=\text { Input Strand }) \\
\text { E-2(+ = Input Strand })\end{array}$ & $\begin{array}{l}\text { E-1(+ = Input Strand }) \\
\text { E-2(+= Input Strand) }\end{array}$ & $\begin{array}{l}\text { E-1(+ = Input Strand }) \\
\text { E-2(+= Input Strand })\end{array}$ \\
\hline Beginning of Exon/Signal & $\begin{array}{l}\mathrm{E}-1=228 \\
\mathrm{E}-2=1174\end{array}$ & $\begin{array}{l}\mathrm{E}-1=228 \\
\mathrm{E}-2=1174\end{array}$ & $\begin{array}{l}\mathrm{E}-1=218 \\
\mathrm{E}-2=1161\end{array}$ & $\begin{array}{l}\mathrm{E}-1=222 \\
\mathrm{E}-2=1401\end{array}$ & $\begin{array}{l}\mathrm{E}-1=229 \\
\mathrm{E}-2=1132\end{array}$ \\
\hline Ending of Exon/signal & $\begin{array}{l}\mathrm{E}-1=1097 \\
\mathrm{E}-2=1179\end{array}$ & $\begin{array}{l}\mathrm{E}-1=1097 \\
\mathrm{E}-2=1179\end{array}$ & $\begin{array}{l}\mathrm{E}-1=1084 \\
\mathrm{E}-2=1166\end{array}$ & $\begin{array}{l}\mathrm{E}-1=1088 \\
\mathrm{E}-2=1406\end{array}$ & $\begin{array}{l}\mathrm{E}-1=1092 \\
\mathrm{E}-2=1137\end{array}$ \\
\hline Length of Exon/signal & $\begin{array}{l}\mathrm{E}-1=870 \\
\mathrm{E}-1=06\end{array}$ & $\begin{array}{l}\text { E-1 }=870 \\
\text { E-2 }=06\end{array}$ & $\begin{array}{l}\text { E-1 }=867 \\
\text { E-2 }=06\end{array}$ & $\begin{array}{l}\text { E-1 }=867 \\
\text { E-2 }=06\end{array}$ & $\begin{array}{l}\mathrm{E}-1=864 \\
\mathrm{E}-2=06\end{array}$ \\
\hline Reading Frame & $\begin{array}{l}\mathrm{E}-1=02 \\
\mathrm{E}-2=(\mathrm{)}\end{array}$ & $\begin{array}{l}\mathrm{E}-1=02 \\
\mathrm{E}-2=(\mathrm{)}\end{array}$ & $\begin{array}{l}\mathrm{E}-1=01 \\
\mathrm{E}-2=(\mathrm{)}\end{array}$ & $\begin{array}{l}\mathrm{E}-1=02 \\
\mathrm{E}-2=(\mathrm{)}\end{array}$ & $\begin{array}{l}\mathrm{E}-1=00 \\
\mathrm{E}-2=()\end{array}$ \\
\hline Net-Phase of Exon/Signal & $\begin{array}{l}E-1=00 \\
E-2=()\end{array}$ & $\begin{array}{l}\mathrm{E}-1=00 \\
\mathrm{E}-2=()\end{array}$ & $\begin{array}{l}\mathrm{E}-1=00 \\
\mathrm{E}-2=()\end{array}$ & $\begin{array}{l}\mathrm{E}-1=00 \\
\mathrm{E}-2=()\end{array}$ & $\begin{array}{l}\mathrm{E}-1=00 \\
\mathrm{E}-2=()\end{array}$ \\
\hline $\begin{array}{l}\text { Initiation signal/3'-Splice } \\
\text { site score }\end{array}$ & $\begin{array}{l}E-1=78 \\
E-2=()\end{array}$ & $\begin{array}{l}\mathrm{E}-1=52 \\
\mathrm{E}-2=()\end{array}$ & $\begin{array}{l}\mathrm{E}-1=73 \\
\mathrm{E}-2=()\end{array}$ & $\begin{array}{l}\mathrm{E}-1=06 \\
\mathrm{E}-2=()\end{array}$ & $\begin{array}{l}\mathrm{E}-1=77 \\
\mathrm{E}-2=()\end{array}$ \\
\hline $\begin{array}{l}\text { Termination signal/5'-Splice } \\
\text { site score }\end{array}$ & $\begin{array}{l}\mathrm{E}-1=48 \\
\mathrm{E}-2=(\mathrm{C}\end{array}$ & $\begin{array}{l}\mathrm{E}-1=38 \\
\mathrm{E}-2=(\mathrm{)}\end{array}$ & $\begin{array}{l}\mathrm{E}-1=38 \\
\mathrm{E}-2=(\mathrm{)}\end{array}$ & $\begin{array}{l}E-1=38 \\
E-2=()\end{array}$ & $\begin{array}{l}\mathrm{E}-1=43 \\
\mathrm{E}-2=(\mathrm{)}\end{array}$ \\
\hline Coding Region score & $\begin{array}{l}\mathrm{E}-1=595 \\
\mathrm{E}-2=()\end{array}$ & $\begin{array}{l}\mathrm{E}-1=540 \\
\mathrm{E}-2=()\end{array}$ & $\begin{array}{l}\mathrm{E}-1=513 \\
\mathrm{E}-2=()\end{array}$ & $\begin{array}{l}\mathrm{E}-1=414 \\
\mathrm{E}-2=()\end{array}$ & $\begin{array}{l}\mathrm{E}-1=566 \\
\mathrm{E}-2=()\end{array}$ \\
\hline & & & & & \\
\hline Probability of Exon & $\begin{array}{l}E-1=0.990 \\
E-2=()\end{array}$ & $\begin{array}{l}E-1=0.865 \\
E-2=()\end{array}$ & $\begin{array}{l}E-1=0.971 \\
E-2=()\end{array}$ & $\begin{array}{l}E-1=0.891 \\
E-2=()\end{array}$ & $\begin{array}{l}E-1=0.693 \\
E-2=()\end{array}$ \\
\hline Exon score & $\begin{array}{l}E-1=50.17 \\
E-2=1.05\end{array}$ & $\begin{array}{l}E-1=41.07 \\
E-2=-1.75\end{array}$ & $\begin{array}{l}E-1=40.44 \\
E-2=1.05\end{array}$ & $\begin{array}{l}\text { E-1 }=23.84 \\
\text { E-2 }=-0.45\end{array}$ & $\begin{array}{l}E-1=46.62 \\
E-2=1.05\end{array}$ \\
\hline
\end{tabular}


Intrepretation Of Data- The above data provides Gene structural information of the genes encoded by Ebola virus proteins. The data represented in the above table shows different terminologies involving gene structure i.e. Exon Number, Type of Exon [Init = Initial exon (ATG to 5'splice site); Intr = Internal exon (3'splice site to 5'splice site); Term $=$ Terminal exon ( 3 ' splice site to stop codon); Sngl = Single exon gene (ATG to stop); Prom = Promoter $($ TATA box/ initiation site); Ply A = poly A signal (consensus: AATAAA)]. We also study DNA strand i.e. $(+)=$ input strand and $(-)=$ negative strand. We also studied beginning of the exon / signal, end of the exon/signal, Length of exon, Reading frame, Net phase of exon, Initial signal/3' splice site score, Termination signal $/ 5$ ' splice site score, Coding region score, probability of exon along with exon score.

\section{CONCLUSION}

This three module study help us to know different angles i.e; the Extinction coefficient estimations of proteins help us to distinguish the adjustment in light collecting proficiency and surface inclusion esteem with submersion solvent, Immersion time and drenching focus in the protein. It is likewise used to ponder the effect of dissolvable to control the adsorption kinetics. This is utilized to characterize the scope of wavelength where the light has its greatest profundity of infiltration in tissue. This is the inherent property of various species so it is utilized to separate between the molecules. Instability record clarifies the steady property of protein. Aliphatic file estimates the dissolvability of focused proteins. We even assessed whether the protein is hydrophobic/hydrophilic dependent on the amazing normal of hydrophaticity values. we can anticipate the protein structure, Function and developmental history of groupings and its utilization structure superposition programs and phylogenetic examination programmes. By the quality basic data we can discover infection seriousness and foresee quality structure to explore function, expression level, disease, mutation. By this quality basic investigation we can avoid the sickness by postponement of occurance of ailment.

\section{REFERENCES}

1.Multiple sequence alignment: a methodology for protein identification 2015 (Srinivasa Rao V.*1, Das S. K.2, Nageswara Rao K.3 and Kusuma Kumari E.4)

2. Protein Identification and Analysis Tools on the ExPASy Server 1998 (Elisabeth Gasteiger, Christine Hoogland, Alexandre Gattiker,Séverine Duvaud, Marc R. Wilkins, Ron D. Appel, and Amos Bairoch)

3.Ebolavirus disease by CDC/Dr F. A. Murphy 2003(World health organisation-western pacific region)

4.Genome sequence analysis of Ebola virus in clinical samples from three british healthcare workers, August 2014 to March 2015(A Bell, K Lewandowski, R Myers, D Woolridge, E Aarons, A simpson, R Vipond, M Jacobs, S Gharbia, M Zambon.
5. IN SILICO approach of structure prediction and funtional characterization of Zaire Ebola and identification of binding site for drug development 2016 (Md. Jahirul Islam, Kaniz Fatima, Pipasha Biswas2008 Department of Biochemistry and Biotechnology; University Of Science And Technology, Chittagong )

6. Advance protein alingments based on sequence, structure and hydropathy profiles 2018 The paradigm of viral polymerase enzyme (Alexandros Armaos , Dimitrios Vlachakis, Sophia Kossida)

7. Extiction coefficient- (2007)A guide to understanding extinction coefficient, with emphasis spectrophotometric determination of protein concentration

8. Ebola virus comparative genomics (1999)(Se-Ran Jun; Michael R.Leuze; and David W. Ussery)

9. Ebolaviruses New Roles For Old Proteins (2013)(Diegocantoni, Jeremy S. Rossman-School of Biosciences, University Of Kent, Canterbury,UK) 10. Ebola Virus: (2012) Identification of Virion Structural Proteins By Michael P. Kiley; Russell L. Ragnery and Karl M. Johnson (Special pathogens branch, Virology Divison , Bureau Of Laboratories, Centre for disease control, Public Health Service, US Health, Education and Welfare, Atlanta, Georgia 30333) 1. 11.Bermejo M, Rodriguez-Teijeiro JD, Illera G, Barroso A, Vilà C, Walsh PD. Ebola outbreak killed 5000 gorillas. Science 2006;314:1564. 2.

12Chepurnov AA, Bakulina LF, Dadaeva AA, Ustinova EN, Chepurnova TS, Baker JR Jr. Inactivation of Ebola virus 